FABRICIO ALONSO RICHMOND NAVARRO

Análise da possível expansão internacional de empresas brasileiras de real estate residencial para o mercado costarriquenho, uma abordagem SWOT

\footnotetext{
Dissertação apresentada à Escola Politécnica da Universidade de São Paulo para obtenção do título de Mestre em Ciências, Programa de Pós-Graduação em Engenharia Civil
} 
FABRICIO ALONSO RICHMOND NAVARRO

Análise da possível expansão internacional de empresas brasileiras de real estate residencial para o mercado costarriquenho, uma abordagem SWOT

Dissertação apresentada à Escola Politécnica da Universidade de São Paulo para obtenção do título de Mestre em Ciências, Programa de Pós-Graduação em Engenharia Civil

Área de Concentração: Engenharia de Construção Civil e Urbana

Orientador: Prof. Dr. Claudio Tavares de Alencar

São Paulo 
Este exemplar foi revisado e corrigido em relação à versão original, sob responsabilidade única do autor e com a anuência de seu orientador.

São Paulo, de maio de 2015.

Assinatura do autor

Assinatura do orientador

Catalogação-na-publicação

Richmond Navarro, Fabricio Alonso

Análise da possível expansão internacional de empresas

brasileiras de real estate residencial para o mercado costarrique-nho, uma abordagem SWOT/ F.A. Richmond Navarro. - versão corr. -- São Paulo, 2015.

$146 \mathrm{p}$.

Dissertação (Mestrado) - Escola Politécnica da Universidade de São Paulo. Departamento de Engenharia de Construção Civil.

1.Empresas (Crescimento e desenvolvimento) - Brasil 2.Real estate 3.Análise SWOT I.Universidade de São Paulo. Escola Politécnica. Departa-mento de Engenharia de Construção Civil II.t. 
Dedicado a mi madre y padre con los que cuento en cualquier situación. 


\section{AGRADECIMENTOS}

Em primeiro lugar a Deus, nosso Senhor, por permitir esta incrível oportunidade e dar as forças para concluir com sucesso este projeto.

Em segundo lugar a minha família, que sempre me apoiou incentivando-me a dar meu melhor esforço.

Também quero agradecer a meu professor orientador Dr. Claudio Alencar, que sempre me guiou na busca da qualidade durante todo o trabalho, além de ter muita paciência nos primeiros estágios deste.

Aos amigos do programa de bolsas da OEA, do Projete Liberdade, da LARES (especialmente Renata), da Sala Asteroide e quem me recebeu em seu lar Guido, Fabio, Patrícia, Julia, Alessandra, Célio, Winnie, Pedrita, Sidney, Lautaro e Abraham.

Ao Programa de Aliança para a Educação e Capacitação: a Organização de Estados Americanos e à Associação Grupo Coimbra de Universidades Brasileiras (PAEC OEA/GCUB) pela bolsa de estudo e a iniciativa neste tipo de proposta para 0 desenvolvimento dos países da América.

Ao Ministério da Ciência, Tecnologia e Telecomunicações (MICITT) e ao Conselho Nacional para Pesquisas Científicas e Tecnológicas (CONICIT) da Costa Rica, pelo apoio econômico recebido para o desenvolvimento deste projeto.

Agradeço também aos profissionais e empresas que aceitaram colaborar com o questionário da pesquisa. 
"Las complicaciones surgen, se consideran y se superan"

J.D. 


\section{RESUMO}

Devido ao crescimento e à experiência adquirida pelas empresas brasileiras de real estate residencial nos últimos anos, e às características próprias desse setor, os mercados internacionais poderiam ser considerados como possíveis alvos para essas empresas. Por exemplo, no mercado residencial costarriquenho, incentivos para projetos residenciais de alta densidade populacional, reformas nos processos para a obtenção dos alvarás de construção e mudanças demográficas e culturais, parecem propiciar um ambiente favorável para empresas dessa indústria. Portanto, o objetivo do presente trabalho é estudar uma possível expansão geográfica de empresas brasileiras de real estate no mercado residencial costarriquenho, a partir da estruturação de uma análise de abordagem SWOT dos elementos necessários para tal incursão. Para isso, realizou-se uma revisão bibliográfica na busca dos elementos estratégicos do ambiente interno de empresas de real estate residencial que devem ser considerados para processos de internacionalização, identificando-se 12 forças e 10 fraquezas desta revisão. Ademais, analisou-se: o mercado residencial; a macroeconomia, e as conjunturas político-legais e socioculturais da Costa Rica, na procura de fatores que devem ser tomados em conta por parte de empresas de real estate ao ingressar nesse país, distinguindo-se 24 oportunidades e 20 ameaças dessa análise. Para complementar o estudo, foi avaliada a atratividade do mercado residencial costarriquenho para receber investimentos por onze importantes empresas do setor de real estate residencial brasileiro, por meio de um questionário estruturado com os elementos identificados na primeira parte do trabalho. Os resultados mostraram que, no momento da avaliação, as empresas entrevistadas deram maior atenção ao tamanho do mercado e às características do sistema financeiro para o setor residencial, e identificaram a carência do conhecimento local e sua cultura empresarial, como os elementos que dificultariam sua internacionalização. Conclui-se sobre a possível internacionalização de empresas brasileiras de real estate residencial para o mercado da Costa Rica, que elementos desde uma perspectiva econômica-racional e principalmente contingencial definem essa estratégia, não sendo viável nem vantajoso idealizar um processo de internacionalização nesse mercado, devido às atuais condições de seus mercados locais e aos elementos do ambiente interno que várias dessas empresas apresentam.

Palavra-chave: SWOT, empresas, expansão, internacional, residencial, real estate. 


\begin{abstract}
Due to the growth and experience acquired by the residential real estate Brazilian companies in recent years, and the particular characteristics of this sector, international markets could be considered as possible targets for these companies. For example, in Costa Rican residential market, incentives for residential projects of high population density, reforms in the paperwork required to obtain building permits and demographic and cultural changes, seem to provide a favorable environment for this kind of firm. Therefore, the aim of this work is to study a possible geographic expansion of Brazilian real estate companies into Costa Rica's residential market, based on a SWOT analysis. Therefore, firstly, a research on international business and business strategy literature was performed to find the internal elements involved in the processes of internationalization for this kind of companies. Then, the residential market characteristics, macroeconomic, and the political-legal and sociocultural contexts of Costa Rica were reviewed in order to distinguish the factors that should be taken into account by real estate companies when entering this market. In total, 12 strengths and 10 weaknesses were identified by the internal analysis, and 24 opportunities and 20 threats by external analysis. To complement the study, the attractiveness of the Costa Rican residential market to receive investment was assessed by eleven important Brazilian real estate residential companies, utilizing a designed questionnaire with the elements identified in the first part of this work. The results showed that, at the time of the assessment, the interviewed companies gave more attention to market size and characteristics of the financial system for the residential sector, and identified the lack of local knowledge and its corporate culture, as elements that hinder their internationalization. In conclusion, the possible internationalization of real estate Brazilian companies is defined by economic-rational elements, but mainly by contingent elements such as the current conditions of their local markets and the internal elements shown by many of the interviewed companies. On account of all that has been discussed so far, internationalization is not feasible or advantageous for these specific companies.
\end{abstract}

Keywords: SWOT, companies, expansion, international, residential, real estate. 


\section{LISTA DE FIGURAS}

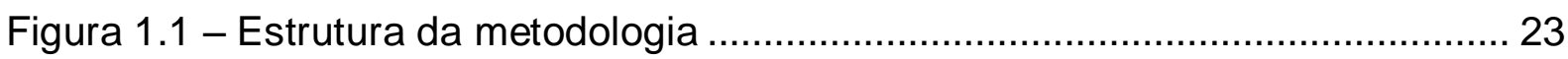

Figura 2.1 - Estágios de envolvimento internacional ........................................... 31

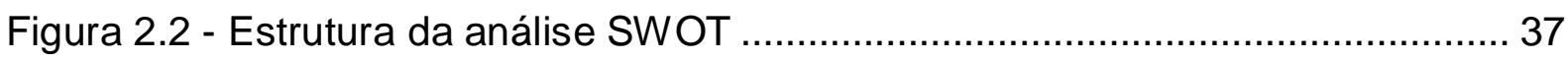

Figura 2.3 - Decisões no Processo de Formulação de Estratégias ......................... 38

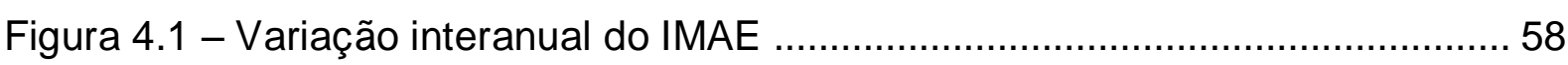

Figura 4.2 - Regime de câmbio (preço de compra) 2013-2014 ............................... 61

Figura 4.3 - Localização da Costa Rica.............................................................. 71

Figura 4.4 - Localização da GAM na Costa Rica ................................................. 72

Figura 4.5 - Propriedade das moradias na Costa Rica ENAHO 2013 ..................... 75

Figura 4.6 - Estado físico das moradias na Costa Rica ENAHO 2013 .................... 75

Figura 4.7 - Frequência de quantidades de pessoas por lar ................................. 79

Figura 4.8 - Percentagem de moradias ocupadas, período 2010-2013 ENAHO (só

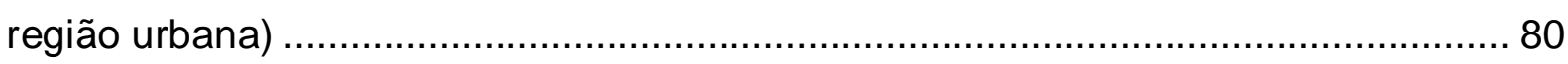

Figura 4.9 - Média anual das taxas de referência para juros no Brasil e na Costa

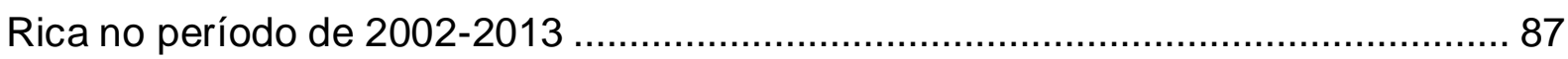

Figura 4.10 - Taxa de juros para financiamento imobiliário Costa Rica e Brasil ...... 88 Figura 4.11 - Colocação anual do total de créditos para moradia no SFN em moeda local e número de moradias com alvará de construção 90

Figura 4.12 - Variação percentual da economia e do setor de construção no período

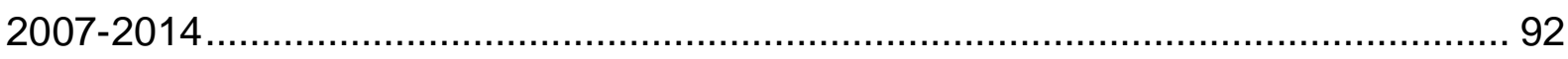

Figura 4.13 - Metros quadrados aprovados em permissões de construção ............. 93

Figura 4.14 - Densidade de projetos por número de dormitórios ............................. 96

Figura 5.1 - Interesse em estudar o mercado da Costa Rica ................................. 105

Figura 5.2 - Qualidade da informação ............................................................ 105

Figura 5.3 - Atratividade do mercado costarriquenho .......................................... 106

Figura 5.4 - SWOT das empresas entrevistadas .............................................. 111 


\section{LISTA DE TABELAS}

Tabela 2.1 - Vieses do SWOT 39

Tabela 4.1 - PIB e taxas de variação do período 2007-2013 57

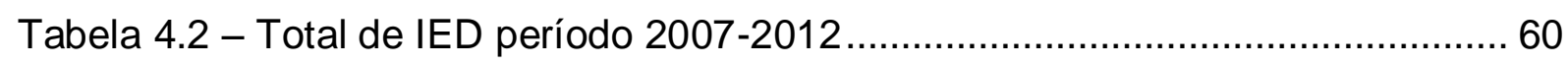

Tabela 4.3 - Taxa de desemprego aberto, período 2006-2013 ……........................ 60

Tabela 4.4 - Segmentos de renda segundo ENAHO 2013 ...................................... 73

Tabela 4.5 - Divisão dos lares por renda.......................................................... 74

Tabela 4.6 - Desocupação das moradias na Costa Rica censo 2011 ...................... 77

Tabela 4.7 - Dados dos habitantes da Costa Rica segundo os Censos 1984, 2000 e 2011 78

Tabela 4.8 - Exemplos de vários planos de financiamento de moradia. 86 Tabela 4.9 - Número de moradia para 2013 em relação aos metros quadrados de construção 91

Tabela 4.10 - Projetos de uso misto de relevância na Costa Rica. 94

Tabela 4.11 - Ação da concorrência na GAM 95

Tabela 4.12 - Facilidades dos projetos imobiliários: piscina e estacionamento .97 Tabela 5.1 - Importância das oportunidades e ameaças na tomada de decisões . 107 Tabela 5.2 - Valoração das oportunidades e ameaças do mercado costarriquenho 


\section{LISTA DE ABREVIATURAS E SIGLAS}

\begin{tabular}{ll} 
BANHVI & Banco Hipotecário da Moradia \\
BCB & Banco Central do Brasil \\
BCCR & Banco Central da Costa Rica \\
BCR & Banco da Costa Rica \\
BNCR & Banco Nacional da Costa Rica \\
CAS & Coeficientes de Aproveitamento do Solo \\
CCDI & Camargo Corrêa Desenvolvimento Imobiliário \\
DHR & Déficit Habitacional Real \\
DHT & Déficit Habitacional Tradicional \\
DQR & Déficit Qualitativo Real \\
DQT & Déficit Qualitativo Tradicional \\
EHPM & Enquete de Lares de Propósito Múltiplos \\
ENAHO & Enquete Nacional de Lares \\
EPUSP & Escola Politécnica da Universidade de São Paulo \\
FII & Fundo de Investimento Imobiliário \\
FN & Faltante Natural \\
FOFA & Forças, Fraquezas, Oportunidades e Ameaças \\
FUPROVI & Fundação Promotora de Moradia \\
GAM & Grande Área Metropolitana \\
IED & Investimento Estrangeiro Direto \\
IMAE & Índice Mensal de Atividade Econômica \\
INEC & Instituto Nacional de Estatística e Censo \\
INVU & Instituto Nacional de Moradia e Urbanismo \\
IPC & Índice de Preços ao Consumidor \\
MEIC & Ministério de Economia, Indústria e Comercio \\
MERCOSUL & Mercado Comum do Sul \\
MID & Moradia Individual Desocupada \\
MIO & Moradia Individual Ocupada \\
MIVAH & Ministério de Moradia e Assentamentos Humanos \\
PEN & Programa Estado da Nação \\
PIB & Produto Interno Bruto \\
\hline FA &
\end{tabular}




$\begin{array}{ll}\text { PNOT } & \text { Política Nacional de Ordenamento Territorial 2012 a } 2040 \\ \text { POT/GAM } & \text { Plano de Ordenamento Territorial da GAM 2011-2030 } \\ \text { PPP } & \text { Parcerias Público-Privadas } \\ \text { SELIC } & \text { Sistema Especial de Liquidação e de Custódia } \\ \text { SFN } & \text { Sistema Financeiro Nacional } \\ \text { SUGEF } & \text { Superintendência Geral de Entidades Financeiras } \\ \text { SWOT } & \text { Siglas em inglês de Strengths, Weakness, Opportunities e Threats } \\ \text { TBP } & \text { Taxa Básica Passiva } \\ \text { TPR } & \text { Taxa Prime Rate }\end{array}$




\section{SUMÁRIO}

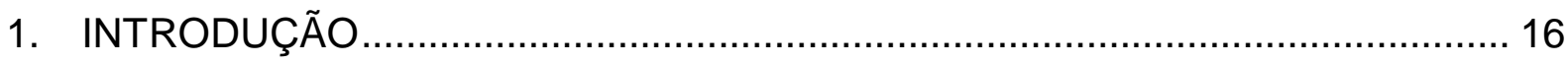

1.1 Apresentação do tema............................................................................ 16

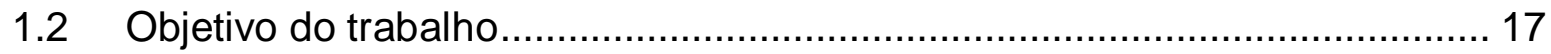

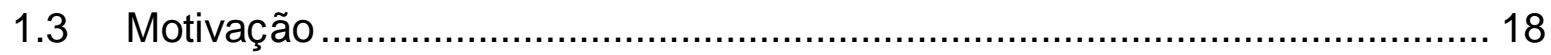

1.4 Contribuição acadêmica ......................................................................... 19

1.5 Metodologia

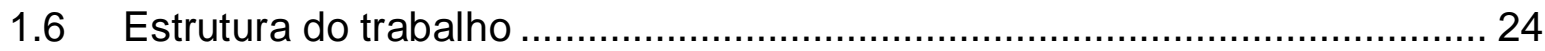

2. INTERNACIONALIZAÇÃO DE EMPRESAS DE REAL ESTATE RESIDENCIAL 25

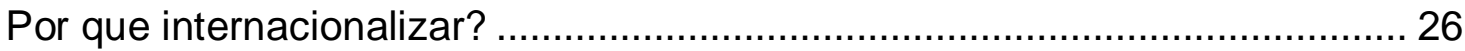

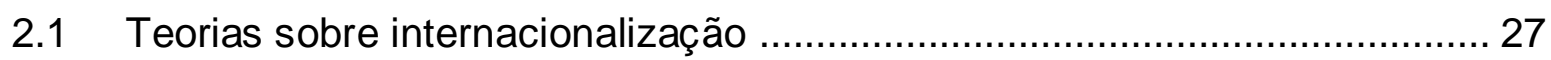

2.1.1 Perspectiva econômica................................................................ 27

2.1.2 Processo organizacional ou comportamental ..................................... 29

Modelo de Uppsala ............................................................................. 30

2.1.3 Empresas "Born Global" ............................................................... 32

2.2 Empresas de real estate residencial em processos de internacionalização 32

2.2.1 Expansão geográfica das empresas brasileiras de real estate residencial

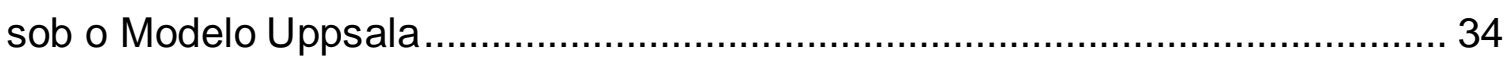

2.2.2 Formulação de estratégias de expansão internacional com uma

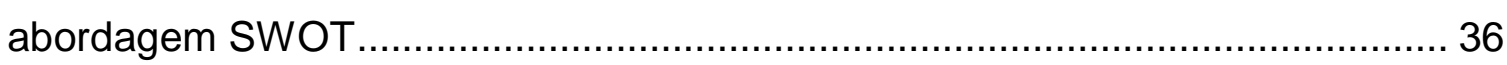

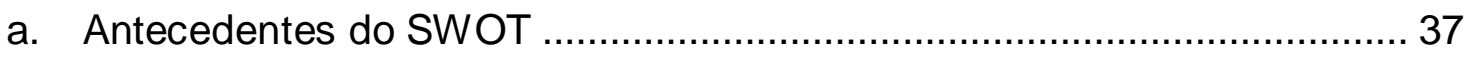

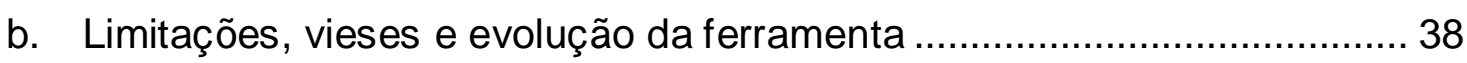

3. ANÁLISE DO AMBIENTE INTERNO DE EMPRESAS DE REAL ESTATE

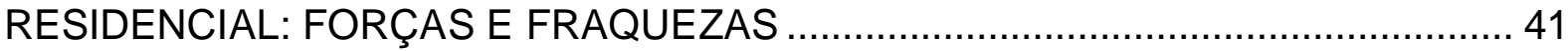

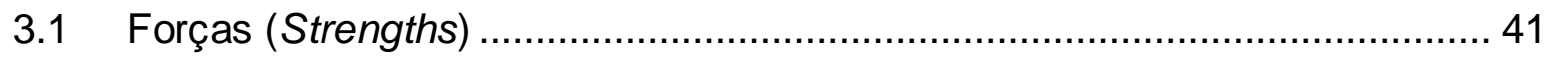

3.1.1 Competências essenciais para estratégias de internacionalização....... 42

3.1.2 Competências essenciais das empresas de real estate ....................... 45 


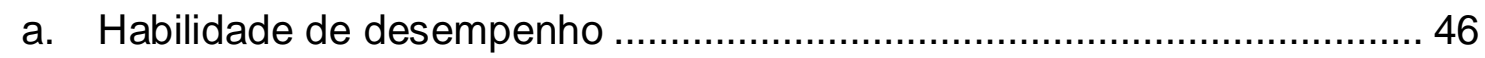

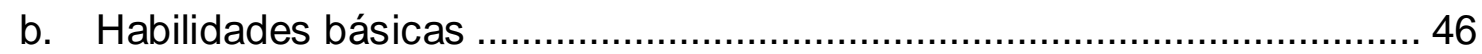

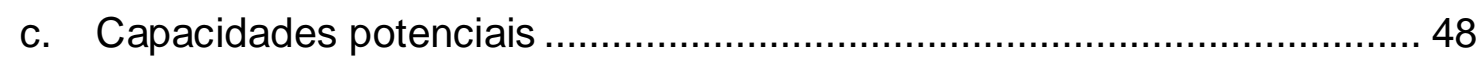

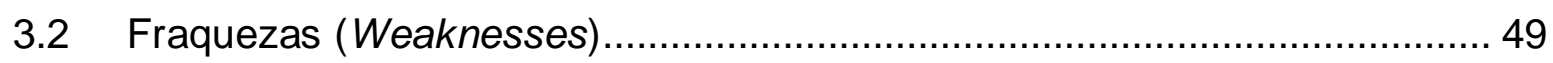

3.2.1 Em mercados internacionais ........................................................... 49

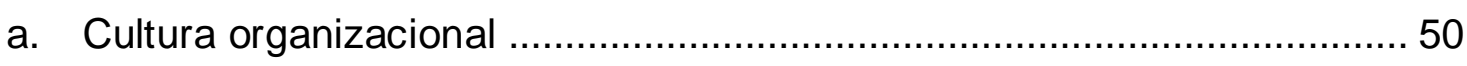

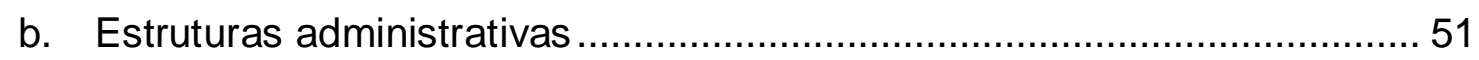

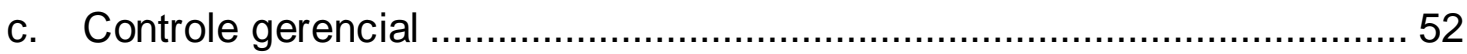

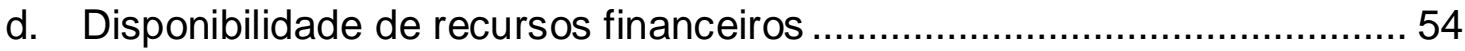

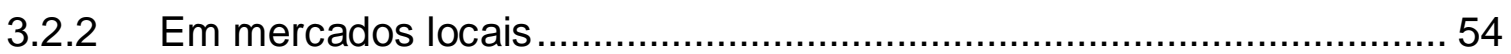

4. ANÁLISE DO MERCADO RESIDENCIAL COSTARRIQUENHO: OPORTUNIDADES E AMEAÇAS (OPPORTUNITIES AND THREATS).................. 56

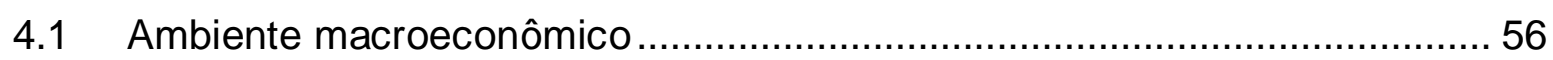

4.1.1 Investimento Estrangeiro Direto ……………...................................... 59

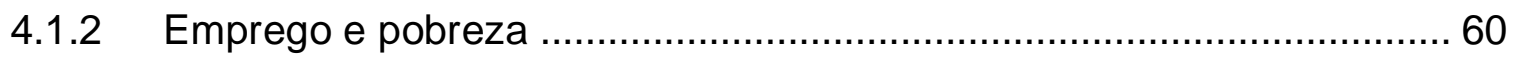

4.1.3 Regime de câmbio: dólar - colóns ....................................................... 61

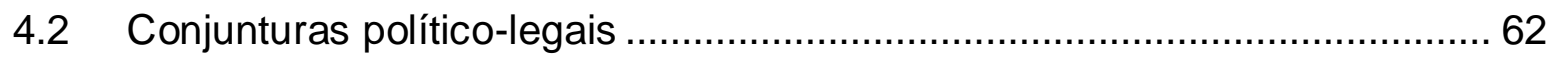

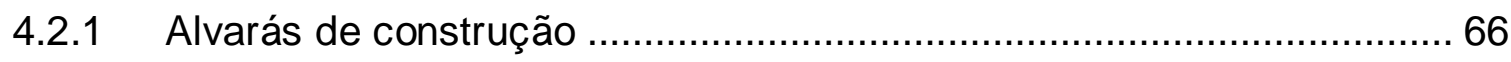

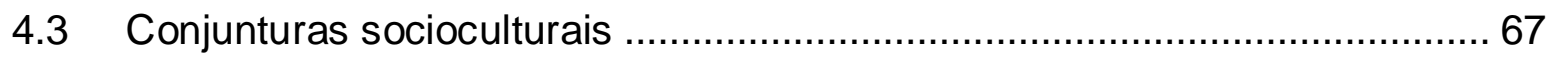

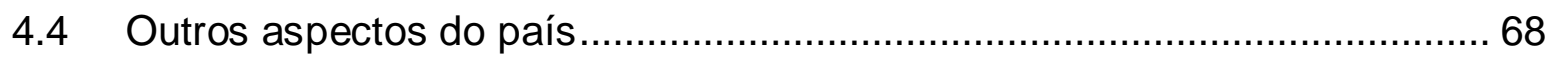

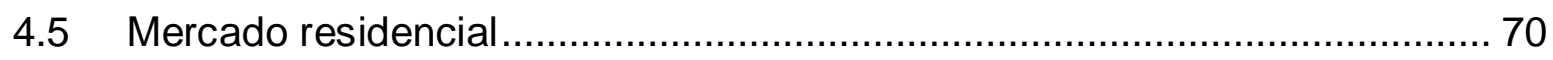

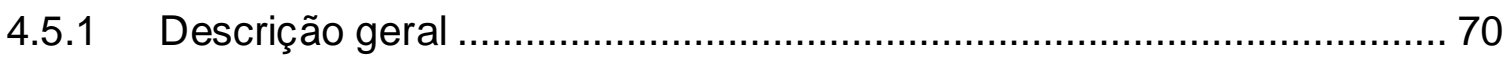

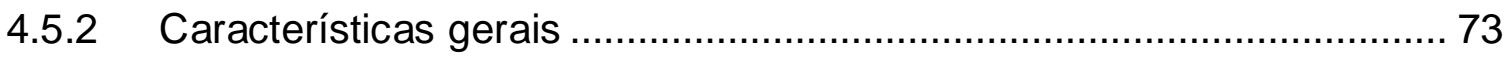

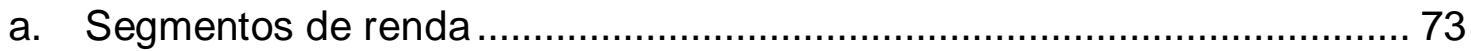

b. Fatores de propriedade e do estado das moradias ................................. 75

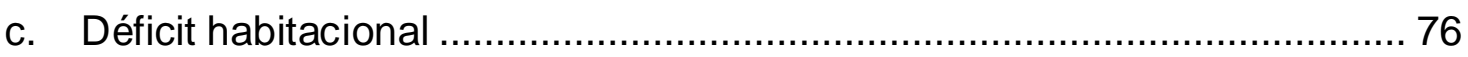

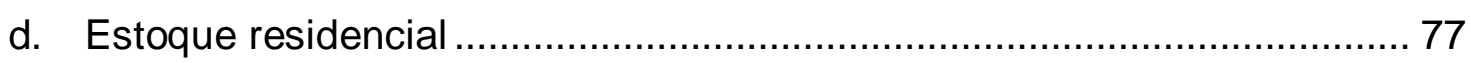

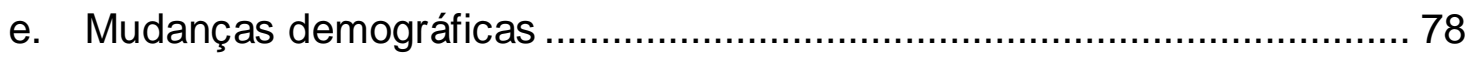

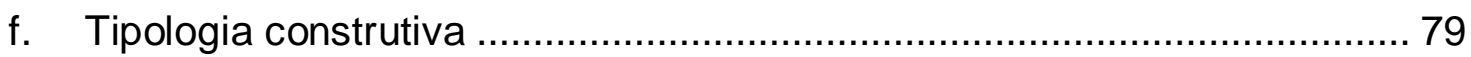

g. Estimativa da demanda potencial da GAM ........................................... 80 


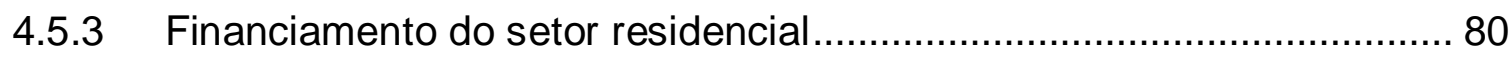

a. Linhas de crédito para empresas de real estate ..................................... 83

b. Linhas de crédito para público ou pessoas físicas ................................... 85

4.5.4 Nível de absorção de mercado......................................................... 90

4.5.5 Ação da concorrência e oferta competitiva .......................................... 91

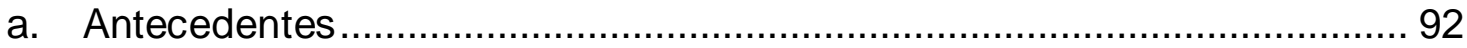

b. Oferta competitiva da GAM............................................................... 94

5. APLICAÇÃO DA ANÁLISE A VÁRIAS EMPRESAS BRASILEIRAS DE REAL

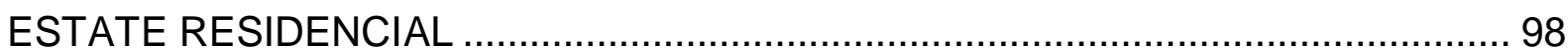

5.1 Sínteses das oportunidades e ameaças do mercado residencial costarriquenho 98

5.2 Sínteses das forças e fraquezas das empresas de real estate residencial . 99

5.3 Descrição do questionário dirigido às empresas de real estate 100

5.4 Empresas entrevistadas ................................................................... 100

5.5 Principais resultados das entrevistas ..................................................... 104

5.5.1 Interesse no mercado da Costa Rica .................................................. 104

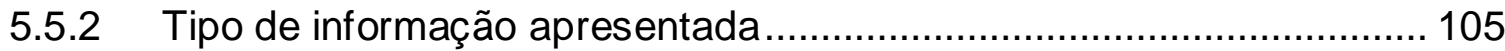

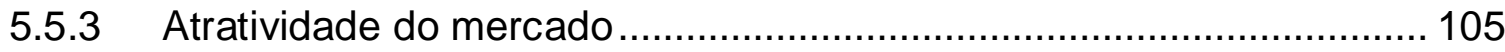

5.5.4 Importância das oportunidades e ameaças do mercado ...................... 106

5.5.5 Forças e fraquezas das empresas ……………………………...... 109

5.5.6 Outras observações ..................................................................... 110

5.6 SWOT das empresas entrevistadas .................................................. 111

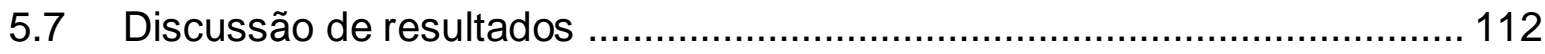

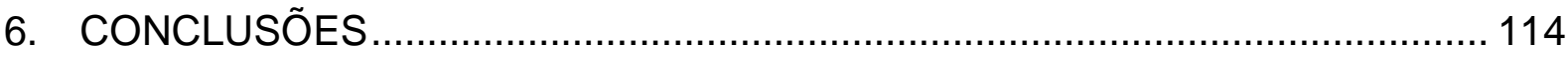

6.1 Considerações finais sobre o mercado residencial costarriquenho ...........115

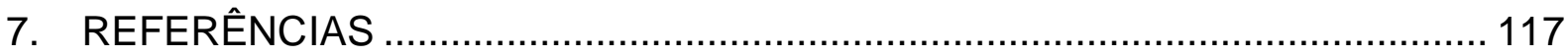

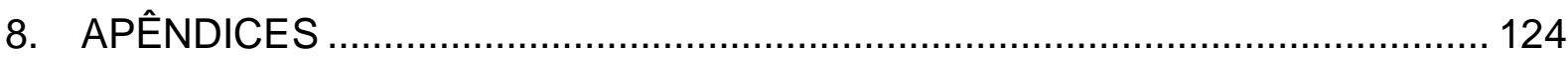


8.1 APENDICE A - Documento para a entrevista às empresas de real estate residencial

8.2 APENDICE B - Documento para a entrevista às empresas de real estate residencial Resultados das entrevistas às empresas brasileiras de real estate residencial: forças e ameaças

9. ANEXO

9.1 ANEXO A - Empresas de capital aberto 141 


\section{INTRODUÇÃO}

\subsection{Apresentação do tema}

$\mathrm{Na}$ atual economia globalizada é possível que empresas dos diversos setores industriais atinjam novos mercados, saindo de suas fronteiras habituais de atuação em uma perspectiva internacional. Mesmo que as empresas de manufatura tenham uma maior tradição nessa abertura, firmas de serviços vêm se desenvolvendo rapidamente com uma expressiva participação no comércio internacional, segundo afirmam Florentino e Gomes (2009).

Assim, empresas como as de real estate podem encontrar uma opção de crescimento nesse tipo de estratégia, motivadas por condições externas, como mercados mais lucrativos ou de maior tamanho (KOTLER, 2000), até situações internas, ligadas a questões de gerenciamento e visão empresarial, produto do empreendedorismo internacional (NUMMELA; SAARENKETO; PUUMALAINEN, 2004).

Tendo em vista o crescimento e a experiência adquirida pelas empresas do setor residencial brasileiro nos últimos anos, e as vantagens e facilidades próprias desse setor, que permite o ingresso de novas companhias, sem fortes barreiras de entrada (ROCHA LIMA, 1994), os mercados residenciais internacionais poderiam ser considerados como possíveis alvos para essas empresas.

Por exemplo, na Costa Rica se reconhecem políticas de incentivos para projetos residenciais de alta densidade populacional, reformas na redução do tempo e dos processos para a obtenção dos alvarás de construção, e mudanças demográficas e culturais, que poderiam ser favoráveis para os negócios no setor residencial (BARRANTES, 2012; MINISTÉRIO DE MORADIA E ASSENTAMENTOS HUMANOS, 2012a; 2012b).

A essas condições se somam as características intrínsecas do mercado residencial costarriquenho, a saber: dimensão, déficit habitacional, cultura instalada, nível de 
absorção de mercado, oferta competitiva e características das linhas de financiamento, que poderiam ser estudadas pelas empresas brasileiras na procura de elementos atrativos para uma possível atuação.

Com a completa análise de todo o conjunto de informações, empresas brasileiras de real estate experientes no segmento residencial poderiam concluir sobre sua possível participação nesse mercado, avaliando as oportunidades e ameaças do mercado costarriquenho e seu perfil de competências para a estratégia em questão.

Além disso, a discussão de uma estratégia desse tipo se torna relevante pelo fato de que, em anos anteriores (2007 a 2010), algumas das maiores incorporadoras brasileiras de real estate residencial se diversificaram geograficamente pelo território nacional de maneira precipitada, encontrando na aplicação dessa estratégia grandes dificuldades em obter sucesso ao atingir suas metas, mostrando prejuízos nos resultados dos balanços de 2011 (ROCHA LIMA, 2012).

Portanto, uma análise prévia à possível internacionalização de empresas brasileiras do setor residencial poderia servir de referência para um planejamento e tomada de decisões sobre a estratégia em questão, nas empresas desse setor no futuro.

\subsection{Objetivo do trabalho}

O objetivo principal do presente trabalho é estudar uma possível expansão geográfica internacional de empresas brasileiras de real estate no mercado residencial costarriquenho, a partir da estruturação de uma análise de abordagem SWOT ${ }^{1}$ dos elementos necessários para essa estratégia.

Portanto, o objetivo contempla o reconhecimento das principais forças e fraquezas de empresas de real estate residencial, em processo de expansão internacional, estudando suas competências essenciais e características de sua estrutura organizacional e cultura empresarial.

\footnotetext{
${ }^{1}$ SWOT siglas em inglês de Strengths, Weakness, Opportunities e Threats, em português: Forças, Fraquezas, Oportunidades e Ameaças (FOFA).
} 
Além disso, comporta distinguir as oportunidades e ameaças do mercado residencial costarriquenho, com a análise dos fatores econômicos e das principais conjunturas político-legais e socioculturais do país que possuem influência nesse mercado, como também suas características próprias, a saber: dimensão, cultura instalada, linhas de financiamento, nível de absorção de mercado e oferta competitiva.

Complementando, objetivou-se avaliar a atratividade do mercado residencial costarriquenho para receber investimentos de importantes empresas brasileiras do setor de real estate residencial.

\subsection{Motivação}

O desenvolvimento desta dissertação foi motivado por dois fatos observados pelo autor em dois países diferentes.

O primeiro fato se deve à impressão que deixaram as dinâmicas do mercado residencial em São Paulo (Brasil), com uma grande quantidade de lançamentos e empreendimentos para a maior parte dos segmentos de renda. Isso proporciona uma variedade de produtos com características diferentes, para serem avaliados pelo consumidor de acordo com suas condições econômicas e suas necessidades, gerando dinâmicas de competência entre as empresas, onde o beneficiado é o consumidor.

Essa situação contrastou com a realidade do mercado residencial costarriquenho (segundo fato), no qual empreendimentos de tipo residencial em condomínio nos centros das principais cidades ou a seu redor, estão direcionados principalmente para as classes altas (como será mostrado no final do capítulo 4).

Essa carência de produtos para a classe média, obriga a muitas famílias a procurar terrenos fora dos centros de maior atividade econômica, para a construção de casas unifamiliares, criando assim cidades-dormitório, o espalhamento da mancha urbana 
e o uso inadequado dos recursos naturais, impactando negativamente tanto no meio ambiente como na qualidade de vida dos cidadãos.

Portanto, essas situações motivaram o autor, que tem trabalhado com investidores estrangeiros e empresas internacionais, a estudar a possível internacionalização das empresas brasileiras do setor residencial, visando o mercado costarriquenho, atividade que fomentaria o desenvolvimento de ambas as economias desses países.

\subsection{Contribuição acadêmica}

As atuais economias globalizadas, os modernos sistemas de informação e as características intrínsecas do setor residencial propiciam um ambiente favorável para que empresas de real estate saiam de suas fronteiras habituais de atuação para uma perspectiva internacional. Porém, escassa é a literatura encontrada deste fenômeno. Em sua maioria, encontraram-se estudos de caso de empresas que, pelo tipo de atividade que realizam, podem mudar seu envolvimento no novo mercado, aumentando sua penetração neste com diferentes estágios, seja exportação de produtos, venda de licenciamentos ou franquias, até níveis mais superiores, como pode ser a instalação de subsidiárias (OSLAND; TAYLOR; ZOU, 2001).

Também, se encontrou literatura e pesquisas da internacionalização de empresas do setor de construção civil, especificamente de construção pesada (VARGAS, 2008; SCHERER; GOMES; KRUGLIANSKAS, 2009; JUNG et al., 2010). Mas essa literatura não trata certas considerações que deveria ter uma empresa com atuação na área residencial, a qual precisa estar mais consciente do contexto local (questões mercadológicas, técnicas e legais) para a formatação de seus produtos, para agregar algum diferencial a seus empreendimentos e atender os desejos e anseios dos múltiplos compradores.

Em um estudo mais aprofundado da literatura específica da área de real estate, o tema da internacionalização apresenta dois focos de importante peso. O primeiro trata da avaliação dos principais riscos e as oportunidades de rentabilidade sob a ótica dos investidores, quando estes diversificam seu portfólio de investimento em 
mercados internacionais por vias como a compra de títulos ou ações (BARDHAN; KROLL, 2007; ROCHA LIMA; ALENCAR, 2008). O segundo foco trata da internacionalização de serviços de corretagem de propriedades (ALON; BIAN, 2005; BARDHAN; KROLL, 2007).

Portanto, o presente trabalho utiliza um caso específico, como são as empresas brasileiras de real estate visando o mercado residencial da Costa Rica, para estruturar os elementos estratégicos que devem ser avaliados num processo de internacionalização, a partir de uma análise de abordagem SWOT. Almeja-se, assim, alcançar um processo atípico para este tipo de empresas dentro da temática do planejamento estratégico.

\subsection{Metodologia}

Para cumprir os objetivos estabelecidos, estruturou-se a metodologia apresentada na Figura 1.1:

\section{-Etapa 1}

Nesta etapa elaborou-se uma análise de abordagem SWOT de elementos internos e externos, relativos à possível expansão geográfica internacional de empresas brasileiras de real estate no mercado residencial costarriquenho.

O problema divide-se em duas partes, a primeira parte consta de uma revisão bibliográfica que tem por objetivo procurar no ambiente interno de empresas de real estate residencial as forças e fraquezas para esse tipo de estratégia. Para isso, utilizou-se literatura sobre internacionalização de empresas (HILAL; HEMAIS, 2003; URBAN; FLEURY, 2005; BARDHAN; KROLL, 2007; VARGAS, 2008; FLORENTINO; GOMES 2009), da qual foram resgatados os elementos estratégicos que compartem as empresas dos casos de estudo, com as empresas de real estate residencial.

Além disso, utilizou-se literatura própria de real estate (GIBLER et al., 2002; MANNING; EPLEY, 2006; LINJIE, 2011; COMITÊ DE MERCADO EPUSP; 2012), para reconhecer as competências essenciais intrínsecas dessas empresas, além 
dos elementos estratégicos, dentro da estrutura organizacional e cultura empresarial, necessários para entrar em novos mercados.

A segunda parte consta de uma análise do ambiente externo, o qual distingue as oportunidades e ameaças para empresas de real estate residencial, considerando o ambiente macroeconômico e as principais conjunturas político-legais e socioculturais da Costa Rica:

- O ambiente macroeconômico do país foi analisado por meio de indicadores, tais como: Produto Interno Bruto (PIB), Investimento Externo Direto (IED), Índice Mensal de Atividade Econômica (IMAE), Índice de Preços ao Consumidor (IPC), regime de câmbio da moeda local relativo ao dólar, emprego e pobreza.

- Na parte político-legal, foram analisadas políticas, leis e decretos que impactam o setor residencial, urbanístico e de planejamento urbano. Elementos que, de alguma forma, incentivam ou limitam os assentamentos humanos e são de suma importância às empresas, já que eles ditam 0 percurso e o desenvolvimento que o país deseja obter.

- Por último, foram avaliados os elementos socioculturais, tais como: língua, costumes, práticas de negócios, nível e conteúdo educacional, os quais variam de país a país e influenciam o desempenho das empresas e suas estratégias de atuação (e.g. na formação de alianças estratégicas) (URBAN; FLEURY, 2005; FLORENTINO; GOMES, 2009).

A informação para a descrição desse ambiente foi levantada dos dados, relatórios e documentos das principais instituições públicas e privadas que estudam o setor residencial, de construção e econômico da Costa Rica. Para a descrição do desenvolvimento humano do país em aspectos políticos, sociais e econômicos, 0 trabalho utiliza o relatório anual do "Programa Estado da Nação" (PEN).

Depois de estudar essas condições do país, a análise do ambiente externo distingue as oportunidades e ameaças das características próprias do mercado residencial costarriquenho, a saber: generalidades, dimensão, cultura instalada e taxa de crescimento da população. Ademais, de elementos mais relativos a uma ordem 
estratégica como: sistemas de financiamento, nível de absorção de mercado e oferta competitiva.

Para a descrição das características do mercado residencial foram utilizados como principais insumos o "X Censo Nacional de População e VI de Moradia do ano de 2011" e censos anteriores, além da "Enquete Nacional de Lares" (ENAHO) ${ }^{2}$ de 2013 e anteriores. A análise foi complementada com informação de periódicos de circulação nacional, que mostram as condições atuais do mercado residencial costarriquenho e a ação da concorrência.

\section{-Etapa 2:}

Nesta etapa avaliou-se a atratividade do mercado residencial costarriquenho como alvo para investimento de empresas brasileiras. Formatou-se um questionário com base nas informações geradas na análise da etapa anterior, o qual foi aplicado em uma entrevista a onze empresas que atuam nos maiores mercados residenciais do Brasil.

O questionário consta de três partes:

i. A apresentação das oportunidades e ameaças do mercado costarriquenho, estas subdivididas segundo seu nível de impacto para o desempenho dos negócios das empresas de real estate residencial em: baixo, médio e alto.

ii. A tomada de decisões por parte das empresas entrevistadas com relação aos seus interesses no mercado costarriquenho como possível objeto de ação.

iii. A justificativa da decisão tomada com base na avaliação dos elementos desse mercado (ambiente externo) e as características da companhia (ambiente interno).

\section{-Etapa Final}

Com os resultados obtidos nas etapas 1 e 2 concluiu-se sobre os elementos internos e externos relevantes nesta estratégia, e a atratividade do mercado da Costa Rica para as empresas entrevistadas.

\footnotetext{
${ }^{2}$ Desde 2010 a ENAHO substituiu a Enquete de Lares de Propósito Múltiplos (EHPM) pelas mudanças metodológicas realizadas. Os valores absolutos não podem ser comparados entre anos (INSTITUTO NACIONAL DE ESTATÍSTICA E CENSO, 2014b).
} 
Figura 1.1 - Estrutura da metodologia

\section{ETAPA 1}

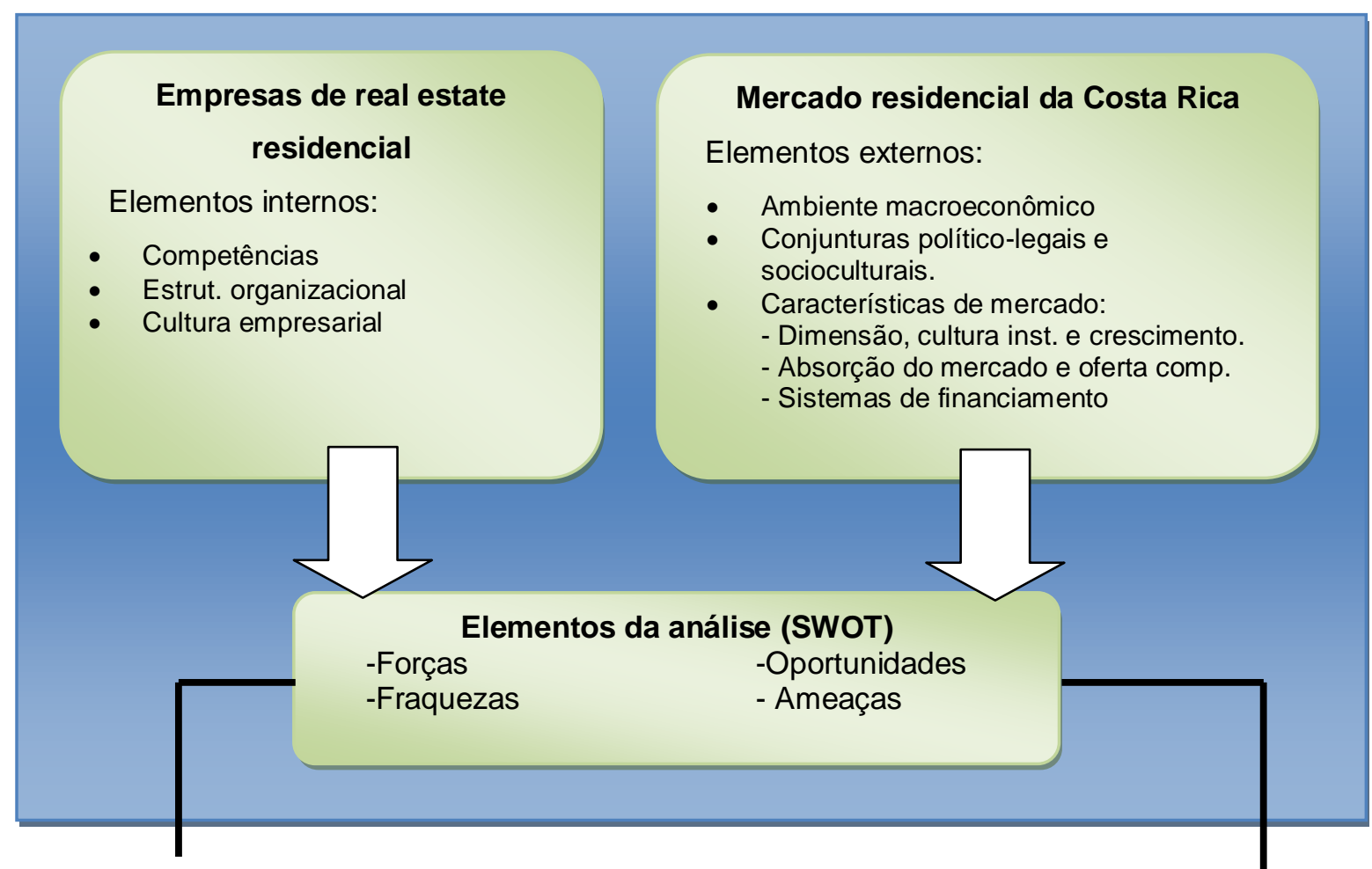

ETAPA 2

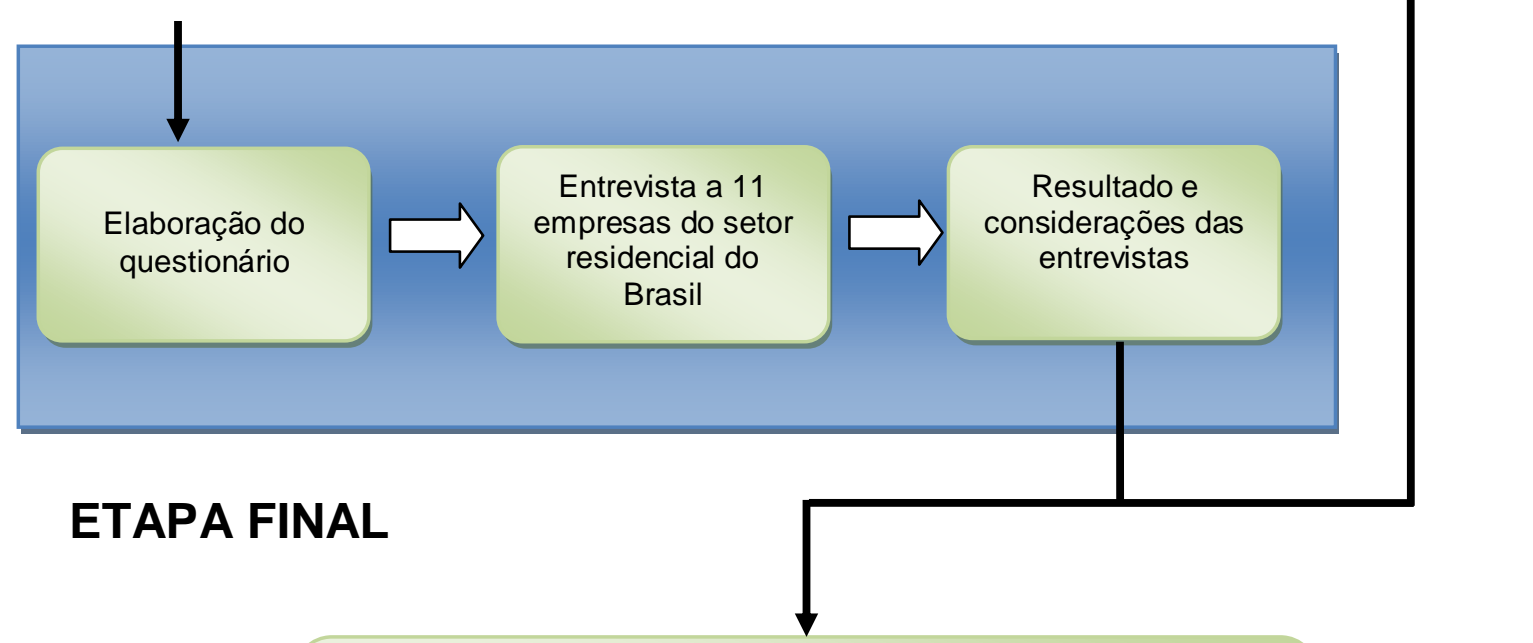

\section{Resultados}

- Elementos internos e externos relevantes na avaliação de estratégias de internacionalização

- Atratividade do mercado da Costa Rica para várias empresas brasileiras

Fonte: produção do próprio autor. 


\subsection{Estrutura do trabalho}

O texto da dissertação consta deste primeiro capítulo introdutório, que apresenta a justificativa e a motivação que deram origem ao desenvolvimento deste tema, assim como os objetivos e a metodologia para atingi-los.

O segundo capítulo contém o marco referencial do trabalho, neste se apresentam várias das teorias de internacionalização de empresa, enfatizando nos pressupostos do modelo de Uppsala como embasamento parcial ou integral para os possíveis processos de internacionalização das empresas brasileiras de real estate residencial.

O capítulo três apresenta a primeira parte da análise de base SWOT, na qual se distingue, teoricamente, do ambiente interno de empresas de real estate residencial, quais seriam suas forças e fraquezas envolvidas na estratégia de internacionalização.

A segunda parte da análise é desenvolvida no capítulo quatro, o qual distingue as ameaças e oportunidades para empresas de real estate residencial derivadas do estudo do mercado residencial costarriquenho e do ambiente econômico, político, legal e sociocultural do país.

No capítulo cinco é tratada a avaliação da atratividade do mercado residencial costarriquenho por empresas brasileiras de real estate. Este apresenta a estruturação do questionário que foi utilizado para esse fim; descreve as onze empresas entrevistadas, os resultados $e$ as considerações obtidas dessas entrevistas.

O capítulo seis apresenta as conclusões sobre o estudo da estratégia em questão, com base nos elementos internos e externos analisados, desenvolvendo essas conclusões com as considerações finais sobre o mercado costarriquenho. 


\section{INTERNACIONALIZAÇÃO DE EMPRESAS DE REAL ESTATE RESIDENCIAL}

Qualquer esforço ao se internacionalizar uma empresa visa expandir suas operações além de sua nação de origem, dessa forma, a internacionalização de uma empresa pode ser definida como o conjunto de operações que consiga estabelecer vínculos mais ou menos estáveis, entre esta com países fora de sua nação base, seja com transações, investimentos diretos ou projetos especiais (SÁNCHEZ, 2003; DAL-SOTO; ALVES; BULÉ, 2014).

Empresas com atividades internacionalizadas podem ser classificadas nos seguintes tipos, segundo Florentino e Gomes (2009):

- Empresa exportadora/importadora: realiza a comercialização de produtos.

- Empresa multinacional: pretende explorar as vantagens domésticas competitivas importantes, diversificando atividades em outros países. Esse tipo de empresa consegue nas filiais do exterior um modelo exato da empresa matriz.

- Empresa global: o objetivo é adquirir vantagem competitiva em termos de custos e receitas, através de operações centralizadas em escala global, sendo que suas atividades críticas devem concentrar-se em um ou poucos países.

- Empresa transnacional: combina adequadamente uma máxima eficiência econômica, uma máxima capacidade de responder a mercados locais e uma flexibilidade para transmitir as experiências que surgem em alguns países para toda a organização.

Desse modo, quando tratamos empresas de real estate residencial em processos de internacionalização, é pensando em um modelo de empresa multinacional com algum tipo de operação de investimento direto no estrangeiro, como a abertura de escritórios de serviços ou em parceria estratégica (e.g. joint ventures). 


\section{Por que internacionalizar?}

A literatura de estratégia empresarial e de internacionalização de empresas expõe vários motivos que levariam empresas de real estate residencial a expandir seu foco de atuação aos mercados internacionais.

Ansoff (1977) atesta que empresas em crescimento podem mover-se com um elo comum para o desenvolvimento de novos mercados. Assim, a busca de novas necessidades existentes para seus produtos atuais, em outros países, pode gerar uma internacionalização de suas atividades. Esse autor também afirma que essas mudanças estratégicas são consequência dos estímulos geradores provenientes de situações do ambiente externo, como a saturação do mercado atual, o declínio geral da procura, as pressões dos concorrentes ou a obsolescência dos produtos. Ademais, de pressões no interior da empresa, por obter uma maior rentabilidade de seus investimentos, ou diante uma condição de alta liquidez.

Da mesma forma, o interesse da empresa por novos mercados, em se expandir e crescer, pode ser produto da busca continuada de ganhos de qualidade para um melhor posicionamento relativo da empresa, com relação às demais de seu setor (ROCHA LIMA, 1994). Essas pressões da concorrência e da dinâmica dos mercados são tratadas com maior detalhamento na formulação de estratégias competitivas por Porter (1990).

Também, a estratégia de abranger mercados em outras latitudes pode ser produto de uma visão mais global e de um empreendedorismo empresarial (NUMMELA; SAARENKETO; PUUMALAINEN, 2004). Zapletalova (2014) argumenta que as empresas poderiam desejar participação em outros mercados como ferramenta para a competitividade da empresa; conseguindo por meio da extensão das atividades a níveis internacionais, uma cultura empresarial adaptável e flexível, ademais de desenvolver capacidades para aprender e aceitar as mudanças e ajustar-se às ocorrências de diversos ambientes (PRANGE; VERDIER, 2011).

Porém, para Kotler (2000) esta motivação viria, em muitos casos, pelo sentimento de ameaça, a partir do momento em que concorrentes dos mercados vizinhos 
produzissem melhores produtos ou serviços, e conseguissem invadir seus mercados de atuação. Ele também afirma que a presença em outros mercados pode ocorrer pela procura de mercados mais lucrativos ou de maior tamanho que o habitual, evitando, assim, a dependência de um único mercado com vários pontos de atuação.

Somam-se às possíveis razões para internacionalizar suas atividades: a migração para outras geografias dos clientes com um importante peso no portfólio de negócios da empresa (BARDHAN; KROLL, 2007), ou a procura de recursos mais confiáveis, e/ou de menor custo, que aumentem o retorno sobre investimento (URBAN; FLEURY, 2005).

Ao contrário dos estímulos geradores de Ansoff (1977), Rocha apud Dal-Soto; Alves e Bulé (2014) cita vários elementos do porquê das empresas brasileiras não se internacionalizarem, entre eles se mencionam as dificuldades originadas pelo isolamento geográfico e linguístico, pela formação cultural e pelo impacto do ambiente nas motivações empresariais.

\subsection{Teorias sobre internacionalização}

Numerosos pesquisadores têm tentado dar uma teoria consistente capaz de explicar os aspectos da internacionalização de todas as empresas, mas nenhum conseguiu explicar na plenitude, pois é um fenômeno complexo, de amplo escopo e de difícil integração teórica (DAL-SOTO; ALVES; BULÉ, 2014). Assim, essas tentativas de explicar os movimentos das empresas fora de seu país de origem têm se divido em duas grandes perspectivas: a econômica e a organizacional ou comportamental.

\subsubsection{Perspectiva econômica}

A internacionalização desde uma perspectiva econômica abrange aquelas teorias que descrevem esse processo com base nos custos e vantagens econômicas a fim de aumentar os retornos econômicos, é uma abordagem econômico-racional, pois 
considera a tomada de decisões e o comportamento das empresas como processos racionais, avaliando as condições sob as quais se pode determinar a localização ótima da produção (SÁNCHEZ, 2003). Sob essa perspectiva são elencados: a teoria da organização industrial, a teoria da internalização, o paradigma eclético de produção de Dunning e a abordagem macroeconômica, a serem explicados a seguir.

A abordagem da teoria da organização industrial ou teoria da vantagem monopolística, proposta por Kindleberger (1969) e Hymer (1976), explica que uma empresa poderia investir no estrangeiro quando esta possui algum tipo de vantagem competitiva exclusiva (monopolística), com a qual a empresa estrangeira poderia concorrer com as empresas locais, apesar de estas estarem estabelecidas, com conhecimento do mercado. Essa vantagem deve ser capaz de ser transferível, de grande magnitude e durável para resistir a erosão competitiva da concorrência. Tais vantagens originam-se de algum tipo de falha na estrutura do mercado, afirmam seus autores.

A teoria da internalização de Buckley e Casson (1976) explica que as organizações internacionais são um mecanismo alternativo do mercado para gerar atividades de valor entre países, com transações de produtos intermediários tangíveis e não tangíveis. A teoria postula que uma empresa seria motivada a fazer investimento estrangeiro quando: [i] existem vantagens de alocar atividades no exterior; [ii] é obtido um ganho maior por desenvolver essas atividades pela mesma empresa do que por vendê-las ou alugá-las a terceiros.

A teoria eclética de Dunning (1980) acopla várias das abordagens de ordem econômica, pois explica que o investimento direto de capital de uma empresa depende de quatro elementos, sendo eles: [i] vantagens específicas da empresa derivadas dos recursos tangíveis e intangíveis; [ii] essas vantagens devem ser mais rentáveis ao explorá-las por si mesma do que ao vender ou alugar estas a terceiros; [iii] a instalação da planta de produção no estrangeiro deve ser mais atrativa que no país base; [iv] o investimento direto no exterior da empresa deve ser parte da estratégia em longo prazo desta. 
Por último, a abordagem macroeconômica de Kojima (1982) explica que uma empresa internacionalizaria suas atividades em um país estrangeiro quando a atividade ou setor encontra-se em desvantagem comparativa em seu país base e tenha potencialmente vantagens competitivas no país estrangeiro. Ainda assim, essa abordagem tem sido criticada, principalmente por não ser uma explicação geral das atividades das multinacionais, explicando, acima de tudo, o caso particular desenvolvido por Kojima (SÁNCHEZ, 2003).

\subsubsection{Processo organizacional ou comportamental}

Desta perspectiva, considera-se a internacionalização como um processo que depende mais de variáveis subjetivas, pois tem seu centro nas atitudes, percepções e comportamento dos tomadores de decisões, os quais procuram a redução dos riscos na expansão (DAL-SOTO; ALVES; BULÉ, 2014). Isso é menos uma decisão racional, de passos planejados e deliberados, do que um fenômeno de natureza incremental, devido à acumulação de conhecimentos e aprendizagens nos mercados estrangeiros. Os principais processos de internacionalização dentro dessa categoria seriam: o modelo de Uppsala, o enfoque da inovação, o ciclo de vida do produto de Vernon e a teoria de redes, a serem explicados a seguir.

O modelo de Uppsala de Johanson e Wiedersheim-Paul (1975), e Johanson e Vahlne (1977), pode ser percebido como um processo de passos de natureza incremental, devido às incertezas e imperfeições das informações do novo mercado, o qual envolve maior quantidade de recursos envolvidos na operação, segundo a acumulação de conhecimentos do novo mercado. Esse movimento fora do país base se origina como consequência de seu crescimento e da saturação da demanda doméstica. $O$ detalhe desse modelo será explicado posteriormente.

O enfoque da inovação explica um paralelismo entre a internacionalização e a inovação, pois ambas são decisões criativas e deliberadas, desenvolvidas dentro dos limites do mercado e segundo as capacidades da empresa, em condições de incerteza. Considera-se uma visão mais proativa nesse processo, pois é necessário 
constante esforço de aprendizagem, sem esquecer as condições do meio, as capacidades das empresas e as experiências passadas (SÁNCHEZ, 2003).

O enfoque do ciclo de vida do produto de Vernon (1966) utiliza o ciclo de vida do produto para explicar o comportamento individual de cada empresa, induzindo aspectos como inovação do produto, efeitos das economias de escala e incerteza dos negócios internacionais. Assim, explica como no começo a produção será realizada só no mercado local, até um próximo estágio, no qual o produto começa a ser exportado, aproveitando principalmente as vantagens produtivas e de inovação, em direção aos mercados com padrões de demanda similares aos do país origem. Por último, dependendo das condições do novo mercado, pode aumentar o atrativo de trasladar as atividades de valor fora do país base a este.

A teoria de redes (networks) baseia-se nos processos de internacionalização com um desenvolvimento lógico das redes interorganizacionais e sociais da empresa (SÁNCHEZ, 2003). Nessa teoria, são exploradas as oportunidades empresariais para os indivíduos, atores das empresas, com vínculos exclusivos e não redundantes, com grupos distanciados; que habituem viajar ou trabalhar no exterior, e com experiências imigratórias.

Para pequenas e medianas empresas, a criação de redes pode ajudar a não depender de seus recursos e a não haver limitações para o crescimento, aumentado as oportunidades de novos negócios, como a internacionalização, com a procura de sócios estrangeiros, parcerias com clientes e fornecedores, como ponte para mercados externos.

\section{Modelo de Uppsala}

A Universidade de Uppsala, na década de 70, interessou-se pelos processos de internacionalização, baseados no modelo de desenvolvimento das firmas suecas manufatureiras. O modelo explica como, de acordo com a empresa, vai se adquirindo maior conhecimento do novo mercado, assim seria seu comprometimento crescente com este, usando em cada estágio do processo um modo de entrada distinto, que envolve maior quantidade de recursos na operação (Ver Figura 2.1). 
Esse processo incremental é percebido em duas dimensões: a primeira, evoluindo de mercados similares aos mercados locais para mercados "psiquicamente" mais distantes; e a segunda, no grau de envolvimento da empresa, iniciando um leve nível para testar o mercado, até um comprometimento total. A velocidade e progresso das duas movimentações dependerão da aprendizagem e conhecimento adquiridos no processo (HILAL; HEMAIS, 2003).

Figura 2.1 - Estágios de envolvimento internacional

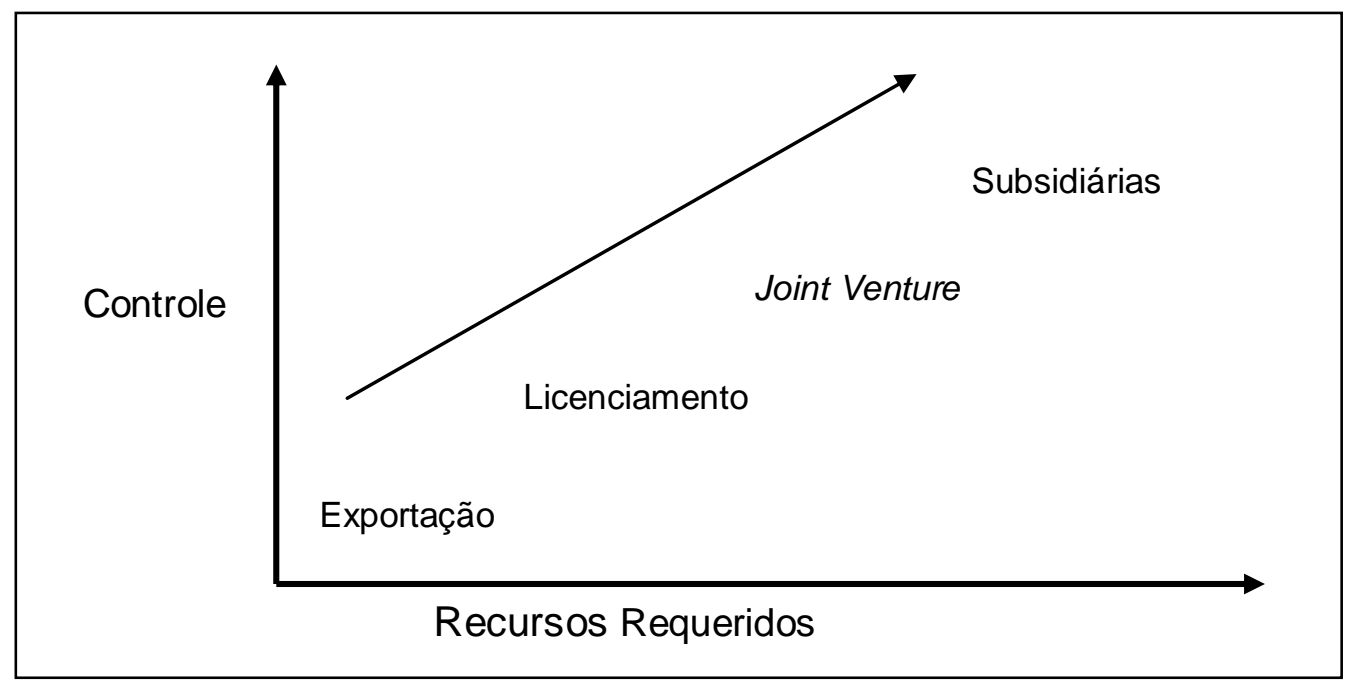

Fonte: Osland, Taylor e Zou (2001) modificado pelo autor

O modelo introduz o conceito de "distância psíquica", que se define como o conjunto de elementos que dificultariam a recepção de informação da empresa do mercado, relacionado às diferenças culturais, de linguagem, políticas, religiosas, etc. Este elemento toma importância nas decisões da escolha do mercado alvo, compondo os mercados com menor distância psíquica os primeiros objetivos na estratégia.

$\mathrm{Na}$ evolução desse modelo, a Escola Nórdica de Negócios Internacionais propõe que as empresas não precisam desse crescimento gradual estritamente, podendo pular estágios ou usar um determinado modelo. Também Sánchez (2003) argumenta que quando as empresas desenvolvem alguma experiência internacional, esta poderia usar outros critérios ao tomar decisões, como o tamanho de mercado e oportunidades, e condições mercadológicas econômicas globais. 


\subsubsection{Empresas “Born Global”}

"Born Global" ou enfoque global é utilizado para empresas de existência relativamente nova, criadas para se desenvolverem em ambientes internacionais, que desde seus surgimentos têm um foco global ou conseguem internacionalizar-se rapidamente (ZAPLETALOVA, 2014). Empresas desse tipo são de setores concretos, como alta tecnologia e atividades artesanais. A criação dessas empresas deve-se principalmente: às novas condições do mercado mundial; ao desenvolvimento tecnológico nas áreas de produção, transporte e comunicação, e ao empreendedorismo das pessoas que tomam decisões nas empresas (SÁNCHEZ, 2003).

\subsection{Empresas de real estate residencial em processos de internacionalização}

Como foi comentado na contribuição acadêmica deste trabalho, a literatura referente à internacionalização das empresas de real estate residencial é escassa, previamente, nenhum pesquisador tem se referido concretamente às teorias que possam explicar a internacionalização das empresas desse setor. Ainda assim, esse tipo de empresa consta de características comuns com empresas de outros setores. Portanto, pode ser sugerida alguma das abordagens antes citadas, para explicar uma possível internacionalização dessas empresas.

Assim, a internacionalização das empresas de real estate residencial dificilmente pode ser explicada unicamente desde uma perspectiva econômica, pois muitas dessas abordagens se baseiam em uma vantagem competitiva exclusiva, capaz de fazer frente à concorrência local. Entretanto, no caso do setor residencial, dificilmente poderia existir vantagens de tal dimensão. Por exemplo, vantagens na área tecnológica constam de pouco valor, pois o grau de tecnologia envolvido nesse setor é leve e filtra-se facilmente. Vantagens em produtos específicos perdem todo o valor, pois os produtos residenciais devem responder aos anseios e desejos dos clientes, e aos padrões culturais da região, assim o produto teria que mudar ao ser proposto em um país diferente. 
Por outro lado, processos comportamentais poderiam aproximar-se mais a explicar a possível internacionalização de empresas de real estate residencial. Por exemplo, a teoria de redes explicaria como algumas firmas norte-americanas de real estate têm se inserido nos mercados da China e da Índia, em projetos residências e comerciais, acompanhando multinacionais também norte-americanas, pois pela qualidade destas em seus produtos, são procuradas por expatriados e clientes internacionais (BARDHAN; KROLL, 2007).

Para nosso caso, podem ser utilizados os pressupostos do modelo de Uppsala como embasamento parcial ou integral para os possíveis processos de internacionalização das empresas brasileiras de real estate residencial, considerando que:

- esse modelo pode ser usado para empresas de médio e pequeno porte ${ }^{3}$, como as empresas estudadas neste trabalho;

- o modelo possui maior poder explanatório para firmas inexperientes em processos de internacionalização e é conveniente para a aplicação no contexto das empresas brasileiras (BARRETTO, 2002 apud DAL-SOTO; ALVES; BULÉ, 2014);

- as empresas do setor residencial brasileiro, devido ao aumento no volume de obras realizadas nos últimos anos, tiveram um crescimento em seus recursos tangíveis e intangíveis (SOUZA, 2011), adquirindo novas habilidades e competências capazes de atingir novos âmbitos de atuação dentro de sua estratégia empresarial, como o internacional.

Deve-se alertar que um dos pressupostos do Modelo considera o movimento das empresas para mercados internacionais como consequência de seu crescimento e da saturação da demanda doméstica. A primeira condição foi justificada no parágrafo anterior, mas a segunda condição não está presente no mercado brasileiro para empresas desse setor, pois, como comenta Dal-Soto; Alves e Bulé (2014, p. 186): "[...] inúmeras empresas brasileiras, de diferentes portes e setores, têm encontrado no mercado doméstico um potencial muito significativo de consumo, o que retarda ou descarta a internacionalização dessas empresas".

\footnotetext{
${ }^{3}$ Tamanho relativo às dimensões de empresas de ordem mundial.
} 


\subsubsection{Expansão geográfica das empresas brasileiras de real estate residencial sob o Modelo Uppsala}

Principalmente entre os anos 2005 e 2006, várias empresas brasileiras de real estate residencial de grande porte abriram-se ao mercado de capitais, com o que ficaram financeiramente mais robustas e procuraram assim, novas oportunidades de negócios para cobrir os objetivos de seus acionistas, de modo que optaram por canais de crescimento, como a diversificação geográfica (de mercados) e de segmentos de renda (produtos) nos anos subsequentes (2006-2010) (SOUZA, 2011).

Essa estratégia de crescimento e expansão poderia ilustrar um processo similar a uma internacionalização ${ }^{4}$ em seus primeiros estágios, sob os pressupostos do enfoque do Modelo Uppsala, no qual são recolhidos certos conhecimentos e aprendizagens sobre os processos de expansão, que seriam úteis para atingir mercados com distancias psíquicas maiores, como por exemplo, Costa Rica.

Essa expansão contou com várias características como:

1. O cenário foi modificado abruptamente, os efeitos da ação das grandes incorporadoras foram sendo percebidos primeiramente nos mercados próximos das economias mais fortes do Brasil, Rio de Janeiro e São Paulo, onde estas empresas estavam estabelecidas, até regiões nunca exploradas (ALBUQUERQUE; ALENCAR, 2011).

2. Várias dessas empresas também se expandiram com novos produtos para faixas de renda sobre os quais não tinham experiência (ROCHA LIMA, 2012).

3. O modelo de negócios predominante para ingressar nos novos mercados foi o da parceria, justificado por Alencar (2012), por ser um modelo de ágil implementação, e não requer um redesenho organizacional, nem tempo para que opere com eficiência, como outros tipos.

Assim, o ponto 1 mostra uma rápida velocidade na expansão, contrário ao processo incremental, que aumenta sua participação de recursos envolvidos no

\footnotetext{
${ }^{4}$ Até mesmo pelas dimensões do território brasileiro.
} 
novo mercado, segundo o grau de conhecimento adquirido deste, o qual geralmente emana lentamente. Embora a expansão tenha começado próxima aos mercados habituais dessas empresas, sua explosão para outros mercados desconhecidos foi quase imediata.

O processo incremental deve considerar o conhecimento e aprendizagem do novo mercado, e também, incluir a evolução do portfólio de recursos tangíveis e intangíveis da empresa, sendo o capital próprio o único recurso considerado nessa expansão. Portanto, não foram avaliadas as competências essenciais da empresa, segundo a estratégia considerada, apresentando carência das competências inerentes às empresas de real estate, por várias companhias envolvidas (ALENCAR, 2012).

No ponto 2 foram ignoradas as incertezas e imperfeições das informações do novo mercado, pois a diversificação aumentou o risco das atividades e influiu no desempenho das empresas, mostrando prejuízos nos resultados dos balanços de 2011 de muitas incorporadoras (ROCHA LIMA, 2012).

O ponto 3 carece de estágios de envolvimento, conforme o incremento gradual de conhecimentos do mercado, pois foi a parceria o modelo predominante por sua praticidade, sem utilizar modos de entradas de menos envolvimento de recursos para testar o novo mercado e os parceiros econômicos.

Somado a isso, o elemento da distância psíquica foi subestimado no momento de desenvolver estas parcerias. Fé (2012) aponta que os maiores fracassos apresentaram-se nas empresas que não foram capazes de se adaptar nas alianças estratégicas com os parceiros locais, mostrando diferenças de cultura empresarias e de sistemas de controle, com auditoria e legalidade pouco flexíveis para o tipo de aliança, sem aproveitar as vantagens do conhecimento local aportado pela empresa regional. 


\subsubsection{Formulação de estratégias de expansão internacional com uma abordagem SWOT}

Dessa análise prévia são resgatados os seguintes pontos, como falhas ou elementos fracos que deveriam ser consolidados em futuras expansões geográficas, como em uma internacionalização:

- desconhecimento dos elementos do novo mercado alcançado. Como argumenta Zapletalova (2014), tomar vantagem das oportunidades dos mercados internacionais requer preparação e conhecimento de suas particularidades e singularidades, até mesmo porque o conhecimento do mercado é a chave para aumentar os recursos envolvidos na operação, segundo o Modelo Uppsala.

- Desconhecimento do próprio portfólio de recursos intangíveis: competências essenciais, cultura empresarial e fraquezas.

Essas informações necessárias para a tomada de decisões sobre a estratégia de internacionalização podem ser geradas com algum tipo de ferramenta analítica, pois em síntese, foi o desconhecimento do novo mercado e de suas próprias competências e fraquezas o motivo que levou a muitas empresas a falhar na expansão geográfica.

Assim, para o presente trabalho, é proposta a utilização do SWOT (Strengths, Weaknesses, Opportunities and Threats) ou FOFA, em português, (Forças, Oportunidades, Fraquezas e Ameaças). Essa ferramenta examina os atributos da empresa como: recursos, pessoal, facilidades, locação, produtos, serviços, habilidades e competências; e do mercado, a saber: as forças macroambientais (economia, demografia, tecnologia, política-legislação e sociocultural) e os agentes microambientais (clientes, concorrentes, distribuidores e fornecedores), na procura dos elementos úteis e prejudiciais para conseguir os objetivos planejados pela empresa na estratégia (Ver Figura 2.2).

Dessa forma, essa análise permite a interação entre ambos os ambientes, externo e interno, apropriada para mostrar os atributos de empresas de real estate e do 
mercado costarriquenho, base para a tomada de decisões e avaliação da estratégia em questão.

Figura 2.2 - Estrutura da análise SWOT

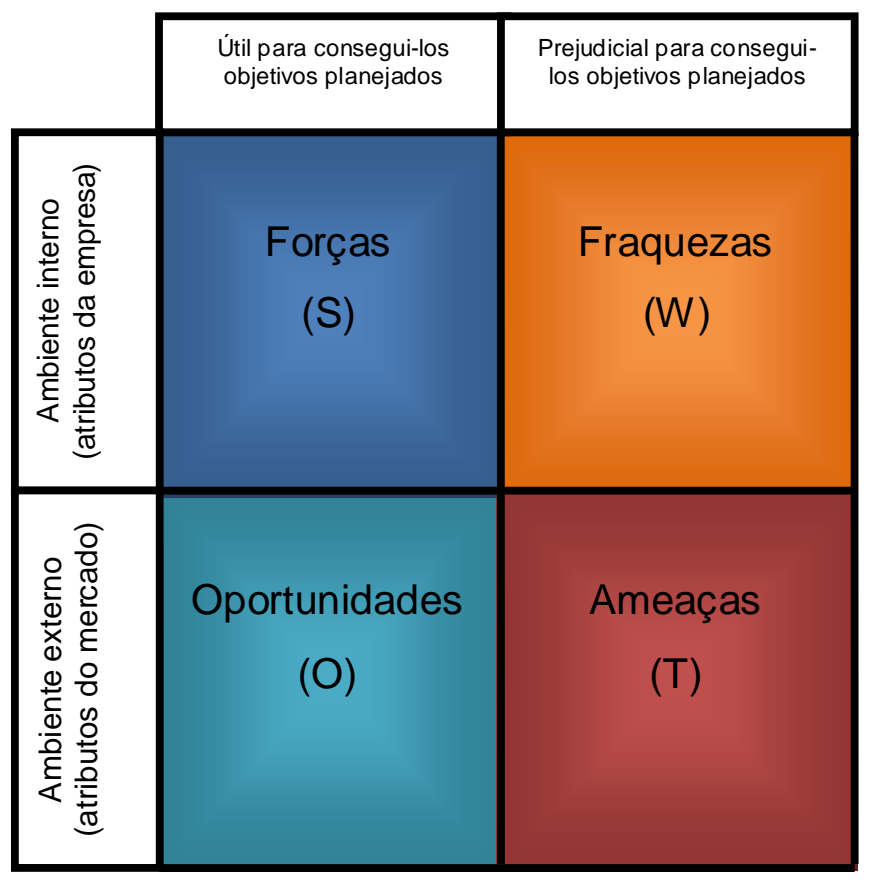

Fonte: produção do próprio autor

\section{a. Antecedentes do SWOT}

Esta análise tem origem na década de 1960 com Learned et al. (1965) e é desenvolvida, por vários autores, a partir de então: Weihrich (1982), O'Shaughnessy (1988) e Greenley (1986), Kotler (1991), Wilson et al. (1992), Aaker (1992), Johnson e Scholes (1993), McDonald (1992), Fifield (1992), Palmer e Hartley (1996) (PICKTON; WRIGHT, 1998; DYSON, 2004; LU, 2010).

Em processos decisivos, autores clássicos de estratégia empresarial, como Ansoff (1977), inserem este tipo de avaliação ambiental entre as primeiras atividades no processo de formulação estratégica, depois que a empresa formulou os objetivos e escolheu as metas (ver Figura 2.3). Também Kotler e Keller (2006) situam essa análise de ambientes externos e internos, nas primeiras atividades, para o processo de planejamento estratégico de unidades de negócios. 
Figura 2.3 - Decisões no Processo de Formulação de Estratégias

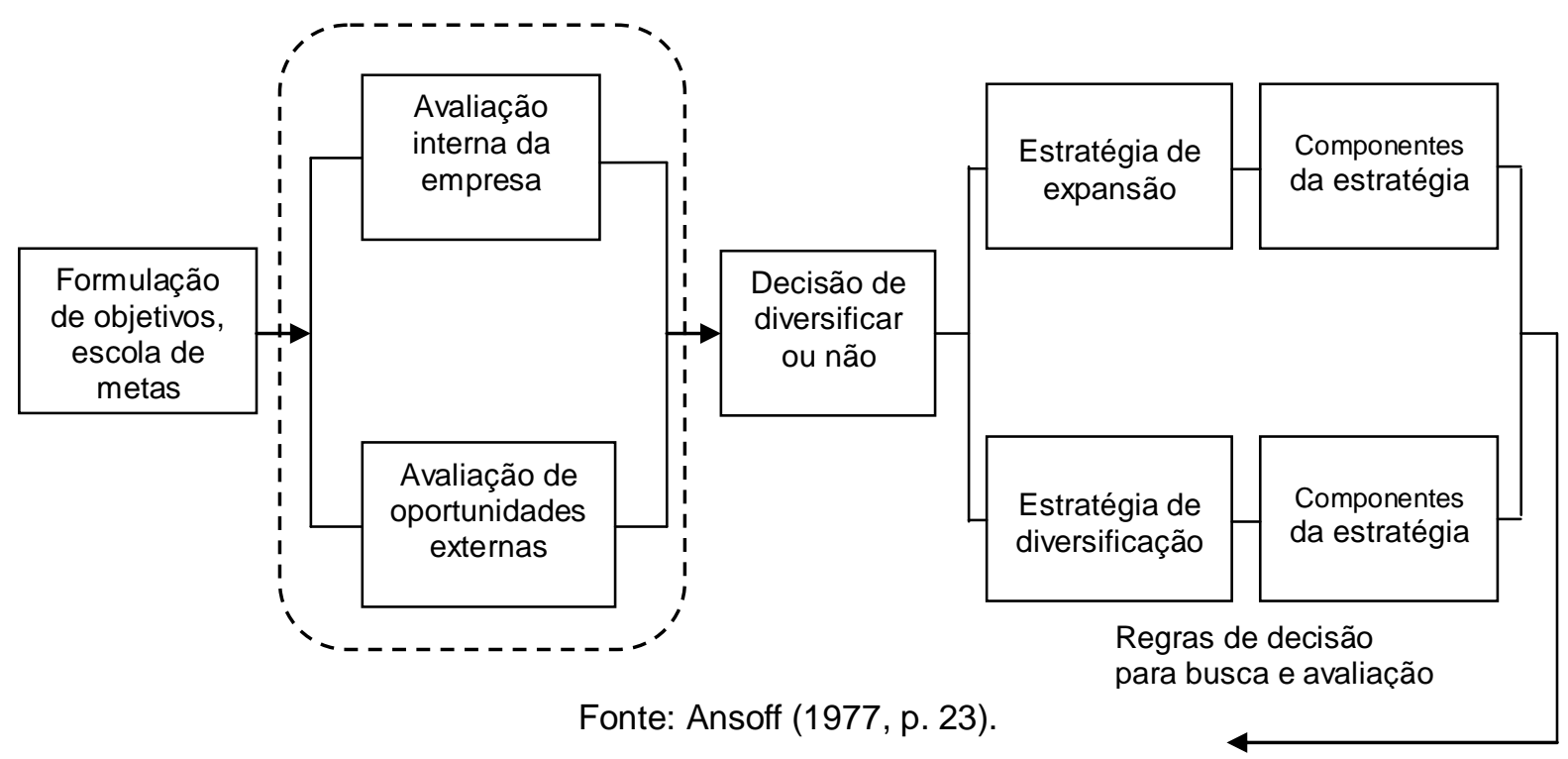

Ainda que seja uma análise desenvolvida há algum tempo, não se trata de uma ferramenta desatualizada, pois sua flexibilidade permite que a análise seja potencializada e enriquecida por novas abordagens, por exemplo, com a teoria "Baseada nos Recursos da Firma" (resource based view of the firm) de Penrose (1995); as competências essenciais empresariais de Barney (1991), e Prahalad e Hamel (1998), e a simulação de cenários (DYSON, 2004; LU, 2010).

A análise SWOT é prática, simples e pode ser aplicada facilmente em companhias, corporações, projetos e instituições (DYSON, 2004). Na atualidade, também é ferramenta útil para monitorar o mercado e a posição competitiva dos negócios, chamada por Pickton e Wright (1998) de "Environmental Scanning" (Varredura Ambiental).

\section{b. Limitações, vieses e evolução da ferramenta}

De maneira contrastante, a simplicidade que caracteriza sua aplicação, encontrada na lista das vantagens da ferramenta é seu ponto fraco quando se refere à criação de planos de atuação para as empresas. 
Pickton e Wright (1998), em suas pesquisas, encontraram que autores, tais como Aaker (1992), O'Shaughnessy (1988) e Greenley (1986) recomendam não usar essa ferramenta no início dos processos de planejamento. A Tabela 2.1 apresenta um resumo dos vieses encontrados por estes autores.

Tabela 2.1 - Vieses do SWOT

\begin{tabular}{|c|c|c|}
\hline $\begin{array}{l}\text { Inadequada definição dos } \\
\text { fatores }\end{array}$ & $\begin{array}{l}\text { Carência de priorização de } \\
\text { fatores }\end{array}$ & $\begin{array}{c}\text { Sobressubjetividade na } \\
\text { geração de fatores: } \\
\text { compilador de viés }\end{array}$ \\
\hline $\begin{array}{l}\text { Fatores que aparecem em mais } \\
\text { de uma categoria }\end{array}$ & Fatores que têm muitas ênfases & $\begin{array}{l}\text { Fatores que ficaram fora, } \\
\text { carência de relevância }\end{array}$ \\
\hline $\begin{array}{l}\text { Fatores que não aparecem em } \\
\text { nenhuma categoria }\end{array}$ & Fatores que têm & $\begin{array}{l}\text { Aleatoriedade na geração de } \\
\text { fatores }\end{array}$ \\
\hline $\begin{array}{l}\text { Fatores que são descritos } \\
\text { amplamente ou escassamente }\end{array}$ & $\begin{array}{l}\text { Fatores que são emparelhados } \\
\text { em importância }\end{array}$ & $\begin{array}{l}\text { Discordância sobre os fatores e } \\
\text { sua categoria }\end{array}$ \\
\hline $\begin{array}{l}\text { Carência de informação para } \\
\text { especificar fatores pontuais }\end{array}$ & & $\begin{array}{l}\text { Fatores apresentam opiniões, } \\
\text { não fatos }\end{array}$ \\
\hline
\end{tabular}

Fonte: Traduzido de Pickton e Wright (1998, p. 105).

Outros autores como Lu (2010) criticam esse método, referindo-se em relação a seus resultados como uma "simples lista", sem informação suficiente para criar uma opção estratégica de atuação. Ademais, Liu e Chen (2012) apontam a dificuldade na tomada de decisões pela falta de critérios numéricos, pois sua aplicação permite resultados meramente qualitativos, mas não quantitativos.

Soma-se a estes problemas intrínsecos da ferramenta, a execução da análise, que pode diminuir a qualidade da informação, quando é utilizado como um processo mecânico e não na dinâmica da gestão empresarial nos processos de desenvolvimento dos negócios (PICKTON; WRIGHT, 1998).

Com base nestas críticas, as reformas da análise SWOT têm sido focadas em seu ponto chave, a identificação dos fatores que afetam o desenvolvimento e o crescimento do negócio da empresa. Assim, essa ferramenta é incrementada com processos adicionais como: a valoração dos fatores, sistemas de notas para reconhecer seu impacto e prioridade, e uso da probabilidade de ocorrência, com exceção da subjetividade dos resultados. 
Para a tomada de decisões nos primeiros estágios estratégicos, como proposto neste trabalho, um enfoque SWOT fornece informação clara e prática para este trabalho. Além disso, o retorno da análise é incrementado com entrevistas a várias empresas brasileiras de real estate residencial, para identificar os fatores mais relevantes nessa estratégia para essas empresas e com um sistema de notas para as ameaças e oportunidades do mercado residencial estrangeiro. 


\section{ANÁLISE DO AMBIENTE INTERNO DE EMPRESAS DE REAL ESTATE RESIDENCIAL: FORÇAS E FRAQUEZAS}

Para analisar uma possível expansão de empresas brasileiras de real estate residencial no mercado costarriquenho, o problema foi dividido a partir de uma abordagem SWOT em duas partes: a primeira parte consiste na identificação das forças e das fraquezas do ambiente interno de empresas de real estate residencial em estratégias de expansão internacional, apresentadas neste capítulo; a segunda parte analisa as oportunidades e ameaças do mercado residencial costarriquenho e outras variáveis que incidem nesse mercado, apresentadas no próximo capítulo.

Cada fator estratégico discriminado na análise será sintetizado e apresentado dentro de uma caixa de texto.

\subsection{Forças (Strengths)}

Apesar de, no ambiente interno, a ferramenta SWOT examinar recursos, pessoal, facilidades, locação, produtos, serviços, habilidades e competências; pela complexidade na qual podem ser agrupados os recursos tangíveis desse grupo de empresas, os quais careceram, em muitos casos, de elementos em comum, a análise dos atributos da empresa para obter as forças corresponderá unicamente às competências essenciais ${ }^{5}$ e habilidades necessárias para esse processo, trazendo para dentro da companhia o foco da análise para processos de crescimento e expansão (BARNEY, 1991; JAVIDAN, 1998; PRAHALAD; HAMEL, 1998).

Para empresas com limitações de recursos para processos de internacionalização, como as estudadas neste trabalho, Borini, Floriani e Fleury (2012) mostram que existe a necessidade de desenvolver competências para a organização do processo de internacionalização, assim como competências relacionadas às diferentes áreas funcionais da empresa, pois dependem destas para se manterem competitivas nos

\footnotetext{
${ }^{5}$ Prahalad e Hamel (1998, p. 298) definem as competências essenciais como: "[...] o aprendizado coletivo na organização, especialmente como coordenar as diversas habilidades de produção e integrar as múltiplas correntes de tecnologias".
} 
ambientes internacionais. Portanto, o trabalho levanta teoricamente as competências necessárias para internacionalizar as atividades da empresa, para depois, examinar as competências próprias das companhias de real estate.

Assim, para analisar as competências necessárias para processos de internacionalização, utilizou-se a literatura sobre internacionalização das empresas (HILAL; HEMAIS, 2003; URBAN; FLEURY, 2005; BARDHAN; KROLL, 2007; VARGAS, 2008; FLORENTINO; GOMES, 2009), e para as competências próprias das companhias de real estate, valeu-se da informação desta área de pesquisa, com o reconhecimento dos elementos estratégicos e das competências sugeridas pela literatura como aspectos intrínsecos a estas empresas. Baseou-se no estudo de Linjie (2011), por ter uma abordagem similar à análise SWOT na integração dos elementos internos e externos.

Além disso, o tema foi complementado com o trabalho de Gibler et al. (2002), e Manning e Epley (2006), com o incremento das áreas de conhecimento necessárias para as empresas de real estate, e contextualizado no cenário brasileiro, com os trabalhos de Monetti (2009), Souza (2011), o Comitê de Mercado EPUSP (2012) e Fé (2012).

\subsubsection{Competências essenciais para estratégias de internacionalização}

A literatura sobre internacionalização de empresas não distingue concretamente uma lista de competências essenciais necessárias para que uma empresa internacionalize suas atividades. Por este motivo, autores como Hilal e Hemais (2003); Urban e Fleury (2005); Vargas (2008), e Florentino e Gomes (2009) apoiamse em estudos de caso, para mostrar as competências desenvolvidas durante os processos de internacionalização.

Nos casos estudados por estes autores, observa-se que as empresas desenvolvem as competências necessárias conforme o tipo de negócio, o modo de entrada no novo mercado e as características do mercado, não mostrando um padrão único entre elas. 
Urban e Fleury (2005) concluem que as competências chaves da Embraer S.A., conglomerado brasileiro fabricante de aviões, estavam na área do design e gestão do projeto, assim como a capacidade de compreender as necessidades dos usuários em seu nicho de comercialização, absorção rápida de capacidades tecnológicas, competitividade de custo, desenvolvimento de famílias de novos produtos e serviços de apoio ao cliente. Mas como os mesmos autores enfatizam, estas competências não estão diretamente relacionadas à internacionalização da empresa e são, acima de tudo, habilidades próprias da empresa que garantem o seu sucesso no mercado local e internacional.

\section{Força}

S.1. A empresa é capaz de criar novas competências dependendo das condições do mercado e da estratégia implementada.

Por outro lado, a alta qualidade apresentada nos atributos dos projetos e o fornecimento de uma ampla gama de serviços em seus mercados de atuação, seriam os principais elementos em comum da mostra de 326 companhias norteamericanas $^{6}$ de real estate que estão conseguindo entrar em mercados internacionais segundo Bardhan e Kroll (2007). Portanto um indicador para considerar uma possível internacionalização das atividades de uma empresa deve ser a qualidade e atributos de seus produtos.

\section{Força}

S.2. A empresa desenvolve competências que são refletidas em seus produtos no mercado local, mostrando uma atuação diferenciada à da concorrência.

Outra competência reconhecida por autores como Urban e Fleury (2005); Bardhan e Kroll (2007); Vargas (2008), e Paim (2009) como indispensável para atuar em

\footnotetext{
${ }^{6}$ Para a análise feita no estudo de Bardhan e Kroll (2007) basearam-se em dados da OneSource na determinação da extensão em que as grandes empresas (500 colaboradores ou mais) do setor imobiliário norte-americano estão acessando mercados globais. O estudo é incrementado com uma pesquisa às empresas listadas à Fisher Center for Real Estate and Urban Economics Policy Advisory Board.
} 
ambientes internacionais é o relacionamento com parceiros externos, principalmente com o objetivo de ter acesso ao conhecimento "local" do mercado, fator fundamental na indústria do real estate.

O valor desta habilidade é reconhecido por empresas brasileiras como a Camargo Corrêa Desenvolvimento Imobiliário (CCDI), que para entrar em novos estados no interior de São Paulo entre os anos de 2005 e 2010, optou pela realização de parcerias com empresas que forneceriam o conhecimento local (SOUZA, 2011). Também o caso da Gafisa que afirma que "desde 2004, a empresa firmou novas parcerias, o que facilita o acesso da companhia a mercados estratégicos fora do Rio de Janeiro e São Paulo" (GAFISA, 2006 apud SOUZA, 2011).

Esta habilidade terá sua utilidade na formação de alianças estratégicas horizontais com empresas de sua mesma atuação, ou alianças verticais, como empresas prestadoras de serviços (marketing, legal), fornecedores de material e equipo, entre outras. Por exemplo, a empresa brasileira CR2 Empreendimentos Imobiliários S.A, constituída no ano de 2006, ao contrário de muitas de seus concorrentes, não possui construtora própria; assim, terceiriza todas as atividades de construção e corretagem (SOUZA, 2011).

Vargas (2008) desenvolve mais amplamente a necessidade desta competência em ambientes internacionais turbulentos. Construtoras do nível da Norberto Odebrecht ${ }^{7}$ devem seu sucesso, em parte, à formação de relações estreitas como grupos de importante participação nos projetos, tais como: sindicalistas, comunidade, governo (prefeituras) e, até nos casos mais extremos, com grupos guerrilheiros e outros grupos violentos.

\section{Força}

S.3. A empresa desenvolve boas relações com parceiros externos.

\footnotetext{
${ }^{7}$ Vargas (2008) em seu caso de estudo não menciona que este foi a empresa construtora Norberto Odebrecht, mas o perfil da empresa, data de fundação, posicionamento a nível mundial e suas participações, levaram ao autor a concluir o nome desta, colocá-lo no texto para dar maior força aos argumentos da importância das relações com parceiros externos, devido logros obtidos por esta empresa.
} 
Por último, Bardhan e Kroll (2007) levantam uma questão referente às firmas norteamericanas de real estate antes mencionadas concluindo que, devido à qualidade destas em seus produtos, expatriados e clientes internacionais se motivam a procurar estas empresas no estrangeiro, gerando oportunidades de internacionalização devido aos processos de globalização. Assim, multinacionais norte-americanas (não especificadas no estudo) têm incursionado nos mercados da China e da Índia acompanhadas destas empresas de real estate para o desenvolvimento de projetos residenciais e comercias.

\section{Força}

S.4. A empresa tem parceiros econômicos interessados em diversificar seus investimentos em mercados internacionais.

\subsubsection{Competências essenciais das empresas de real estate}

Linjie (2011) define o núcleo de competências das empresas de real estate como:
"a coordenação de diversos níveis de produção da empresa e da acumulação, integração e uso efetivo dos recursos internos e externos para identificar e desenvolver o mercado de real estate, melhorando a qualidade do uso do solo, qualidade habitacional, valor do projeto e eficiente gestão permitindo obter a competitividade sustentável." (LINJIE, 2011, p.2)

Esta abordagem está baseada em uma análise de três dimensões: rentabilidade do produto e mercado, funcionamento da empresa com recurso interno e externo, e desenvolvimento futuro da empresa. Assim são criados os três indicadores ou competências principais das empresas de real estate:

- habilidades de desempenho (performance),

- habilidades básicas, e

- capacidades potenciais 


\section{a. Habilidade de desempenho}

A habilidade de desempenho (performance) está relacionada com a compreensão do ciclo da indústria, projetando um planejamento adequado, desenho (design) e marketing do produto, cumprindo a qualidade desejada pelo mercado.

Uma empresa que tenha pleno domínio destas habilidades estará caracterizada por ficar sempre acima do padrão da concorrência, com projetos bem sucedidos e de uma marca empresarial diferenciada.

\section{Força}

S.5. A empresa entende os ciclos e processos do mercado local, refletindo em um planejamento adequado, desenho e marketing do produto, cumprindo as expectativas dos clientes.

\section{b. Habilidades básicas}

O segundo grupo de habilidades principais corresponde às habilidades básicas das empresas de real estate, que se dividem em quatro subgrupos. O primeiro subgrupo é das providências de prevenção contra ameaças externas. Entre estas encontramos o desenvolvimento de estratégias adaptáveis e a posse de uma estrutura organizacional capaz de responder ao meio ambiente.

\section{Força}

S.6. A empresa pode responder adequadamente às ameaças externas com sua estrutura organizacional e suas estratégias empresariais adaptáveis.

O segundo subgrupo corresponde a proteger seus empreendimentos contra ameaças externas por meio da gestão e análise do risco de seus projetos, conhecimento das regulações governamentais e aspectos legais. 
Monetti (2009) aponta essa força como elemento necessário para as incorporadoras no cenário de real estate brasileiro depois da Crise Mundial de 2008, e a divide em dois ambientes:

i. Em um ambiente tático, para avaliar a qualidade do investimento em cada empreendimento. Ela destaca como pontos necessários: um decisor capaz de avaliar os riscos incorridos na tomada de decisões de cada empreendimento e a qualidade nas informações em que este se apoia.

ii. Em um ambiente operacional, para a possível mitigação dos desvios de comportamento ao longo da implantação dos empreendimentos. São destacados como pontos necessários a estruturação e implementação de sistema de controle.

\section{Força}

S.7. A empresa pode reconhecer o risco de seus investimentos, antes e durante cada ciclo de investimento/retorno.

O terceiro subgrupo corresponde a habilidades próprias da corporação, como gestão contábil, finanças corporativas e gestão de taxas e impostos.

\section{Força}

S.8. A empresa tem boa gestão dos recursos financeiros nas áreas de finanças corporativas, contábil e tributos.

O quarto e último subgrupo corresponde às competências gerenciais: project e construction management. Estas competências gerenciais no contexto das empresas do setor residencial são explicadas por Comitê de Mercado EPUSP, o qual discute sobre as competências-chave para as incorporadoras brasileiras no cenário atual do mercado de real estate. Estas seriam:

- O project management: "orientado ao atendimento das expectativas do desempenho da implantação do empreendimento", representa um conjunto de processos gerenciais com ênfase na implantação e exploração de um dado empreendimento, orientados para a singularidade de cada projeto 
(project oriented). Ele considera aspectos tais como a gestão de escopo, prazo, recursos, custos e riscos relacionados a todo o ciclo de vida do negócio e exclui os processos relacionados à execução do produto imobiliário.

- O construction management (gestão da produção) consiste em "processos gerenciais e práticas de trabalho que admitem sua repetitividade nas obras associadas aos produtos imobiliários". Estes, orientados à produção e execução do produto imobiliário, inclui a supervisão e execução das atividades e tarefas da cadeia de produção, além daquelas associadas à logística e fornecimento de materiais, equipamentos e mão de obra (COMITÊ DE MERCADO EPUSP, 2012, p. 3)

\section{Força}

S.9. A empresa conta com competências nas áreas de project e construction management.

\section{c. Capacidades potenciais}

O terceiro grupo de habilidades principais corresponde às capacidades potenciais, que são necessárias para a participação de novos projetos e implementação de novas estratégias empresariais. Elas podem ser enumeradas como empreendedorismo e liderança dos chefes e gerentes ${ }^{8}$; valores e filosofia da empresa; aprendizagem e inovação da tecnologia, e quantidade e qualidade do recurso humano.

\section{Força}

S.10. A empresa conta com recurso humano, valores e uma filosofia empreendedora, capaz de afrontar novos desafios, como a internacionalização da companhia.

\footnotetext{
${ }^{8}$ Esta capacidade forma parte do segundo grupo de "habilidades básicas" de Linjie (2011), apesar de isso, o autor considerar que uma classificação mais de acordo com o enfoque do trabalho seria colocá-la no terceiro grupo.
} 


\section{Força}

S.11. A empresa conta com uma plataforma tecnológica capaz de aproveitar as inovações desta área.

Gibler et al. (2002) incrementa este grupo de habilidades com o subgrupo de globalização, o qual inclui o conhecimento de finanças e economia internacional, prestação de serviços globalizados, e conhecimento de línguas estrangeiras. Estes elementos seriam cruciais e indispensáveis para levar suas atividades a mercados internacionais.

\section{Força}

S.12. A empresa conta com habilidades para a prestação de serviços em áreas internacionais: gerencia com domínio de outras línguas e conhecimento de finanças e economia internacional.

\subsection{Fraquezas (Weaknesses)}

Usando o mesmo esquema descrito no começo do capítulo, apresenta-se primeiramente as fraquezas para a ampliação do foco habitual de atuação, e posteriormente as que correspondem ao desempenho de seus negócios, deixando de lado as competências empresariais e focando a atenção nos elementos internos que prejudicariam conseguir os objetivos planejados.

\subsubsection{Em mercados internacionais}

Foram encontradas fraquezas em empresas internacionalizadas sob os seguintes tópicos: cultura organizacional, estrutura empresarial, controle gerencial e recursos disponíveis, sendo estes os campos onde as empresas enfrentarem os maiores problemas. 


\section{a. Cultura organizacional}

Vargas (2008) assemelha a experiência de uma empresa internacionalizada com a "Torre de Babel", a qual interatua com legislações, interesses políticos, costumes, normas culturais e práticas de trabalho diferentes em cada país, dificultando assim a atuação da empresa.

Neste ambiente, o primeiro elemento que apresenta uma barreira para 0 desempenho adequado das empresas é a cultura da empresa ou cultura organizacional. Entendo esta como o conjunto de experiências, hábitos, costumes, crenças e valores que caracterizam uma empresa que rege as atitudes e comportamentos das pessoas, influindo na comunicação entre eles, a forma de resolver conflitos, de cumprir promessas e de se relacionar com os clientes, fornecedores, parceiros, comunidades e sociedade em geral.

Por exemplo, o caso dos fracassos das parcerias entre grandes empresas de capital aberto e incorporadoras regionais no Brasil, entre os anos 2006 a 2010 deveu-se, em parte, às dificuldades evidentes na convivência pelas diferenças de cultura empresarial, influindo na tomada de decisões, gerenciamento de negócios, auditoria e controle dos processos internos. O diretor de uma construtora paulista no anonimato no artigo de FÉ (2012, p. 1) relata: "nossa cultura não foi aceita e a ingerência chegou no nível dos procedimentos operacionais, com imposição de práticas que não eram condizentes com o público-alvo nem com o que praticávamos".

\section{Fraqueza}

W.1. A cultura empresarial da companhia mostra muitos traços próprios da cultura "regional" que interferem no desenvolvimento das atividades de negócios com pessoas de outras partes e culturas.

No caso da empresa Embraer S.A. (URBAN; FLEURY, 2005), a interação desta com outras empresas permitiu a familiarização da convivência entre empresas de culturas diferentes (destaque-se uma joint-venture na China), alavancando o sucesso na 
formação de alianças estratégicas com companhias estrangeiras, ficando atualmente na quarta posição mundial em seu setor.

\section{Fraqueza}

W.2. A empresa nunca interagiu com empresas estrangeiras no desenvolvimento de seus negócios.

Entre os elementos internos necessários para a internacionalização de uma empresa, observamos a inclusão de uma cultura organizacional flexível, que consiga adaptar-se rapidamente à nova sociedade local. Especialmente no caso das empresas de serviços onde a produção de bens requer a presença do cliente -a sociedade- no processo (URBAN; FLEURY, 2005; FLORENTINO; GOMES, 2009).

\section{Fraqueza}

W.3. A empresa apresenta uma cultura organizacional fechada, sem desejos de mudanças ou novas experiências.

\section{b. Estruturas administrativas}

A teoria da contingência estrutural sugere que as empresas modifiquem suas estruturas de administração para responder às contingências do ambiente, obtendo assim, um melhor desempenho.

No momento de internacionalizar a empresa, esta deverá se adaptar às contingências ambientais e revisar seus modelos administrativos em termos de estrutura, gestão de pessoas e gestão do conhecimento segundo o tipo de atividades e o modo de entrada no mercado.

Embora esta teoria do ajuste tenha sido altamente criticada em seus fundamentos e pelas inconsistências com os estudos empíricos, Vargas (2008) resgata um ponto importante: o fato de estas inconsistências deverem-se a uma falta de visão integradora entre cultura empresarial e estratégia. 
Exemplo desta adaptação ao meio mostra-se na Embraer S.A, citada anteriormente, em que a área de recursos humanos mudou seu enfoque quando se internacionalizou, deixando sua gestão paternalista por outra gestão guiada "por resultados", assumindo uma configuração descentralizada com uma equipe de consultores internos que vão enfrentar os retos e transformações da empresa (URBAN; FLEURY, 2005).

Mesmo assim, tanto em ambientes internacionais como locais, as empresas podem precisar de reestruturações administrativas segundo seja requerido por suas atividades e tentar, com isto, melhorar seu desempenho com respeito à concorrência e fornecer um melhor produto a seus clientes.

\section{Fraqueza}

W.4. A empresa conta com uma estrutura administrativa rígida, desenhada unicamente para seu nicho de atuação.

\section{c. Controle gerencial}

O processo de internacionalização das atividades de uma empresa levaria consigo também mudanças no controle gerencial ${ }^{9}$, pelo aumento do escopo geográfico das operações em ambientes mais competitivos e dinâmicos (FLORENTINO; GOMES, 2009).

Assim, empresas de pequeno porte em contextos locais que utilizem sistemas de controle "familiar" mais informais baseados nas relações pessoais, em contextos internacionais deveriam usar controle ad-hoc, que promove o autocontrole de cada unidade com estruturas descentralizadas e de fácil implantação nas organizações que dificultam a formalização de procedimentos.

9 O controle gerencial permite certificar aos administradores que os recursos sejam obtidos e aplicados de forma eficaz na busca dos objetivos da organização, corrigindo seus erros e incrementando seus pontos fortes. O objetivo do uso destes sistemas é o goal cogruence, ou seja, fazer com que os objetivos das pessoas coincidam com os objetivos da organização (FLORENTINO; GOMES, 2009). 


\section{Fraqueza}

W.5. A empresa conta com sistemas de controle familiar mais informais e baseados nas relações pessoais.

Por outro lado, empresas de grande porte com controles burocráticos baseados em regras e normas rígidas, em contextos internacionais vão precisar de sistemas de controle por resultados, que são mais dinâmicos com a criação de centros de responsabilidade que são avaliados por seus resultados, dando maior autonomia a suas unidades de produção.

\section{Fraqueza}

W.6. A empresa conta com sistemas de controle burocráticos, baseados em regras e normas rígidas.

Tanto empresas de maior como de menor porte estariam obrigadas à formalização e padronização de seus procedimentos e técnicas para facilitar o controle em processos internacionais. Esta característica é distinguida por Paim (2009) entre o grupo de competências essenciais para empresas internacionalizadas com o nome de "processos confiáveis".

Assim, processos e procedimentos estabelecidos poderiam servir para o mapeamento na avaliação de parceiros, com o objetivo de formar alianças estratégicas, segundo se concluiu da experiência do Grupo Thá que trabalhou em parceria com a incorporadora Rossi (FÉ, 2012).

\section{Fraqueza}

W.7. A empresa não conta com procedimentos formalizados e padronizados que pudessem ser replicados no estrangeiro por subsidiárias. 
Ademais, para acompanhar estes procedimentos e o cumprimento dos resultados, serão precisas ferramentas para a avaliação da administração local, como relatórios. Eles representam uma maneira de resumir o desempenho das diferentes unidades e aplicar medidas corretivas nos sistemas de produção.

\section{d. Disponibilidade de recursos financeiros}

Por último, um elemento estratégico que dever ser considerado na análise do processo de internacionalização é a quantidade e disponibilidade de recursos financeiros que a empresa dispõe para desenvolver esta estratégia. Considera-se, portanto, que ao início desse processo se precisaria de investimentos consideráveis para cobrir os custos de entrada e instalação no novo mercado.

Pouca disponibilidade de recursos pode levar a atuações insuficientes para enfrentar as demandas do novo mercado e o agir da concorrência local frente aos novos competidores.

\section{Fraqueza}

W.8. Recurso financeiro limitado para internacionalizar a empresa.

\subsubsection{Em mercados locais}

Da experiência de diversificação de produtos e de mercados comentada anteriormente, Souza (2011) identificou o predomínio do uso de parcerias, na maioria das empresas de grande porte que se abriram ao mercado de capitais, um modelo de ágil implementação, e que não requerem um redesenho organizacional, nem tempo para que operem com eficiência como outros tipos de alianças estratégicas.

Mas no ciclo da implantação destes modelos de parceria "houve uma destruição de recursos que não se revelou criadora" ou cara demais, mostrando que os recursos 
que poderiam ser alocados em investimento, em pesquisa e desenvolvimento para criar competências nestes modelos não foram aproveitados (ALENCAR, 2012).

\section{Fraqueza}

W.9. A empresa não consegue desenvolver novas competências, ou as fazem a preços altos demais, especialmente nos modelos de parceiras e outras alianças estratégicas.

Além disto, várias empresas apresentaram carência e descuidos nas competências inerentes às empresas de real estate na execução destas estratégias de expansão, como na avaliação da qualidade dos investimentos; condução das análises e gestão dos riscos dos negócios, e habilidades no gerenciamento de projetos (project management). Em detrimento disso há "perda de controle, descumprimento de prazos, custos acima do orçamento, queda na qualidade dos empreendimentos, redução de margens e, por fim, encerramento de sociedades que não deram certo" (FÉ, 2012, p.1).

Como se comentou na seção 3.1.2., estas competências básicas são necessárias para levar com sucesso os projetos nos ambientes conhecidos. Por tal, seriam indispensáveis para incursões com maior risco, como a internacionalização da companhia.

\section{Fraqueza}

W.10. A empresa carece de algumas das competências básicas próprias das empresas de real estate residencial. 


\section{ANÁLISE DO MERCADO RESIDENCIAL COSTARRIQUENHO: OPORTUNIDADES E AMEAÇAS (OPPORTUNITIES AND THREATS)}

No presente capítulo se apresenta a segunda parte da análise de uma possível expansão de empresas brasileiras de real estate residencial no mercado costarriquenho, com o estudo do mercado residencial costarriquenho e outras forças exógenas que neste incidem, distinguiram-se os elementos que poderiam ser atrativos ou prejudiciais para o desempenho das empresas estrangeiras.

Analisou-se o ambiente macroeconômico e as principais conjunturas políticas-legais e socioculturais do país, como também os sistemas de financiamento, o nível de absorção do mercado, a oferta competitiva e as características gerais do mercado costarriquenho.

Como no capítulo anterior, cada fator estratégico distinguido na análise será sintetizado e apresentado dentro de uma caixa de texto.

\subsection{Ambiente macroeconômico}

A Crise Econômica Mundial de 2008 marcou um ponto crucial na economia costarriquenha, esta crescia na média de 5,3\% por ano, chegando nos últimos dez anos a ser 62\% superior à economia de 1998. Mas, para o ano de 2009, foi oficialmente confirmada a recessão econômica no país (ver Tabela 4.1 e Figura 4.1), com a queda da produção interna e uma contração da economia segundo o Banco Central da Costa Rica (BCCR) (MINISTÉRIO DE MORADIA E ASSENTAMENTOS HUMANOS, 2012a).

Tipicamente, a economia costarriquenha depende das grandes economias internacionais, especialmente daquelas que têm apresentado uma condição instável nos últimos anos. Do total das exportações, 50\% são alocadas nos mercados dos Estados Unidos e da União Europeia, sendo estas economias também o foco de outros setores como turismo e serviços (principalmente "call center"), ambos 
importantes motores da economia costarriquenha (PROGRAMA ESTADO DA NAÇÃO, 2012; 2013).

Tabela 4.1 - PIB e taxas de variação do período 2007-2013

\begin{tabular}{|c|c|c|c|c|c|c|c|c|}
\hline \multirow[b]{2}{*}{ Indicador } & \multicolumn{7}{|c|}{ Ano } & \multirow[b]{2}{*}{$2014^{\star \star \star}$} \\
\hline & $2007^{\star *}$ & $2008^{\star \star}$ & 2009 & 2010 & 2011 & $2012^{* *}$ & $2013^{\star *}$ & \\
\hline $\begin{array}{l}\text { PIB a preços de } \\
\text { mercado em } \\
\text { milhões de US\$ }\end{array}$ & 26.322 & 29.838 & 29.383 & 36.298 & 41.237 & 45.375 & 49.621 & --- \\
\hline $\begin{array}{l}\text { Regime de } \\
\text { câmbio médio } \\
\text { de contas } \\
\text { nacionais }\end{array}$ & 516,62 & 526,24 & 573,29 & 525,83 & 505,66 & 502,9 & 499,77 & --- \\
\hline $\begin{array}{c}\text { Taxa de } \\
\text { variação do PIB } \\
\text { Real* }^{\star}\end{array}$ & $7,94 \%$ & $2,73 \%$ & $-1,02 \%$ & $4,95 \%$ & $4,51 \%$ & $5,13 \%$ & $3,50 \%$ & $3,58 \%$ \\
\hline
\end{tabular}

$(*)$ A preços constantes desde $1991\left(^{* *}\right)$ cifras preliminares.

$\left({ }^{* * *}\right)$ Projeção aprovada pela Junta Diretiva do BCCR.

Fonte: Produção do próprio autor com os dados do Banco Central de Costa Rica (2014).

Somado a isso, o país depende de produtos importados para sua indústria local, insumos como aço, cobre e outro minerais. Ademais, da influência do preço internacional do petróleo sobre o preço final da produção local.

\section{Ameaça}

T.1. O país tem uma economia suscetível aos acontecimentos globais e depende dos mercados norte-americanos e europeus.

Ainda com esta dependência dos mercados internacionais, o BCCR com a atual política monetária de "metas de inflação" tem conseguido manter a inflação dentro das bandas estabelecidas, na faixa de 4-6\% (PROGRAMA ESTADO DA NAÇÃO, 2012). Ficando o Índice de Preços ao Consumidor (IPC) em 3,68\% no ano de 2013 , o mais baixo em 37 anos de registros do BCCR (LEITÓN, 2014).

\section{Oportunidades}

O.1. A economia costarriquenha apresenta uma inflação estável, nos últimos cinco anos o IPC mantém-se na faixa de 4-6\%, segundo o estabelecido pela atual política monetária. 
Para o ano de 2010 a Costa Rica começa sua recuperação econômica caracterizada por uma alta volatilidade e oscilações dos indicadores econômicos dentro do mesmo ano, ante as incertezas e ações dos mercados internacionais. Mas apesar disso, os resultados anuais são favoráveis desde a recuperação, e para os anos 2010 a 2013, o crescimento do PIB (ver Tabela 4.1) manteve-se acima da média para America Latina (3,1\%) (PROGRAMA ESTADO DA NAÇÃO, 2012; 2013). O Índice Mensal de Atividade Econômica (IMAE) mostra a recuperação, a volatilidade e as oscilações da economia antes descritas (ver Figura 4.1).

Figura 4.1 - Variação interanual do IMAE

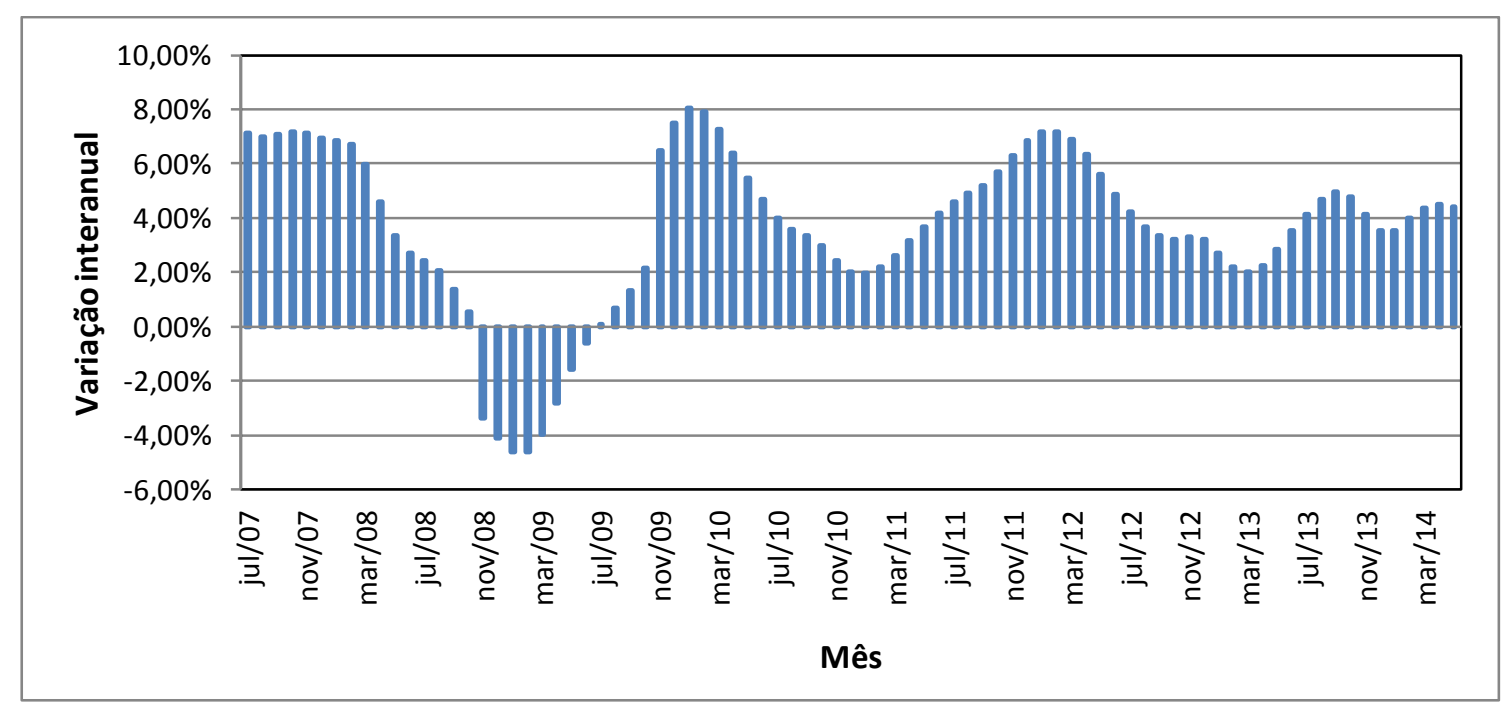

Nota: variação percentual do nível do mês respeito ao mesmo mês do ano anterior.

Fonte: Produção do próprio autor com dados do Banco Central da Costa Rica (2014).

\section{Ameaça}

T.2. Um país com uma economia em recuperação após a Crise Mundial de 2008, mas ainda sem uma estabilidade consolidada ante as incertezas e ações dos mercados internacionais.

Mas apesar desses resultados, a recuperação econômica é considerada frágil por não estar consolidada por fatores internos, limitando a capacidade de resposta ante outra crise. A situação fiscal e a dívida do Governo Central preocupam vários setores produtivos, pelo risco envolvido para a sustentabilidade e solvência econômica nacional (PROGRAMA ESTADO DA NAÇÃO, 2012). 
Em fevereiro de 2014, o montante da dívida pública foi de US\$26.502 milhões (49.5\% do PIB), dos quais $71,9 \%$ do total corresponde à dívida interna e $28,1 \%$ à dívida externa. Em fevereiro do ano passado a dívida foi de 48,8\% do PIB (CONSELHO MONETARIO CENTROAMERICANO, 2013). Os efeitos em curto prazo podem ser refletidos na diminuição do investimento social e infraestrutura, em pouca criação de emprego, e na pressão nas taxas de juros e inflação em alta.

\section{Ameaça}

T.3. Um país com um crescimento da dívida do setor público nos últimos anos que poderia afetar a sustentabilidade e solvência econômica nacional, influindo nas taxas de juros e inflação em alta.

Internacionalmente a economia costarriquenha fica na posição 80 em qualidade do ambiente macroeconômico, entre 148 economias, segundo o "Relatório Global de Competitividade" (WEFORUM, 2013). No ranking "Doing Business" (Fazer Negócios) passou da posição 117 em 2009 para 102 em 2014, entre 189 países (INTERNACIONAL FINANCE CORPORATION, 2013).

\subsubsection{Investimento Estrangeiro Direto}

Indicadores como o Investimento Estrangeiro Direto (IED) mostraram uma recuperação no ano de 2011, e no ano passado foi registrado o maior valor total da década, muito a ver com o aporte das atividades imobiliárias que mostraram um crescimento abrupto, duplicando os valores obtidos nos anos anteriores (ver Tabela 4.2).

\section{Oportunidades}

O.2. Economia local com um importante e crescente investimento estrangeiro direto, especialmente em atividades imobiliárias. 
Tabela 4.2 - Total de IED período 2007-2012

\begin{tabular}{cccccccc}
\hline Setores & $\mathbf{2 0 0 7}$ & $\mathbf{2 0 0 8}$ & $\mathbf{2 0 0 9}$ & $\mathbf{2 0 1 0}$ & $\mathbf{2 0 1 1}$ & $\mathbf{2 0 1 2}$ & $\mathbf{2 0 1 3}$ \\
\hline Manufatura & 689,2 & 554,7 & 407,3 & 965,9 & 737,4 & 634,4 & 343,8 \\
\hline Serviços & 57,5 & 145,4 & 241,5 & 85,4 & 622,9 & 916,8 & 823,9 \\
\hline $\begin{array}{c}\text { Turismo } \\
\begin{array}{c}\text { Atividades } \\
\text { imobiliárias }\end{array}\end{array}$ & 321,3 & 291,5 & 253,6 & 81,0 & 113,5 & 143,0 & 139,7 \\
$\begin{array}{c}\text { Total IED na } \\
\text { economia } \\
\text { declarante }\end{array}$ & $\mathbf{1 . 8 9 6 , 1}$ & $\mathbf{2 . 0 7 8 , 2}$ & $\mathbf{1 . 3 4 6 , 5}$ & $\mathbf{1 . 4 6 5 , 6}$ & $\mathbf{2 . 1 7 8 , 4}$ & $\mathbf{2 . 3 3 2 , 3}$ & $\mathbf{2 . 7 1 4 , 2}$ \\
\hline Milhões de dólares & & & & & & &
\end{tabular}

*Milhões de dólares

Fonte: Produção do próprio autor com os dados do Banco Central de Costa Rica (2014).

\subsubsection{Emprego e pobreza}

Apesar da suposta recuperação econômica, a taxa de desemprego vem crescendo nos últimos anos (ver Tabela 4.3). Ademais, tem-se gerado brechas salariais entre trabalhadores nos últimos anos, produzindo um aumento na desigualdade entre seus habitantes, mostrando um aumento gradual no coeficiente de Gini ${ }^{10}$ (PROGRAMA ESTADO DA NAÇÃO, 2013).

Tabela 4.3 - Taxa de desemprego aberto, período 2006-2013

\begin{tabular}{|c|c|c|c|c|c|c|c|c|}
\hline & 2006 & 2007 & 2008 & 2009 & 2010 & 2011 & 2012 & 2013 \\
\hline $\begin{array}{l}\text { Taxa de desemprego } \\
\text { aberto }\end{array}$ & 6,0 & 4,6 & 4,9 & 7,8 & 7,3 & 7,7 & 7,8 & 8,5 \\
\hline
\end{tabular}

Assim também, mantém-se o estancamento da pobreza e pobreza extrema desde 1994, com $20 \%$ +/- 1,5 ponto percentual a pobreza, e em $6 \%$ +/- 1,0 ponto percentual a pobreza extrema (PROGRAMA ESTADO DA NAÇÃO, 2012; 2013).

\section{Ameaça}

T.4. Um país sem melhoria nos indicadores sociais, com indicadores como desemprego e desigualdade crescentes nos últimos anos.

${ }^{10} \mathrm{O}$ coeficiente Gini é uma medida usada para quantificar a desigualdade na distribuição das rendas. Tem valores entre 0 e 1, no qual 0 é a perfeita igualdade, todos com os mesmos ingressos, e 1 corresponde à perfeita desigualdade (PROGRAMA ESTADO DA NAÇÃO, 2013). 


\subsubsection{Regime de câmbio: dólar - colóns}

O regime de câmbio da Costa Rica é regido por "bandas cambiais" estabelecido em 17 de outubro de 2006. Nesse sistema o valor do dólar é determinado pelas faixas estabelecidas pelo BCCR, com um teto inicial de 530 colóns por dólar e um piso de 514 colóns. Na atualidade, o piso está fixo em 500 colóns (desde julho 2008) e o teto em 800 colóns. Essas bandas se mantêm pela intervenção do BCCR com a compra e venda de divisa estrangeira (SOTO, 2013).

Nos últimos anos, o regime de câmbio se manteve no limite inferior da banda cambial sem maiores mudanças, sendo trabalhoso ao BCCR mantê-lo neste valor, devido à apreciação do colón frente ao dólar, com a entrada de capitais estrangeiros pela queda nas taxas de juros internacionais (capital especulativo), a pressão fiscal (com a venda de títulos de dívida), o crescimento nas exportações e serviços, o aumento do fluxo de capital de IED e a maior demanda de moeda local (PROGRAMA ESTADO DA NAÇÃO, 2012).

Mas no começo de 2014, pela condição de déficit fiscal do governo central, especulação pela mudança de governo em ano eleitoral e mudanças nas taxas de juros da Reserva Federal dos Estados Unidos, o dólar teve uma apreciação abrupta frente ao colón (ver Figura 4.2), com o que foram questionadas as políticas e intervenções do BCCR, de não serem claras e afetarem certos setores da economia.

Figura 4.2 - Regime de câmbio (preço de compra) 2013-2014

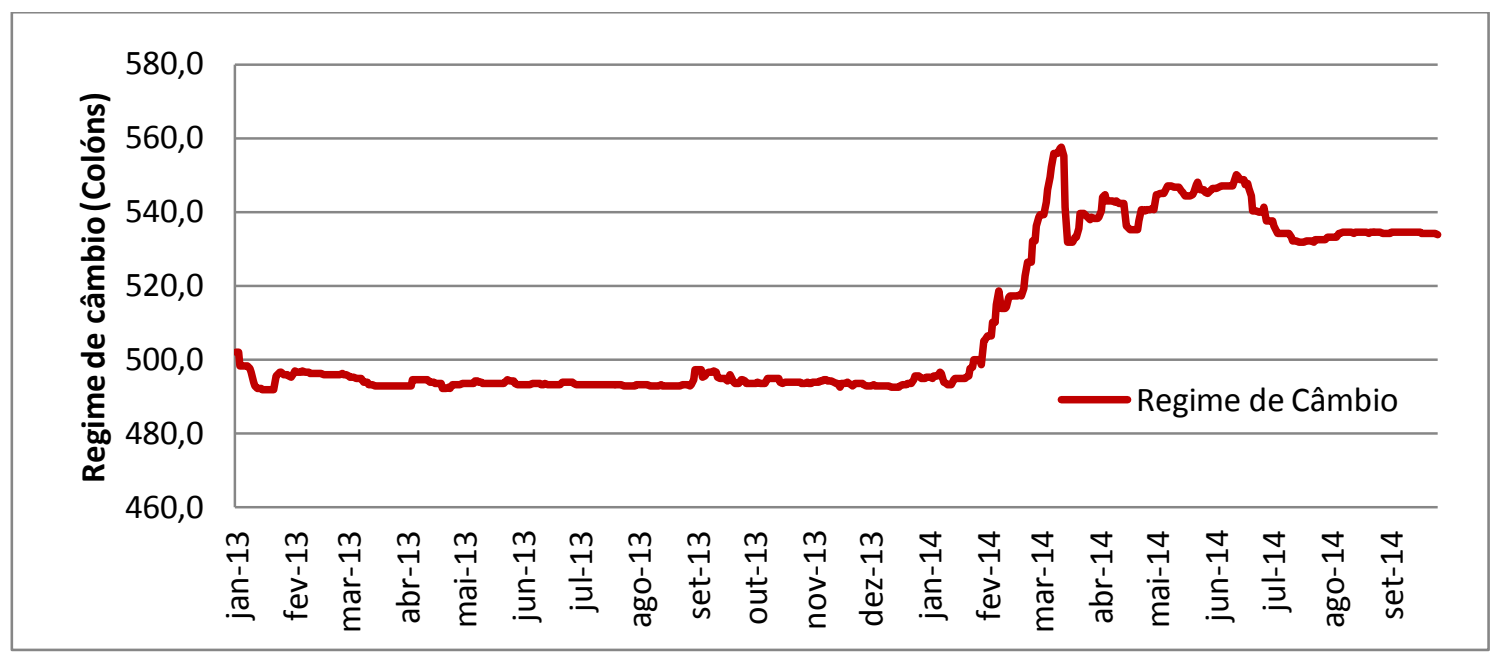

Fonte: Produção do próprio autor com dados do Banco Central da Costa Rica (2014). 


\section{Ameaça}

T.5. Embora a Costa Rica tenha políticas de bandas cambiais, com tetos e pisos fixos, em curto tempo pode haver mudanças abruptas do regime de câmbio da moeda local frente ao dólar por condições exógenas.

\subsection{Conjunturas político-legais}

A Costa Rica conta com um sistema político estável. Entre as características do país distinguem-se a abolição do exército desde $1^{\circ}$ de dezembro de 1948 e a transparência institucional, especialmente a independência do Poder Judicial (MINISTÉRIO DE MORADIA E ASSENTAMENTOS HUMANOS, 2012a). No Global Democracy Ranking 2013 situa-se na posição 31 acima do Brasil (44) (GLOBAL DEMOCRACY RANKING, 2014).

\section{Oportunidades}

O.3. País com grande estabilidade política e transparência institucional.

Entre as políticas influentes sobre mercado residencial costarriquenho destaca-se a "Política Nacional de Ordenamento Territorial 2012 a 2040" (PNOT) de acordo com "Plano Nacional de Desenvolvimento 2011-2014 María Teresa Obregón Zamora".

Esta política de ordenamento territorial visa promover os assentamentos humanos e as atividades econômicas e sociais para o bem-estar da população, como o uso dos recursos naturais e a conservação do meio ambiente, como ferramenta de planejamento estratégico a longo prazo, sob três eixos principais: qualidade do habitat; proteção e gestão do ambiente, e competitividade territorial.

Com essas políticas vem sendo criadas ferramentas de desenvolvimento para o ordenamento territorial em todo o país, reforçando as prefeituras, simplificando a obtenção dos alvarás de construção, e a atualização da legislação e mecanismos 
jurídicos para o estabelecimento de Parcerias Público-Privadas (PPP) e operações urbanas.

\section{Oportunidades}

O.4. Criação de políticas que promovem os assentamentos humanos e o ordenamento territorial, simplificando os alvarás de construção, atualizando a legislação e incentivando as PPP e operações urbanas.

Outra política que tem grande importância para os projetos residências da Costa Rica é "O Plano de Ordenamento Territorial da GAM 2011-2030 (POT/GAM)". Esta tem impacto sobre uma região economicamente importante e com alta densidade populacional como é a Grande Área Metropolitana (GAM) ${ }^{11}$, e tem como objetivo "um crescimento urbano racional, evitando a dispersão, a baixa densidade e o uso sub- ótimo da infraestrutura; e que se integre e respeite o meio natural existente" (MINISTÉRIO DE MORADIA E ASSENTAMENTOS HUMANOS, 2012b, p. 24).

Assim, pretende-se mudar a cidade em uma metrópole eficiente, funcional, competitiva e integral com o meio ambiente, para potencializar seu rol como principal núcleo urbano do país, estimulando o uso do solo nos principais centros urbanos e restringindo os desenvolvimentos em zonas de risco. Incentivando projetos residenciais compactos de alta densidade, que interatuem com a cidade de maneira sustentável.

\section{Oportunidades}

O.5. Criação de políticas que incentivam o uso do solo nos principais centros urbanos, dando preferência aos projetos residenciais de alta densidade que interatuem com o entorno da cidade e meio ambiente.

Essas ações políticas vêm a consolidar antigas iniciativas como o "Programa de Regeneração e Repovoamento do São José" (COSTA RICA, 2004), que teve como origem a promoção da renovação do Centro do São José, devido à deterioração,

\footnotetext{
${ }^{11}$ As características da GAM vão ser apresentadas na secção 4.5.1.
} 
abandono e obsolescência em que se encontrava antes desta legislação, além de reverter o processo de despovoamento especialmente nos centros urbanos deprimidos.

Com a moradia como uns dos eixos principais, este Programa tem por objetivo estabelecer:

"[...] situações que incentivem os investimentos no centro da cidade, de maneira que as instituições bancárias, públicas e privadas, assim como outras instituições financeiras, possam criar programas especiais de financiamento, para projetos dirigidos ou patrocinados pelo Programa." (COSTA RICA, 2004, p. 4, tradução nossa)

Também facilitar o processo, ao

“[...] resguardar a gestão, dentro da Administração Pública, de mecanismos ou convênios facilitadores de crédito, alvarás e investimento, para projetos que se inscrevam dentro do processo de renovação urbana." (COSTA RICA, 2004, p. 5, tradução nossa)

\section{Oportunidades}

O.6. Criação de políticas que incentivam os investimentos para a renovação urbana do centro da capital (região de maior população), facilitando os créditos para as empresas e agilizando os alvarás de construção.

Os incentivos são tangíveis para aquelas empresas de real estate que alinham seus produtos com os objetivos do Programa, muitas destas incorporadoras conseguem ser exoneradas do pagamento das taxas de construção na prefeitura de São José e são favorecidas com o aumento do potencial construtivo do terreno quando os projetos são amistosos com o ambiente (BARRANTES, 2012).

\section{Oportunidades}

O.7. Criação de políticas que influenciam diretamente na gestão dos projetos residenciais com exoneração das taxas de construção nas prefeituras e aumentos dos Coeficientes de Aproveitamento do Solo (CAS) em projetos sustentáveis com o meio ambiente. 
Apesar desses esforços políticos, segundo os dados do Ministério da Moradia e Assentamentos Humanos (2012a) só $17,08 \%$ do total do território continental do país está sob a legislação urbanística, realçando que só a GAM conta com um plano de desenvolvimento urbano com diretrizes específicas e um marco referencial para suas prefeituras. Assim, pouco mais da metade (41 das 81 ) das prefeituras do país tem alguma ferramenta de "planos reguladores" para este fim, os quais muitos destes apresentam sérias deficiências, desatualizações, entre outros problemas.

\section{Ameaça}

T.6. Legislação urbanística com deficiências, desatualizações e pouca abrangência do território local.

Além do ordenamento territorial, o país está investindo no melhoramento de sua competitividade, com a criação do "Conselho de Competitividade e Inovação", que trabalha em cinco áreas: regulação e alvarás, desenvolvimento de infraestrutura, financiamento de mercado de capitais, comercio exterior e investimento estrangeiro direto; desenvolvimento do capital humano e inovação (VINDAS, 2010).

O Ministério da Economia, Indústria e Comércio (MEIC) trabalham em convênios internacionais para melhorar a competitividade da região ligada com o meio ambiente, e fazem acordos para a aplicação de modelos de eficiência governamental, negócios e infraestrutura. Também fazem cooperações diretas com o Banco Mundial (BM) para melhorar o ambiente de investimento local (MINISTÉRIO DE MORADIA E ASSENTAMENTOS HUMANOS, 2012a; 2013b).

No ranking "Doing Business" o país passou de 109 em 2013 para 102 em 2014 entre 189 países, avançando significativamente em matéria de "gestão de alvarás de construção" e "abertura de um negócio" (INTERNACIONAL FINANCE CORPORATION, 2013). Também, segundo "The Global Competitiveness Index" (Índice de Competitividade Global) a Costa Rica fica na posição 54 entre 148 países, e na quarta posição no top 10 da America Latina e Caribe, acima do México e do Brasil (WEFORUM, 2013). 


\section{Oportunidades}

O.8. Criação de políticas que promovem a competitividade do país em termos de: regulações, alvarás de construção, infraestrutura, financiamento, investimento local, eficiência governamental, investimento estrangeiro direto, desenvolvimento do capital humano e inovação.

Apesar dessas políticas, o país apresenta deterioração e atraso em termos de infraestrutura rodoviária, portuária e aeroportuária, sendo gargalos destacáveis para o desenvolvimento e competitividade no país (VINDAS, 2010; PROGRAMA ESTADO DA NAÇÃO, 2012).

\section{Ameaça}

T.7. O país apresenta gargalos de competitividade ligados à deterioração e atraso na infraestrutura rodoviária, portuária e aeroportuária.

\subsubsection{Alvarás de construção}

Na parte legal, a Costa Rica vem-se caracterizando por entraves burocráticos nos processos produtivos, sendo identificados 41 alvarás que são muito complexos para esse âmbito (MINISTÉRIO DA MORADIA E ASSENTAMENTOS HUMANOS, 2012a). Afetando os processos de planejamento e execução dos projetos em todas as áreas, em particular o setor construção.

\section{Ameaça}

T.8. País com entraves legais e burocráticos nos processos produtivos.

Por isso, o governo da república da Costa Rica vem trabalhando em políticas com o fim de acionar e melhorar o uso dos recursos públicos, para promover simplificação dos alvarás e procedimentos na administração pública e aumentar a 
competitividade do país. Entre as principais concretizações nos últimos anos estão (MINISTÉRIO DA ECONOMIA, INDÚSTRIA E COMERCIO, 2013):

- A lei $N^{\circ}$ 8220: "Proteção ao Cidadão do Excesso de Requisitos e Formalidades Administrativas".

- O decreto N³6550-MP-MIVAH-S-MEI "Regulamentos para a Formalidade de Revisão dos Planos para a Construção" ${ }^{12}$.

- O site de consulta pública www.tramitesconstruccion.go.cr.

Além disso, está sendo trabalhada a ligação entre as principais instituições públicas e prefeituras para agilizar os alvarás de construção e aumentar a qualidade do serviço pelas vias virtuais e da internet.

No ranking do Doing Business 2014 a Costa Rica ascendeu 37 posições na classificação "Obtenção de alvarás de construção", ficando na posição 82, entre 189 economias (INTERNACIONAL FINANCE CORPORATION, 2013).

\section{Oportunidades}

O.9. Criação de políticas para agilizar os alvarás de construção e formalidades nas instituições públicas, e aumentar a qualidade do serviço e a informação pelas vias virtuais.

\subsection{Conjunturas socioculturais}

Os fatores socioculturais como língua, costumes, nível e conteúdo educacional, compreensão dos problemas, estabelecimento de prioridades, cumprimento de promessas e práticas de negócios, variam de país para país, influenciando o desempenho das empresas e suas estratégias de atuação (e.g. na formação de alianças estratégicas), afetando o dia a dia de suas atividades (URBAN; FLEURY, 2005; FLORENTINO; GOMES, 2009).

\footnotetext{
${ }^{12}$ Textos originais: "Protección al Ciudadano del Exceso de Requisitos y Trámites Administrativos" e "Reglamentos para el Trámite de Revisión de los Planos para la Construcción".
} 
Em uma entrevista ${ }^{13}$ com José Rui Prudencio, empresário brasileiro e empreendedor de negócios na Costa Rica, ex-dono de uma reconhecida marca de restaurantes de comida brasileira, e agora na indústria de bebidas, comenta que não há grande diferença entre fazer negócios na Costa Rica e fazer negócios no Brasil.

Segundo o relatório da "Agenda Nacional de Competitividade, Costa Rica 20062016", emitida pelo Conselho Nacional da Competitividade, várias das conjunturas socioculturais poderiam ser aproveitadas pelas empresas internacionais, a saber:

- a qualidade da educação, ficando com os índices de alfabetização similares a países desenvolvidos;

- recurso humano especializado;

- centros de pesquisa e desenvolvimento;

- modernização e inovação empresarial (MINISTÉRIO DA MORADIA E ASSENTAMENTOS HUMANOS, 2012a, p. 70).

\section{Oportunidades}

O.10. País com nível educacional alto, recurso humano especializado e centros de pesquisa e desenvolvimento.

\subsection{Outros aspectos do país}

Entre outros aspectos a realçar que podem influenciar no desempenho das empresas de real estate residencial estão:

- Localização estratégica, especialmente para o acesso ao mercado dos Estados Unidos e outros mercados internacionais (MINISTÉRIO DA MORADIA E ASSENTAMENTOS HUMANOS, 2012a).

- Baixa proteção para o investidor minoritário em sociedades anônimas: segundo a classificação do Doing Business 2014, a Costa Rica está na posição 170/189 dos países em proteção aos investidores (INTERNACIONAL FINANCE CORPORATION, 2013).

\footnotetext{
${ }^{13}$ Entrevista realizada na nova planta de bebidas do Grupo Mix, Alajuela, Costa Rica no dia 17 de outubro de 2013.
} 
- Alto risco pelos fenômenos naturais: $36,8 \%$ da superfície continental do país está exposta a três ou mais fenômenos naturais e $80,1 \%$ do PIB está em zona de alto risco de diversos tipos de desastres (MINISTÉRIO DA MORADIA E ASSENTAMENTOS HUMANOS, 2012a).

- Uma deteriorada e atrasada infraestrutura rodoviária, portuária e aeroportuária, como se comentou anteriormente (PROGRAMA ESTADO DA NAÇÃO, 2012).

\section{Oportunidades}

O.11. País com localização estratégica para entrar no mercado norte-americano e outros blocos econômicos importantes.

\section{Ameaça}

T.9. Baixa proteção para o investidor minoritário em sociedades anônimas.

\section{Ameaça}

T.10. Alto risco pelos fenômenos naturais: $36,8 \%$ da superfície continental do país está exposta a três ou mais fenômenos naturais.

Florentino e Gomes (2009) chamam a atenção para o sistema legal do mercado estrangeiro. Entre os elementos a avaliar estaria: direitos de propriedade, obrigatoriedade de cumprimento de contratos, relações trabalhistas, entre os mais importantes. Em nosso caso específico, esses elementos não apresentam oportunidade ou ameaça relevante, precisando de antemão o conhecimento desta informação no caso de uma atuação internacional. 


\subsection{Mercado residencial}

Nesta seção são analisadas as características gerais do mercado residencial costarriquenho e os elementos mais relevantes de ordem estratégica, a saber: recursos para o financiamento de empreendimentos residenciais, o nível de absorção do mercado e a oferta competitiva.

\subsubsection{Descrição geral}

O país administrativamente está dividido em províncias ${ }^{14}$, estas em municípios e os municípios em distritos (GOBIERNO DE COSTA RICA, 1949). Atualmente, o país tem sete províncias, a saber: São José (capital), Cartago, Alajuela, Heredia, Guanacaste, Puntarenas e Limón.

O país conta com 81 municípios, estes possuem a importância, outorgada pelos artigos 169 e 170 da Constituição da Costa Rica, de contar com um governo local ou prefeitura, que administra os interesses locais e serviços do município. Sendo os primeiros entes de administração territorial e com autonomia para o planejamento e controle do desenvolvimento urbano dentro de seus limites territoriais (MINISTÉRIO DA MORADIA E ASSENTAMENTOS HUMANOS, 2012a; 2013a).

Para o planejamento do desenvolvimento nacional, o país se divide também em regiões, baseadas nas grandes características naturais e socioculturais, estas são: Central, Chorotega, Brunca, Huetar Atlántica e Huetar Norte (INSTITUTO DE FOMENTO E ACONSELHAMENTO MUNICIPAL, 2003; MINISTÉRIO DA MORADIA E ASSENTAMENTOS HUMANOS, 2012a).

\footnotetext{
${ }^{14}$ Similar aos estados no Brasil, entretanto nas províncias não há nenhuma independência jurídica nem legislativa, por não ser uma república confederativa, assim como o Brasil.
} 
Figura 4.3 - Localização da Costa Rica

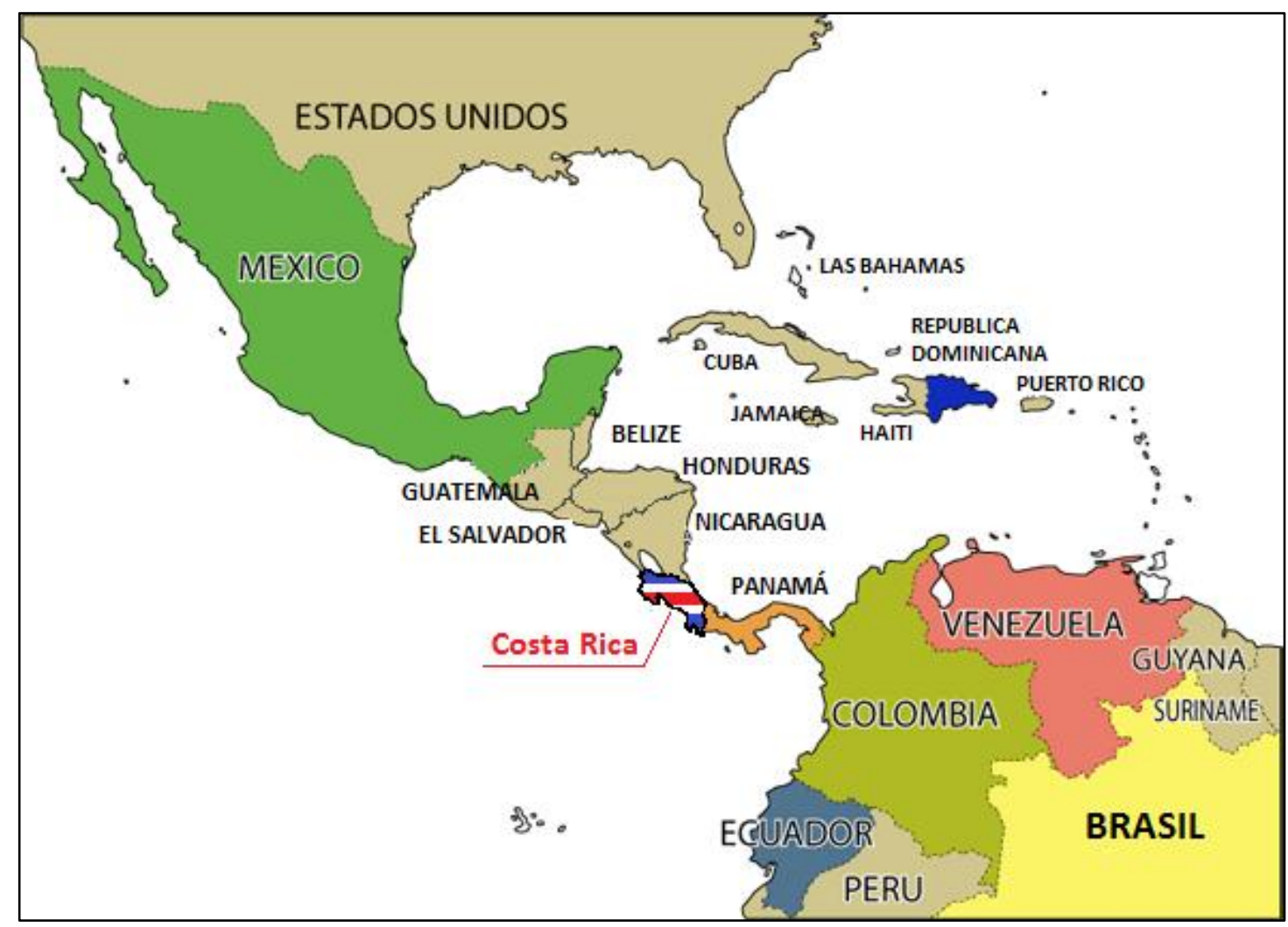

Fonte: <http://viajarfull.com/mapa-de-centroamerica/> data de acesso 12/11/2014, modificado pelo autor.

No país, a maior concentração de população, infraestrutura, e atividades econômicas e administrativas são dadas na região Central, pela localização estratégica no desenvolvimento do país, atraindo a maioria de indústrias, comércios e serviços. Nessa região se constituiu a "Grande Área Metropolitana" (GAM), devido à configuração histórica, proximidade e ligação das quatro principais cabeças de província do país (São José, Alajuela, Cartago e Heredia) (ver Figura 4.4). Essa região conta com 31 municípios (INSTITUTO DE FOMENTO E ACONSELHAMENTO MUNICIPAL, 2003).

Essa sub-região tem uma grande importância econômica, concentrando os maiores e mais importantes serviços e atividades, formando parte das mudanças nos processos econômicos, sociais e culturais do país. Embora abranja 4,0\% do território nacional, produz $70 \%$ do PIB do país (MINISTÉRIO DA MORADIA E ASSENTAMENTOS HUMANOS, 2012a). 
Figura 4.4 - Localização da GAM na Costa Rica

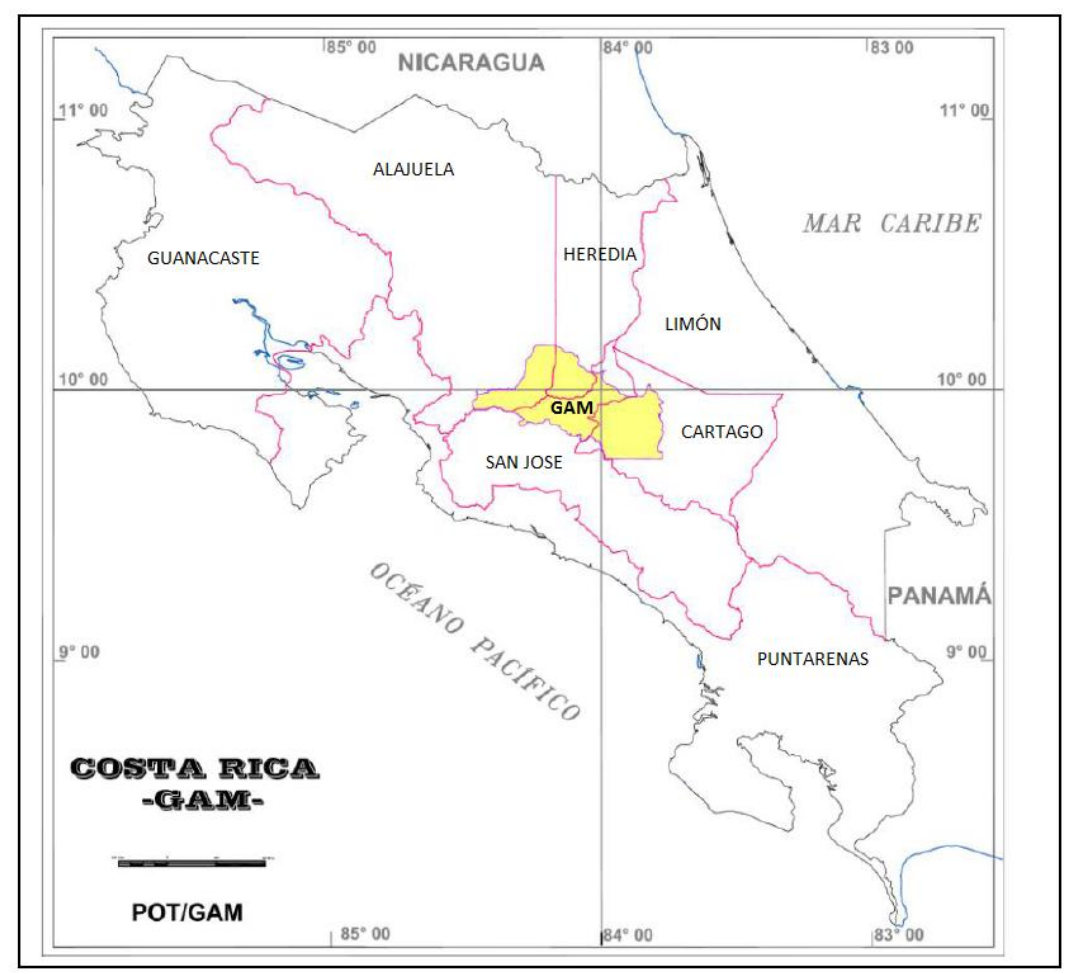

Fonte: Ministério de Moradia e Assentamentos Humanos (2012b, p.16), modificado pelo autor.

A GAM é a região mais urbanizada, conta com municípios $100 \%$ urbanos e com os maiores níveis de desenvolvimento social (FUNDAÇÃO PROMOTORA DE MORADIA, 2012). Além disso, tem os assentamentos mais antigos do país, desde do início de sua colonização, para depois voltar para uma migração das zonas agrícolas ao centro (INSTITUTO DE FOMENTO E ACONSELHAMENTO MUNICIPAL, 2003).

\section{Oportunidades}

O.12. O país concentra a maior parte da população e atividades econômicas no centro do país, favorecendo a centralização das atividades das empresas residenciais em uma determinada área.

Assim, o sistema urbanístico da Costa Rica está estabelecido hierarquicamente como:

- A GAM;

- Cidades intermédias (entre 50.000 e 200.000 habitantes); 
- Cidades pequenas (menos de 50 mil habitantes).

Esse sistema está caracterizado por um desenvolvimento linear ao longo dos eixos de comunicação entre cidades, e de baixa densidade, menores de 200 hectares/pessoa (MINISTÉRIO DA MORADIA E ASSENTAMENTOS HUMANOS, 2012a).

\subsubsection{Características gerais}

Entre as características gerais mais importantes do mercado residencial costarriquenho destacam-se: os diversos segmentos de renda, os fatores de propriedade, o estado das moradias, o déficit habitacional, o estoque residencial, as mudanças demográficas e a cultura instalada.

\section{a. Segmentos de renda}

Para a segmentação de renda, utilizou-se primeiramente a informação da "Enquete Nacional de Lares" (ENAHO) 2013. Considerando-se como elemento de estudo o "lar", independente das pessoas e da composição deste. Todos os lares do país foram divididos por renda média em cinco quintis ou cinco grupos com a mesma quantidade de lares, como se mostra na Tabela 4.4.

Tabela 4.4 - Segmentos de renda segundo ENAHO 2013

\begin{tabular}{ccccccc}
\hline & & \multicolumn{5}{c}{ Quintil de renda per capita } \\
\hline Características & Total & I & II & III & IV & V \\
\hline Total de pessoas & 4.709 .161 & 1.049 .166 & 1.035 .489 & 979.532 & 859.826 & 785.148 \\
\hline Total de lares & 1.376 .000 & 275.526 & 274.839 & 275.202 & 275.179 & 275.254 \\
$\begin{array}{c}\text { Renda média por lar * } \\
\text { mensal (US\$) }\end{array}$ & $\mathbf{1 . 9 4 2 , 9}$ & $\mathbf{3 9 0 , 4}$ & $\mathbf{8 6 5 , 2}$ & $\mathbf{1 . 3 3 8 , 9}$ & $\mathbf{2 . 0 6 2 , 5}$ & $\mathbf{5 . 0 5 7 , 3}$ \\
$\begin{array}{c}\text { Renda per capita por } \\
\text { lar*mensal (US\$) }\end{array}$ & 652,1 & 102,5 & 230,0 & 377,2 & 663,2 & $1.887,5$ \\
\hline
\end{tabular}

* Renda líquida com correção de valores não declarados e com ajuste por subdeclaração.

Valores em dólares, taxa de câmbio média de venda do BCCR, julho 2013: 504,40 colóns: 1 dólar.

Fonte: Produção do próprio autor com dados do Instituto Nacional de Estatística e Censo (2013). 
Seguidamente, utilizou-se a divisão por rendas dos lares, segundo os critérios da Fundação Promotora de Moradia (2011) ${ }^{15}$ :

- baixa renda, os lares com até quatro salários mínimos ${ }^{16}$ de ingressos (US\$ $1575,6)$;

- média renda, os lares de mais de quatro e até dez salários mínimos (US\$ $3939,0)$ e,

- alta renda, mais de dez salários mínimos de ingressos.

Com essa divisão, o I e II quintil da Enquete Nacional correspondem a baixa renda; no III quintil estariam misturados os últimos estratos da baixa renda e os primeiros da média renda; IV quintil seria média renda, e no $V$ quintil estariam média-alta e alta renda. A Tabela 4.5 mostra esta divisão mais claramente.

Tabela 4.5 - Divisão dos lares por renda

\begin{tabular}{|c|c|c|c|c|c|}
\hline $\begin{array}{l}\text { Quintil de renda per } \\
\text { capita }\end{array}$ & $\mathbf{I}$ & II & III & IV & V \\
\hline Alta renda & & & & & $\mathbf{X}$ \\
\hline Média-alta renda & & & & & $\mathbf{X}$ \\
\hline Média renda & & & & $\mathbf{X}$ & \\
\hline Média-baixa renda & & & $\mathbf{X}$ & & \\
\hline Baixa renda & $\mathbf{X}$ & $\mathbf{X}$ & $\mathbf{X}$ & & \\
\hline
\end{tabular}

\section{Oportunidades}

O.13 Mais de dois quintos da população está dentro dos lares com relevante poder aquisitivo.

Com essa segmentação das famílias, facilita-se realizar uma análise mais detalhada das necessidades existentes para os possíveis produtos que ofereceriam as empresas brasileiras.

\footnotetext{
15 Esta divisão foi feita devido a que, em um início, os subsídios de moradia pelo governo foram concedidos para famílias com rendas de até quatro salários mínimos, hoje em dia, há registro de famílias com renda de até seis salários mínimos.

${ }^{16}$ Tomando como base o salário mensal mínimo para um trabalhador no especializado da indústria da construção do segundo semestre do ano 2013: US\$393,90 (CR\$198.681).
} 


\section{b. Fatores de propriedade e do estado das moradias}

Segundo o Instituto Nacional de Estatística e Censo (2013), na Costa Rica há 1.348.036 moradias, da quais $71.6 \%$ são habitadas pelos proprietários e $\mathbf{1 9 , 0 \%}$ alugadas. Ou seja, 256.127 famílias no país não possuem moradia própria. A Figura 4.5 mostra a distribuição nos quintis do ingresso per capita, apresentando um comportamento uniforme, com exceção do primeiro quintil, que tem a menor percentagem de moradias alugadas (15,9\%).

Do estado das moradias do país: 57,6\% estão em bom estado, 33,0\% em estado regular e 9,4\% em mau estado, ou seja, 126.715 famílias precisariam, em curto prazo, mudar de moradia ou de uma reforma quase total de seu lar. A Figura 4.6 mostra a distribuição nos diferentes quintis, observando a relação clara entre os ingressos per capita do lar e as condições da moradia.

Figura 4.5 - Propriedade das moradias na Costa Rica ENAHO 2013

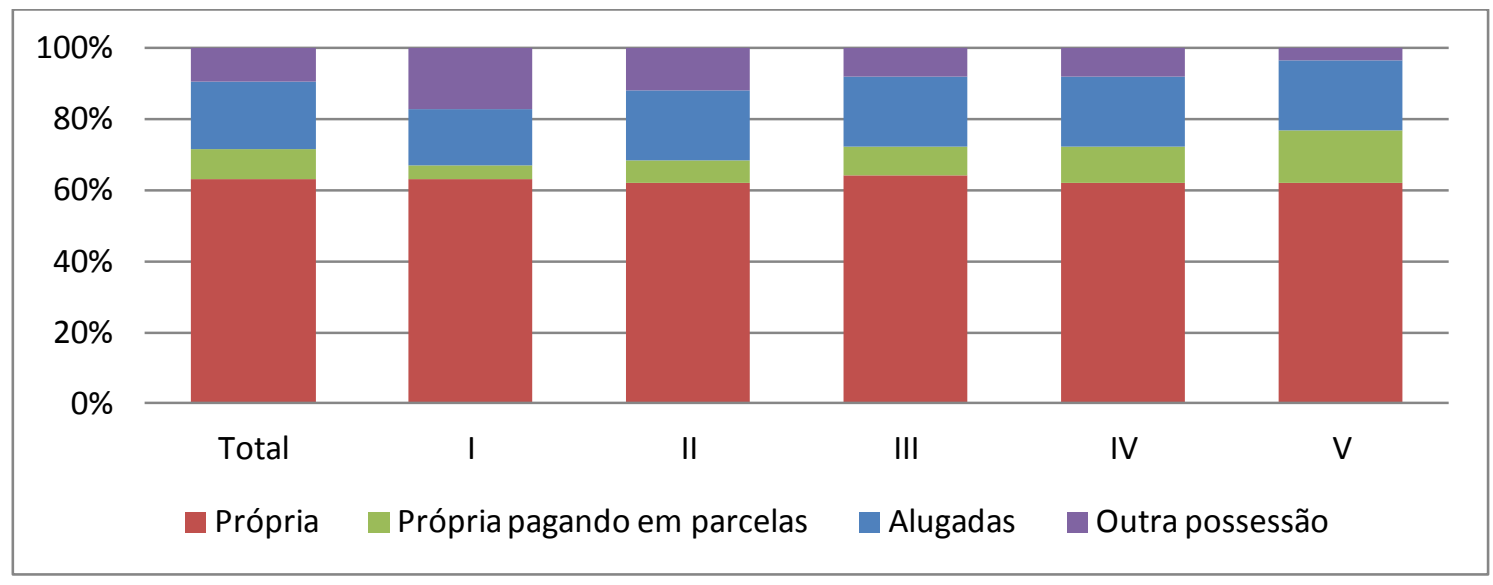

Fonte: Instituto Nacional de Estatística e Censo (2013, p. 20).

Figura 4.6 - Estado físico das moradias na Costa Rica ENAHO 2013

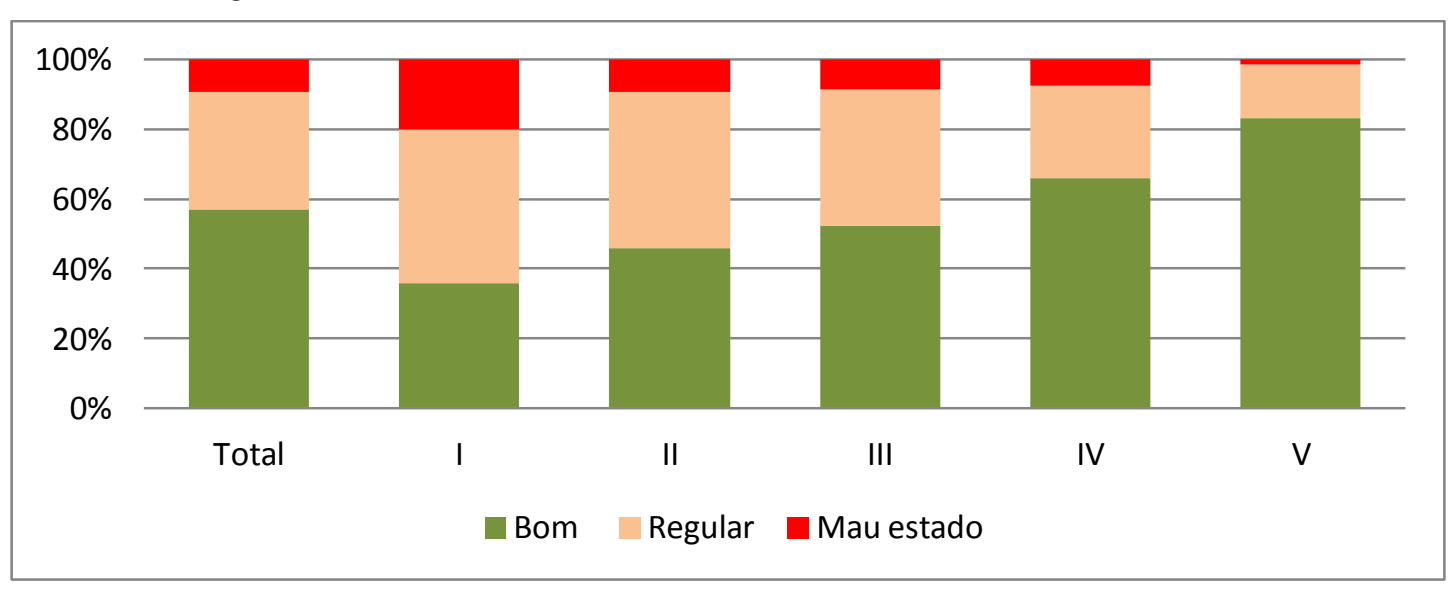

Fonte: Instituto Nacional de Estatística e Censo (2013, p. 22). 
Sob os supostos de aluguel e estado da moradia, soma-se um total de 383 mil famílias como potenciais clientes. Fazendo a divisão por segmentos de renda, seriam então: quase 252 mil moradias para baixa renda, 73 mil para média renda, e 57 mil para média-alta e alta renda.

\section{c. Déficit habitacional}

A Fundação Promotora de Moradia (2013) com a informação do ENAHO 2012 calculou o déficit habitacional da Costa Rica, para um total de 183.617 moradias sob o conceito de Déficit Habitacional Tradicional (DHT), e de 669.531 sob o conceito Déficit Habitacional Real (DHR) (o rodapé amplia estes conceitos ${ }^{17}$ ). Estes valores consideram a superlotação dos lares, de aproximadamente $4,5 \%$ do total das moradias com ocupação.

\section{Oportunidades}

O.14. A carência residencial do país (dependendo dos supostos para sua definição) está na faixa de 670 a 184 mil unidades. Estima-se uma demanda potencial de 383 mil unidades habitacionais considerando apenas as famílias que alugam e que moram em imóveis em mau estado.

${ }^{17}$ A metodologia para definir o déficit habitacional pelo Instituto Nacional de Estatística e Censo (INEC) são duas segundo a Fundação Promotora de Moradia (2012):

- DHT: A soma do Déficit Quantitativo ou Faltante Natural (FN): diferença entre a Moradia Individual Ocupada (MIO) e a quantidade de lares (famílias) não coletivos. Mais o Déficit Qualitativo Tradicional (DQT): que é a soma das moradias em mau estado e as moradias em que o estado é regular, ou com superlotação.

$$
\mathrm{DHT}=\mathrm{FN}+\mathrm{DQT}(\mathrm{M}+\mathrm{R}+\mathrm{Bs})(\mathbf{1})
$$

- DHR: A soma do FN mais o Déficit Qualitativo Real (DQR) que inclui: as moradias em mau estado, mais as de estado regular, as de bom a regular (ou seja, que tem algum ponto: teto, paredes ou chão em mal estado) e as moradias em bom estado superlotadas. Esta analise qualitativa é mais rigorosa ao incluir moradias que precisam de reformas, melhorias, ampliações ou que não se encontram no melhor estado.

$$
\mathrm{DHR}=\mathrm{FN}+\mathrm{DQR}(\mathrm{M}+\mathrm{R}+\mathrm{BR}+\mathrm{Bs}) \text { (2) }
$$




\section{d. Estoque residencial}

Para estimar o estoque residencial, utilizou-se o dado de desocupação das moradias na Costa Rica segundo o "X Censo Nacional da População e VI de Moradia" de 2011. Este censo levantou toda a informação de desocupação das moradias no país e seu motivo. A Tabela 4.6 mostra que $10,8 \%$ de todas as moradias no país estão desocupadas.

Tabela 4.6 - Desocupação das moradias na Costa Rica censo 2011

\begin{tabular}{|c|cc|}
\hline Tipo de Desocupação & \multicolumn{2}{|c|}{2011} \\
\hline $\begin{array}{c}\text { Desocupada em aluguel ou venda } \\
\text { Desocupada em construção } \\
\text { ou reforma }\end{array}$ & 51.426 & $34,9 \%$ \\
\hline $\begin{array}{c}\text { Desocupada temporariamente } \\
\text { (uso só em certas datas do ano) }\end{array}$ & 50.081 & $34,0 \%$ \\
\hline Outros motivos & 26.693 & $18,1 \%$ \\
\hline Moradia Individual Desocupada (MID) & 147.204 & $10,8 \%$ \\
\hline Moradia Individual Ocupada & 1.211 .964 & $89,2 \%$ \\
\hline (MIO) & 1.359 .168 & $100 \%$ \\
\hline \hline Total de Moradia Individual & & 1204 \\
\hline
\end{tabular}

Fonte: Fundação Promotora de Moradia (2012, p.33, tabela 2.7).

Do total de moradias desocupadas, o estoque residencial corresponderia às unidades desocupadas em aluguel ou venda (51.426 unidades), mais uma quantia das moradias desocupadas em construção ou reforma, arbitrando esse valor em umas 10.000 unidades (53\% do total de moradias nesta condição), o estoque residencial pode se estimar em 61 mil unidades.

Para ter uma noção da magnitude desse estoque residencial, o montante de unidades vagas poderia, hipoteticamente, resolver o problema de $16 \%$ das famílias que alugam e que moram em imóveis em mau estado.

\section{Oportunidades}

O.15. O estoque residencial do país abrange pouca parte da possível demanda habitacional. 


\section{e. Mudanças demográficas}

Para ter uma ideia da demanda potencial desse mercado, deve se considerar que no "X Censo Nacional da População 2011" foram registrados 4.301.712 habitantes, na ENAHO 2013 foram estimados 4.709.161, e espera-se que a população da Costa Rica aumente para 6,5 milhões de habitantes até a metade do século XXI, depois diminuiria para 6 milhões no fim do século, aumentando quase um $39 \%$ nos próximos 90 anos (MINISTÉRIO DA MORADIA E ASSENTAMENTOS HUMANOS, 2012a).

\section{Ameaça}

T.11. Tamanho do mercado costarriquenho, que é atualmente de 4,7 milhões de habitantes. Estima-se um crescimento de 6,5\% da população nos próximos quinze anos.

Segundo mostra-se na Tabela 4.7, desde o censo de 1984 a média de habitantes por lar vem caindo, isso como consequência de mudanças demográficas na Costa Rica, com a redução do número de famílias "típicas" costarriquenhas das décadas de 1960 e de 1980, que se caracterizavam por ter muitos membros. A Figura 4.7 oferece uma visão mais clara deste fenômeno.

Apesar da queda dos membros por família, o número de famílias não diminuiu, entre 1984 e 2000 estas crescerem a uma taxa média anual de 5,44\% e entre 2000 e 2011 de 2,64\%. Portanto, precisa-se cada vez de maior quantidade de unidades habitacionais para famílias com menor número de membros ${ }^{18}$.

Tabela 4.7 - Dados dos habitantes da Costa Rica segundo os Censos 1984, 2000 e 2011

\begin{tabular}{cccc}
\hline Ano & Habitantes & Lar & $\begin{array}{c}\text { Média } \\
\text { Habitantes/Lar }\end{array}$ \\
\hline $\mathbf{1 9 8 4}$ & 2.416 .809 & 513.431 & 4,7 \\
$\mathbf{2 0 0 0}$ & 3.810 .179 & 960.098 & 4,0 \\
$\mathbf{2 0 1 1}$ & 4.301 .712 & 1.238 .438 & 3,5 \\
\hline
\end{tabular}

Fonte: Fundação Promotora de Moradia (2012, p. 34).

\footnotetext{
${ }^{18}$ Deve-se esclarecer que no caso do planejamento de um empreendimento residencial, é necessário analisar mais detalhadamente as características das famílias da região. A exemplo das diferenças entre bairros, em cidades como Chirripo de Turrialba a média de pessoas por lar é de 5,1 , e no Carmen de São Jose de 2,5 (FUNDAÇÂO PROMOTORA DE MORADIA, 2013).
} 


\section{Oportunidades}

O.16. Nos últimos anos, é registrado um crescimento anual na quantidade de famílias costarriquenhas de 2,64\%, estas constituídas em sua maioria por 3 ou 4 membros.

Figura 4.7 - Frequência de quantidades de pessoas por lar

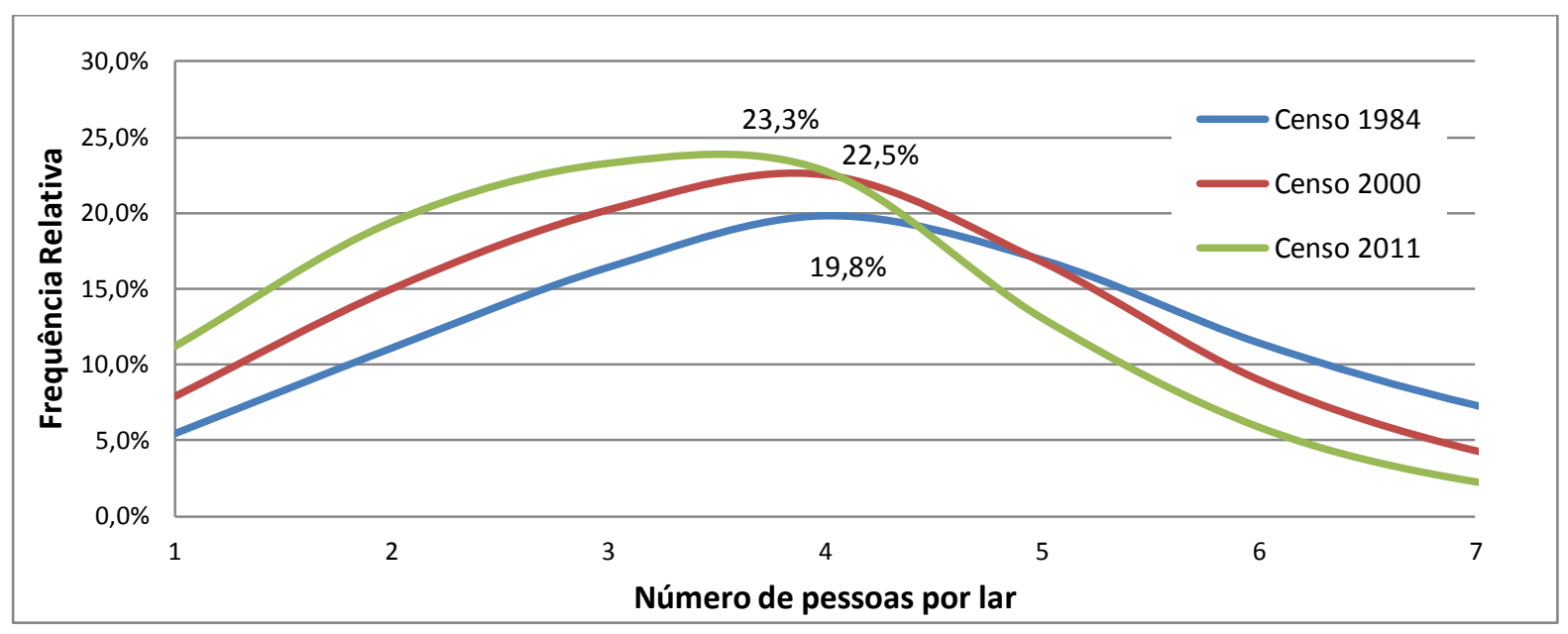

Fonte: Produção do próprio autor com dados da Fundação Promotora de Moradia (2012, p. 35, tabela 2.9).

\section{f. Tipologia construtiva}

O último elemento que foi analisado para caracterizar esse mercado, corresponde às tipologias de moradia preferida pela população costarriquenha ou cultura instalada. A Figura 4.8 mostra para a região urbana que casas contíguas e independentes têm maior peso, e unidades habitacionais em edifícios ainda representam uma pequena parte das residências da Costa Rica.

\section{Ameaça}

T.12. A cultura instalada no mercado residencial costarriquenho de morar em casas de um ou dois andares, pouca representatividade das unidades habitacionais em edifícios. 
Figura 4.8 - Percentagem de moradias ocupadas, período 2010-2013 ENAHO (só região urbana)

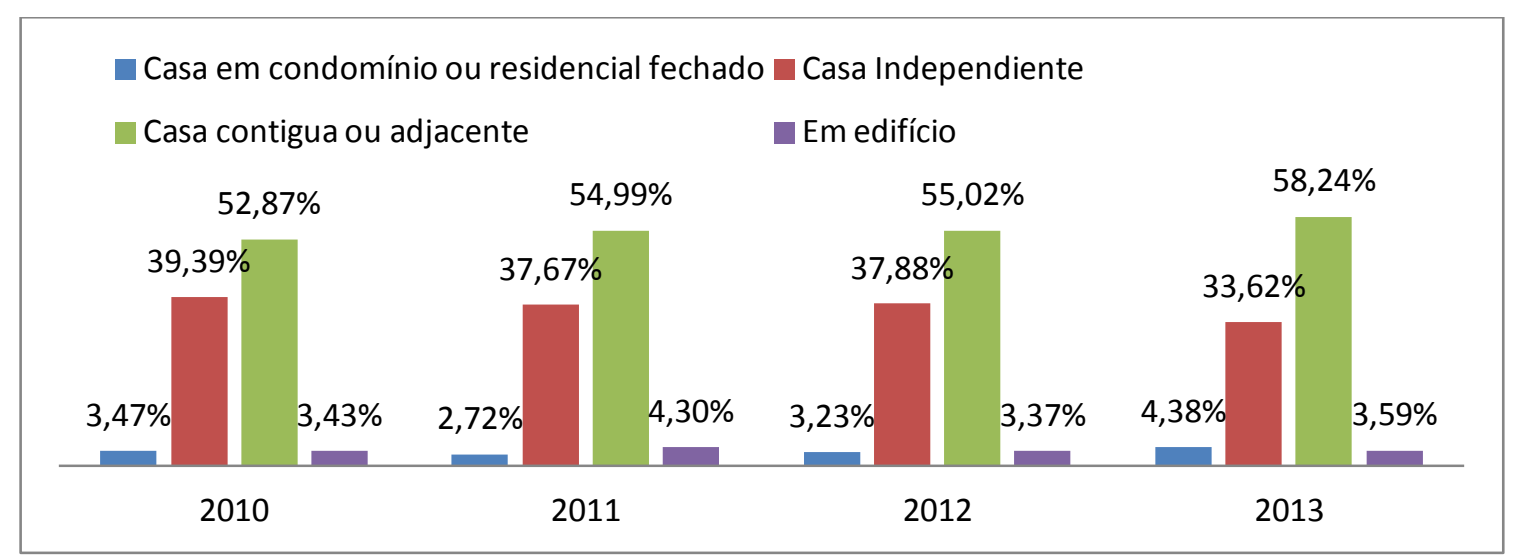

Fonte: Produção do próprio autor com dados do Instituto Nacional de Estatística e Censo (2014c).

\section{g. Estimativa da demanda potencial da GAM}

Pela importância que toma essa região, o Ministério de Moradia e Assentamentos Humanos (2012b) estimou que para o ano 2030 a GAM vai contar com 825.000 novos habitantes e serão necessárias entre 206.000 e 210.000 novas moradias. Isso sem contar aquelas que têm que se realocar por estarem em zonas de risco, e as que deveram ser reformadas ou reconstruídas por seu estado, somando assim um total de 250.000 novas moradias.

\section{Oportunidades}

O.17. A GAM vai precisar para 2030 de 250.000 novas moradias para seus 825.000 novos habitantes.

\subsubsection{Financiamento do setor residencial}

Devido à demanda intensiva de recursos da qual necessitam as atividades de real estate, equacionar os meios e fontes para alcançar os objetivos é uma das primeiras preocupações no ambiente estratégico da empresa (MONETTI, 2009). Portanto, a dependência da disponibilidade de linhas der crédito faz parte das atividades desse setor como elemento essencial para implantar empreendimentos residenciais, sendo imperativo destacar as ameaças e oportunidades derivadas do sistema de financiamento e das linhas de crédito para empresas e público na Costa Rica. 
Como generalidades, o sistema bancário da Costa Rica é regulado pela "Lei orgânica do Sistema Bancário Nacional" n 1644 de 26 de setembro de 1953, suas reformas e regulamentos. Fazem parte desse sistema o Banco Central da Costa Rica (BCCR), os bancos do estado, os bancos privados e outra entidade dentro do marco institucional dessa lei.

O Sistema Financeiro Nacional (SFN) conta com a vigilância e fiscalização da Superintendência Geral de Entidades Financeiras (SUGEF), esta zela pela estabilidade, solidez e funcionamento do sistema, salvaguardando o interesse da coletividade.

A respeito dos recursos para financiamento de projetos residenciais, o sistema financeiro da Costa Rica não tem nenhuma diretriz da quantidade de recursos que os bancos devem destinar para este fim. Ficando a discrição das Juntas Diretivas dos bancos regular as operações de crédito e estabelecer as condições gerais e limites das diferentes operações dentro das disposições legais (COSTA RICA, 1953).

As únicas restrições que os bancos têm para redirecionar seus recursos captados são:

- Toda instituição dentro do sistema financeiro nacional está obrigada a reter no BCCR em forma de depósito em conta corrente, uma reserva proporcional ao montante total de seus depósitos e captações, constituído como reserva mínima legal, sendo seu limite máximo quinze por cento (15\%) (COSTA RICA, 1995).

- Os bancos privados poderão captar recursos em conta corrente se mantiverem um saldo mínimo de empréstimos aos bancos do estado equivalente a dezessete por cento (17\%), uma vez que deduzida a reserva das captações totais no prazo de 30 dias ou menos, em moeda nacional e estrangeira (COSTA RICA, 1953).

- Cumprir com as obrigações em curto prazo. 
- Manter uma suficiência patrimonial ${ }^{19}$ igual ou superior a $10 \%$ (SUPERINTENDÊNCIA GERAL DE ENTIDADES FINANCEIRAS, 2001).

Como exemplo das diferentes políticas destinadas por cada banco para projetos residenciais, em 2012 a carteira de "construção, compra e reforma de imóveis" representou $16 \%{ }^{20}$ na banca estatal e $29,6 \%$ na banca privada da carteira total (FUNDAÇÃO PROMOTORA DE MORADIA, 2013).

\section{Ameaça}

T.13. O sistema financeiro da Costa Rica não tem nenhuma diretriz da quantidade de recursos que os bancos devem de destinar para este fim, cada banco estabelece suas políticas creditícias e os fundos destinados a cada produto ou linha de financiamento.

As atividades que por sua natureza têm uma lenta recuperação do recurso investido e requer vários anos de prazo para sua amortização, como no caso de empréstimos para moradia, os bancos poderão financiar essas operações pela captação de recursos via: conta corrente, poupança à vista, títulos de captação e outros tipos de recepção de depósitos, todas estas captações podem ser em moeda local e estrangeira $^{21}$ (COSTA RICA, 1953, Art. 80).

Outras maneiras que os bancos têm de financiar estas atividades podem ser com: recursos de seu capital e reservas, fundos do BCCR mediante operações creditícias e com a contratação de empréstimos no país ou no exterior (COSTA RICA, 1953, Art. 58).

\footnotetext{
${ }^{19}$ A suficiência patrimonial resulta da relação entre o patrimônio não redimível e os ativos totais ponderados segundo o grau de risco. Esse cálculo está definido pela SUGEF segundo os parâmetros estabelecidos.

${ }^{20}$ A menor porcentagem da banca estatal é devida a esta incluir bancos estatais que são exclusivos do setor agrícola. No caso do Banco da Costa Rica (BCR), do Banco Nacional da Costa Rica (BNCR) e do Banco Popular, todos da banca estatal, as porcentagens desta carteira, de seu total, foram de $29 \%, 35 \%$ e $33 \%$, respectivamente.

${ }^{21}$ A informação apresentada nesta seção foi corroborada com a consulta via e-mail com Helberth C. Cordero, oficial comercial do Banco da Costa Rica, sucursal Shopping Terramall, no dia 03 de abril de 2014.
} 


\section{Oportunidades}

O.18. Na Costa Rica o Sistema Financeiro Nacional é um sistema formal, estruturado e regulado.

\section{a. Linhas de crédito para empresas de real estate}

As empresas de real estate podem optar por um empréstimo ou pela estruturação de financiamentos para financiar seus empreendimentos na Costa Rica.

No caso de um empréstimo para empresa, as instituições financeiras, pela norma da Superintendência Geral de Entidades Financeiras (2004), têm como limite emprestar um montante máximo de $20 \%$ de seu patrimônio líquido, por empresa. Mas essa porcentagem pode ser menor, por exemplo, o Banco da Costa Rica (2014b) aponta que é o banco com o maior patrimônio do país, com US\$ 150 milhões, estabelece como política interna para créditos a empresas um máximo de $7 \%$ desse patrimônio (muito menor que 20\%, estabelecido como máximo), o que corresponde cerca de US\$10,5 milhões ou $R \$ 24,21$ milhões $^{22}$ que poderiam ser emprestados a uma única empresa.

A lei permite que uma empresa pudesse ter empréstimos com vários bancos ao mesmo tempo, aumentado assim o recurso captado para seus projetos.

As taxas de juros assinadas a essas operações vão depender do histórico de crédito do cliente, dos parâmetros de garantia e do risco comercial da empresa. Para empréstimos em dólares a referência da taxa de juros é a Taxa Prime Rate (TPR) e em moeda local a referência é a Taxa Passiva Básica (TBP) ${ }^{23}$ (BANCO DA COSTA RICA, 2014a).

\footnotetext{
${ }^{22}$ Taxa de câmbio média, valor de compra de 11/05/2014 até 11/11/2014, segundo o BCB: R $\$ 2,306$ por dólar.

${ }^{23}$ A TBP é a média ponderada das taxas de juros de captação brutas em colóns, negociadas pelos intermediários financeiros residentes no país, e as taxas de juros dos instrumentos de captação do BCCR e o Ministério da Fazenda, negociadas tanto no mercado primário como no secundário, todas elas em prazos de entre 150 e 210 dias (PROGRAMA ESTADO DA NAÇÃO, 2012).

A TBP é a referencia para as demais as taxas de juros em moeda local na economia da Costa Rica, equivalente à taxa SELIC (Sistema Especial de Liquidação e de Custódia) no Brasil.
} 


\section{Ameaça}

T.14. As regulações na Costa Rica permitem que as instituições financeiras emprestem no máximo $20 \%$ de seu patrimônio líquido por empresa, mas as políticas internas de cada instituição podem ser mais restritas, limitando o montante máximo do empréstimo.

O desembolso de recursos e demais detalhes desses empréstimos são característicos de qualquer transação bancária, sempre com um estrito controle do investimento por parte das entidades financeiras. Entre estes podem ser citados:

- Análise da empresa incorporadora

- Análise do risco imobiliário do projeto

- Capacidade técnica e financeira para realizar o projeto

- Viabilidade dos fluxos de caixa do projeto

- Sucesso comercial do projeto (FERNÁNDEZ, 2011)

No caso da estruturação de financiamentos, as empresas podem, por meio de um banco gestor, realizar securitização da dívida para a emissão de papéis e a negociação no mercado de capitais.

Também conta-se com a opção de Fundos de Investimento Imobiliário (FII) para financiar projetos residenciais, porém são pouco usados. Em outubro de 2013, registram-se três fundos, dois deles sob o seguinte esquema: são emitidos os títulos de investimento para financiar o projeto, quando este é vendido em sua totalidade, o fundo é liquidado e os investidores recebem seu capital mais os rendimentos. Auferiu-se nos passados fundos liquidados uma taxa interna de retorno entre $12 \%$ a 14\% nominal (DELGADO, 2013b).

O terceiro fundo foi estruturado para um projeto com a modalidade "leasing", as unidades residenciais do projeto são alugadas com opção de compra para os moradores depois de cinco anos. Os investidores recebem uma renda mensal no período de locação do produto deste, e no final da etapa recebem o montante correspondente à venda dos imóveis (RODRíGUEZ, 2013a). 


\section{Oportunidades}

O.19. Diversas alternativas para que as empresas de real estate financiem seus empreendimentos: empréstimos a empresa e estruturação de financiamentos.

O engenheiro Wagner Calderon ${ }^{24}$ profissional em desenvolvimento de projetos imobiliários, de sua experiência, enfatiza que os problemas dos financiamentos para empresas de real estate no sistema bancário costarriquenho são: a quantidade de requisitos requeridos pelos bancos para ser candidato a um crédito, a complexidade e a demora para a obtenção do alvará de construção. Esses dois processos fazem com que os bancos redirecionem os recursos para outros tipos de projetos, quando a documentação e o alvará de construção estão prontos.

\section{Ameaça}

T.15. A quantidade de requisitos solicitados pelos bancos para ser candidato a um financiamento, a complexidade e a demora para a obtenção do alvará de construção fazem com que que os bancos redirecionem seus recursos para outros tipos de projetos.

\section{b. Linhas de crédito para público ou pessoas físicas}

A disponibilidade para linhas de financiamento para pessoas físicas pode ser dada por meio de um banco público ou privado, mutuais de poupança, pelo departamento do Banco Hipotecário da Moradia (BANHVI) da Costa Rica, pelo Instituto Nacional de Moradia e Urbanismo (INVU) em seus programas de poupança e empréstimos, ainda por citar os mais importantes.

Segundo o "Relatório sobre os programas de crédito direcionados a moradia" do Ministério da Moradia e Assentamentos Humanos (2013a), o mercado financeiro costarriquenho oferece uma ampla gama de produtos creditícios para moradia, derivados de um programa matriz denominado "Crédito Moradia", tendo as seguintes variações:

\footnotetext{
${ }^{24}$ Entrevista feita por email no dia 02 de abril de 2014.
} 
- O plano de investimento: compra, construção, reforma, melhoria, expansão, cancelamento de hipotecas e outros.

- A taxa de juros: fixa, variáveis e escalonada (predominantes). Em moeda local e dólares (ver Tabela 4.8), com prestações "Price" (nivelada).

- A finalidade: comercial (tradicional) e social (que se complementa com subsídio governamental).

- A tipologia: em série, vertical, condomínio, turística.

- Número de moradias: primeira, segunda ou mais (MINISTÉRIO DA MORADIA E ASSENTAMENTOS HUMANOS, 2013a).

Tabela 4.8 - Exemplos de vários planos de financiamento de moradia

\begin{tabular}{|c|c|c|c|c|}
\hline Banco & $\begin{array}{c}\text { Tipo de } \\
\text { banco }\end{array}$ & $\begin{array}{c}\text { Moeda do } \\
\text { financiamento }\end{array}$ & $\begin{array}{l}\text { Tipo de taxa } \\
\text { de juros }\end{array}$ & Característica \\
\hline $\begin{array}{l}\text { BAC- } \\
\text { SJ }\end{array}$ & Privado & Local & Variável & $\begin{array}{l}\text { Fixa primeiro ano de } 9 \% \\
\text { Fixa segundo ano de } 10 \% \\
\text { A partir do } 3^{\circ} \text { ano } \mathrm{TBP}+4,75 \% \\
\text { sem chão }\end{array}$ \\
\hline $\begin{array}{l}\text { BAC- } \\
\text { SJ }\end{array}$ & Privado & Dólar & Variável & $\begin{array}{l}3 \text { anos de Libor } 3+7,25 \text { pp } \\
\text { A partir do } 4^{\circ} \text { ano de Libor } 3+8,25 p p \text {, } \\
\text { sem taxa mínima }\end{array}$ \\
\hline BCR & Estatal & Local & Escalonada & $\begin{array}{l}\text { 1 ano: TBP }+1,5 \% \\
2^{\circ} \text { ano: TBP }+2,5 \% \\
3^{\circ} \text { ano: TBP }+3,5 \% \\
\text { A partir do } 4^{\circ} \text { ano: } \text { TBP }+4,0 \%\end{array}$ \\
\hline BCR & Estatal & Dólar & Escalonada & $\begin{array}{l}1 \% \text { ano: Prime }+3,75 \% \\
2^{\circ} \text { ano: Prime }+4,25 \% \\
\text { A partir de } 3^{\circ} \text { ano: Prime }+5,25 \%\end{array}$ \\
\hline
\end{tabular}

(2013a) e BAC San José (2014).

Entre as condições mais comuns estabelecias pelas entidades para empréstimos de moradia está:

- Relação prestação-renda: entre $30 \%$ e $65 \%$, de acordo com a capacidade de pagamento.

- Garantia: hipoteca e fiança (poucos casos).

- Prazo: entre 7 e 30 anos como máximo.

- Montante mínimo a financiar a partir de US\$1 mil e um máximo, dependendo da capacidade de pagamento e garantias.

- Percentagem de financiamento: entre $70 \%$ e 100\% (dependendo de garantias adicionais) da avaliação. 
- Comissões ou taxas ${ }^{25}$ : entre $0 \%$ e $3 \%$.

- Seguros: as mais frequentes são as de vida, incêndio, saldo devedor e desemprego.

- A referência para a taxa de juros em moeda local é a TBP. Para o dólar a taxa de referência é a Libor ou a Prime (ver Tabela 4.8) (MINISTÉRIO DA MORADIA E ASSENTAMENTOS HUMANOS, 2013a).

\section{Oportunidades}

O.20. O sistema bancário tem diversas alternativas para o financiamento de moradia própria.

Em seguida, mostra-se a comparação entre a taxa de referência da economia brasileira (Sistema Especial de Liquidação e de Custódia, SELIC) e costarriquenha (TBP), assim como o comportamento das taxas de juros para o financiamento imobiliário nos últimos anos de ambos os países (ver Figura 4.9 e Figura 4.10).

Figura 4.9 - Média anual das taxas de referência para juros no Brasil e na Costa Rica no período de 2002-2013

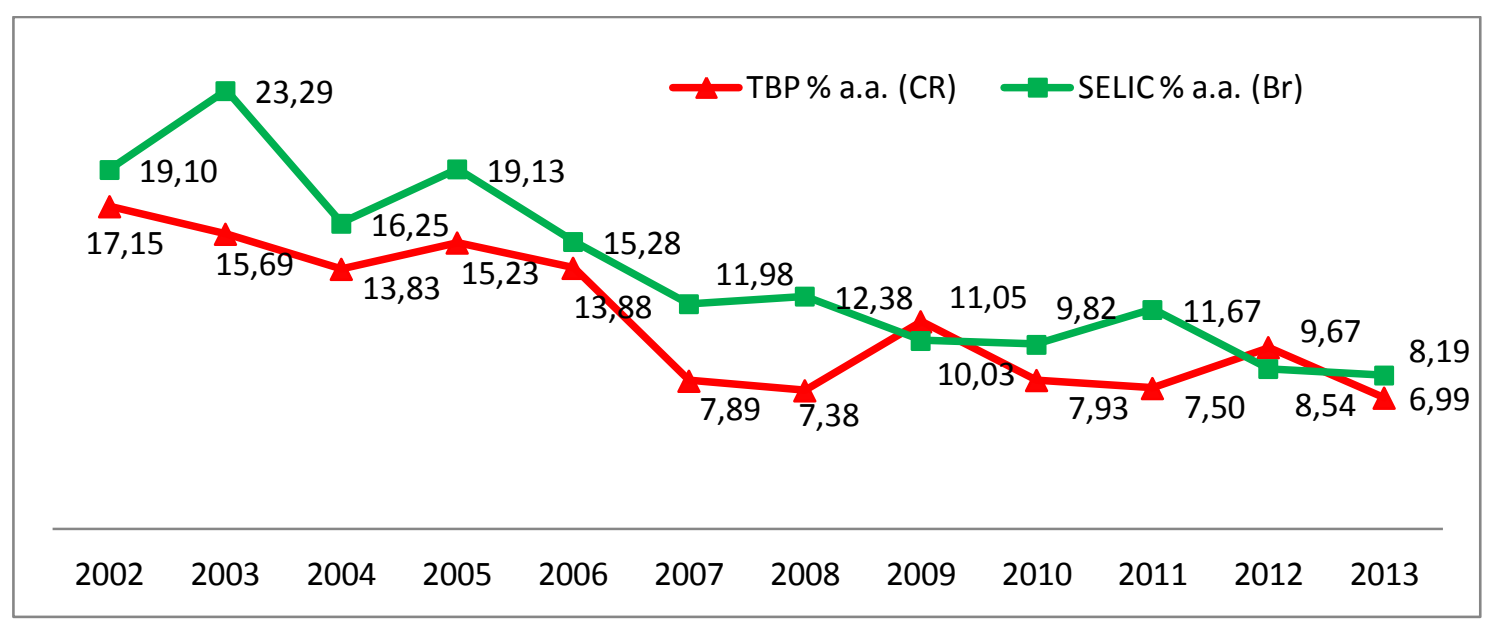

*Média com informação diária

Fonte: Produção do próprio autor com os dados do Banco Central de Costa Rica (2014) e Banco Central do Brasil (2014).

\footnotetext{
${ }^{25}$ Este item corresponde às tarifas ou despesas que os bancos cobram sobre o montante emprestado pela preparação da documentação e demais gastos administrativos incorridos na transação.
} 
Figura 4.10 - Taxa de juros para financiamento imobiliário Costa Rica e Brasil

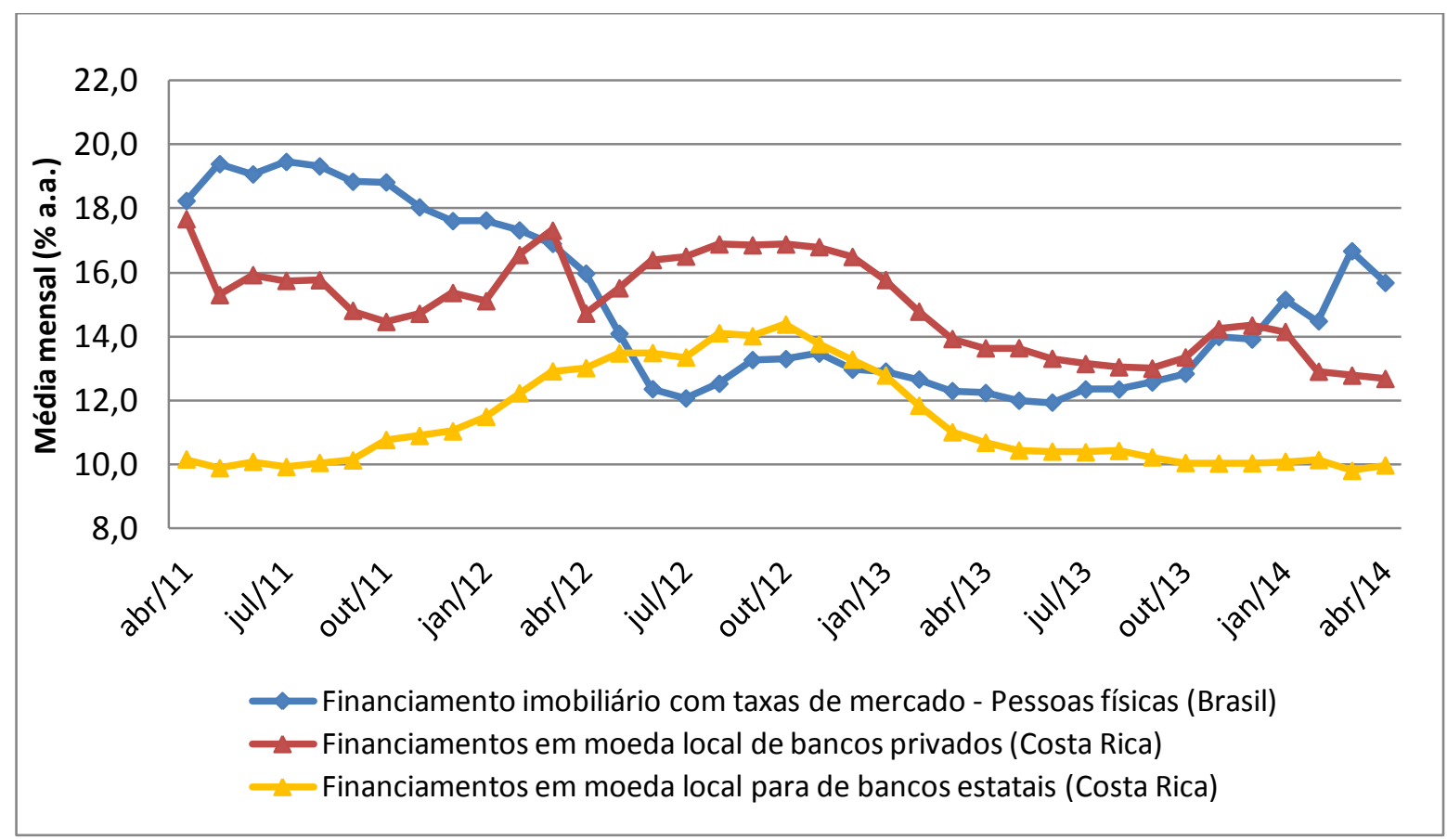

Fonte: Produção do próprio autor com dados do Banco Central da Costa Rica (2014) e Banco Central do Brasil (2014).

Historicamente, na Costa Rica os bancos estatais apresentam as taxas de juros mais baixas do mercado, mas os bancos privados contam com planos atrativos estruturados para seus clientes, incluindo vários benefícios.

\section{Oportunidades}

0.21. As taxas de juros para moradia, momentaneamente, apresentam valores baixos, segundo os registros históricos.

Analisando a saúde do sistema, uma maior segurança nos controles e análises na hora de assinar os créditos é feita pelos bancos privados, apresentando uma carteira atrasada e em cobrança judicial de 5,75\% contra 9,76\% da banca estatal e 20,05\% das mutuais de poupança (MINISTÉRIO DA MORADIA E ASSENTAMENTOS HUMANOS, 2013a).

Segundo o relatório do MINVAH, os problemas que desmotivam a aquisição de um empréstimo para moradia são o número de requisitos, mais de 15 requisitos em vários casos; a espera para a aprovação, entre 3 e 6 semanas em média, e altos 
custos de formalização. Somado a isso, as taxas mínimas de juros e os sistemas escalonados não favorecem os devedores quando TBP está em baixa.

\section{Ameaça}

T.16. A dinâmica dos sistemas de financiamento pode desmotivar a aquisição de um empréstimo para moradia a clientes de projetos residenciais pelo número de requisitos, tempo de aprovação, custos de formalização e estruturação das taxas de juros.

Outro problema que se apresenta para a aquisição moradia é o fato de as famílias não contarem com uma poupança acumulada o suficiente para a entrada do imóvel, que é em torno de $30 \%$ a $20 \%$ do valor total (FUNDAÇÃO PROMOTORA DE MORADIA, 2013; MINISTÉRIO DA MORADIA E ASSENTAMENTOS HUMANOS, 2013c).

\section{Ameaça}

T.17. Pouca poupança acumulada ou carência de uma cultura de poupança pelas famílias costarriquenhas.

Para diminuir este problema da poupança acumulada das famílias, especialmente nos estratos médios, o governo tem implementado certas políticas, como o "Bônus Diferido", que se aplica como uma ajuda na entrada da compra do imóvel e na amortização das quotas do empréstimo de moradia. Também a Lei de Operações Garantidas, na qual o BANHVI, por suas entidades autorizadas, responderia por $15 \%$ da entrada do imóvel.

\section{Oportunidades}

O.22. Estão em aplicação várias políticas que tentam incentivar o acesso de moradia à classe média, ajudando especialmente na entrada da compra do imóvel com algum tipo de subsídio. 


\subsubsection{Nível de absorção de mercado}

O nível de absorção do mercado costarriquenho vai ser balizado com a análise do volume de moradias que obtiveram "o alvará de construção" ${ }^{26}$ nas prefeituras locais e o recurso disponibilizado pelo SFN para o setor moradia, dos últimos anos.

A Figura 4.11 mostra como o número de moradias com o alvará de construção (linha vermelha) acompanha o recurso disponibilizado para moradia (colunas). Ambos indicadores diretamente relacionados ${ }^{27}$ e influenciados pelos acontecimentos na economia nacional e internacional. Um exemplo disso é a queda de 2008 para 2009 das unidades residenciais e o volume de recurso colocado em moradia, devido à Crise Econômica Mundial de 2008.

Figura 4.11 - Colocação anual do total de créditos para moradia no SFN em moeda local e número de moradias com alvará de construção

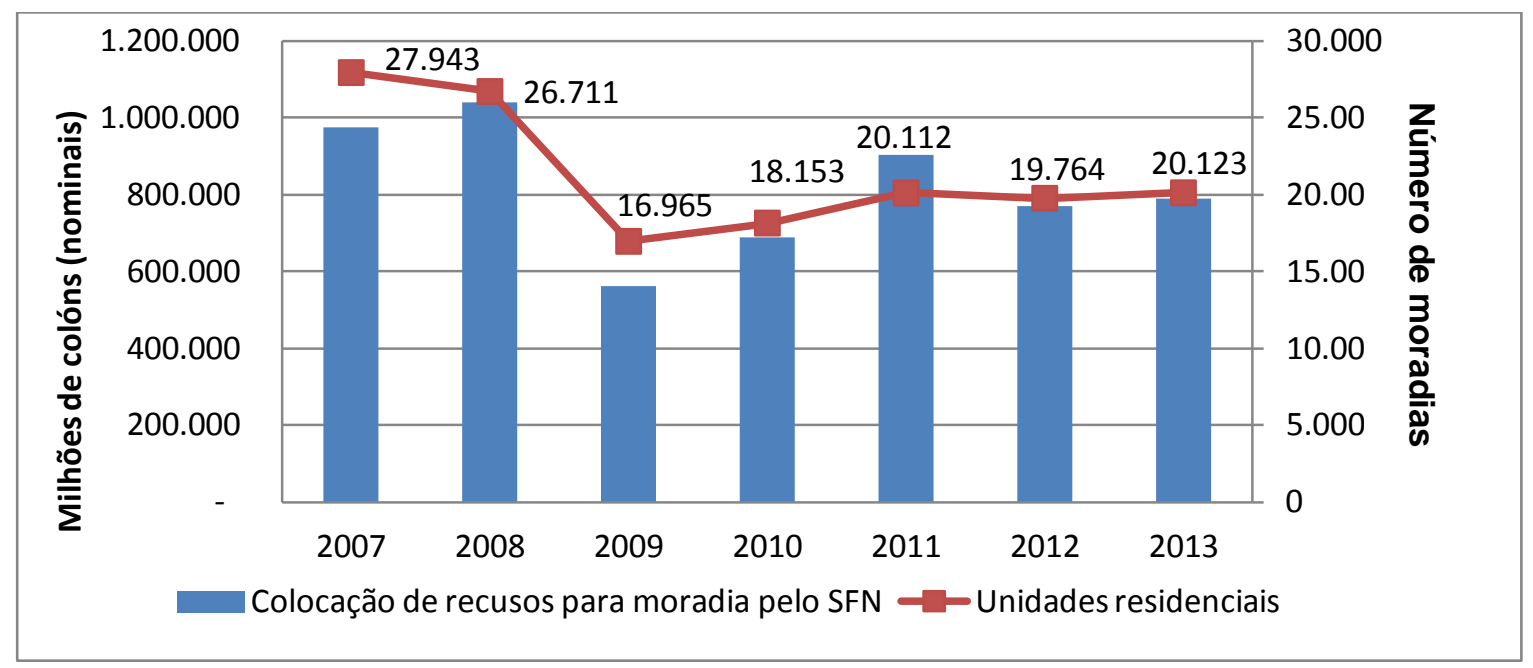

Fonte: Produção do próprio autor com os dados do Banco Central da Costa Rica (2014) e Instituto Nacional de Estatística e Censo (2014b).

\footnotetext{
${ }^{26}$ O alvará de construção (el permiso de construcción, em espanhol) é indispensável para toda construção na Costa Rica e é fornecido pela prefeitura local, sendo o último processo antes do início da construção. Mas isso não quer dizer que a construção tem sido executada ou finalizada. A informação se refere a construções novas e inclui moradias e apartamentos como unidades habitacionais.

${ }^{27}$ Esta relação entre variáveis é muito forte, pois como requisito para um crédito de moradia, os bancos pedem o "alvará de construção".
} 


\section{Ameaça}

T.18. Os bancos têm um comportamento mais cauteloso depois da crise de 2008, com a diminuição de recursos colocados para moradia, acompanhando os resultados da economia local.

Conclui-se da Figura 4.11 que o nível de absorção do mercado residencial costarriquenho é de aproximadamente 20.000 unidades residenciais por ano. O autor considera que este número vai manter-se assim pelos menos os próximos quatro anos (mandato do novo governo eleito), até que não seja vislumbrado um melhor ambiente econômico no país e/ou sejam implementados programas mais agressivos para liberação de crédito para as classes médias.

Para ter uma ideia da distribuição destas 20.000 unidades, a Tabela 4.9 mostra o número de obras em relação aos metros quadrados de construção referidos no alvará de construção em 2013.

Tabela 4.9 - Número de moradia para 2013 em relação aos metros quadrados de construção

\begin{tabular}{lc}
\hline \multicolumn{1}{c}{$\begin{array}{c}\text { Metros quadrados de } \\
\text { construção }\end{array}$} & $\begin{array}{c}\text { Número de } \\
\text { moradias }\end{array}$ \\
\hline Menos de $\mathbf{4 0}$ & 496 \\
De $\mathbf{4 0}$ a menos de $\mathbf{7 0}$ & 11.279 \\
De 70 a menos de 100 & 2.686 \\
De 100 a menos de 150 & 2.710 \\
De 150 a menos de 200 & 1.483 \\
De 200 e mais & 1.469 \\
Total & $\mathbf{2 0 . 1 2 3}$ \\
\hline
\end{tabular}

Fonte: Produção do próprio autor com dados do Instituto Nacional de Estatística e Censo (2014a).

\subsubsection{Ação da concorrência e oferta competitiva}

O último elemento a ser analisado do mercado residencial costarriquenho é a oferta competitiva em conjunto com a ação da concorrência. Esta última consiste na análise histórica do comportamento das empresas do setor sob uma determinada configuração de variáveis do ambiente externo. 
Alencar (1993) realça como imperfeições desta análise:

- A incerteza de os concorrentes tomarem as mesmas atitudes diante das mesmas situações anteriores;

- A repetição do conjunto de variáveis no ambiente externo é bastante improvável;

- A concorrência amadora que reage de acordo com as oportunidades do mercado.

Recomenda-se, em planos de ação empresarial, que seja analisada a ação da concorrência de maneira separada para cada segmento do mercado.

\section{a. Antecedentes}

Nos anos anteriores, as empresas de real estate residencial da Costa Rica tiveram que enfrentar uma desaceleração de suas atividades, em geral, todo o setor de construção foi impactado pelo comportamento da economia local depois da crise mundial de 2008. Como ilustra a Figura 4.12, apesar da economia de 2010 e de 2011 apresentarem uma recuperação, o setor de construção se manteve em números negativos até final de 2011.

Figura 4.12 - Variação percentual da economia e do setor de construção no período 2007-2014

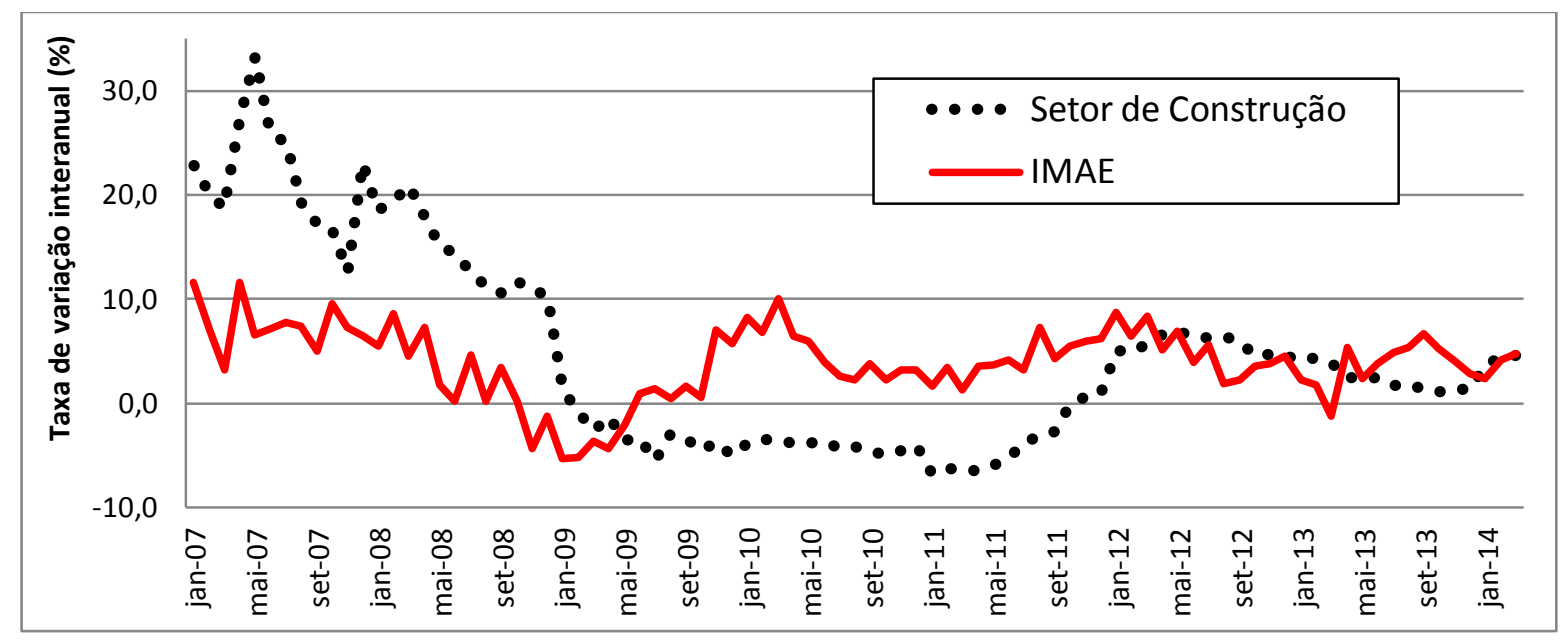

(*) Ano $1991=100$

Fonte: Produção do próprio autor com dados do Banco Central da Costa Rica (2014) 
Essa desaceleração do setor de real estate foi também evidente na diminuição de metros quadrados em permissões de construção aprovadas nas prefeituras (ver Figura 4.13), mostrando só uma leve recuperação em 2011.

Figura 4.13 - Metros quadrados aprovados em permissões de construção

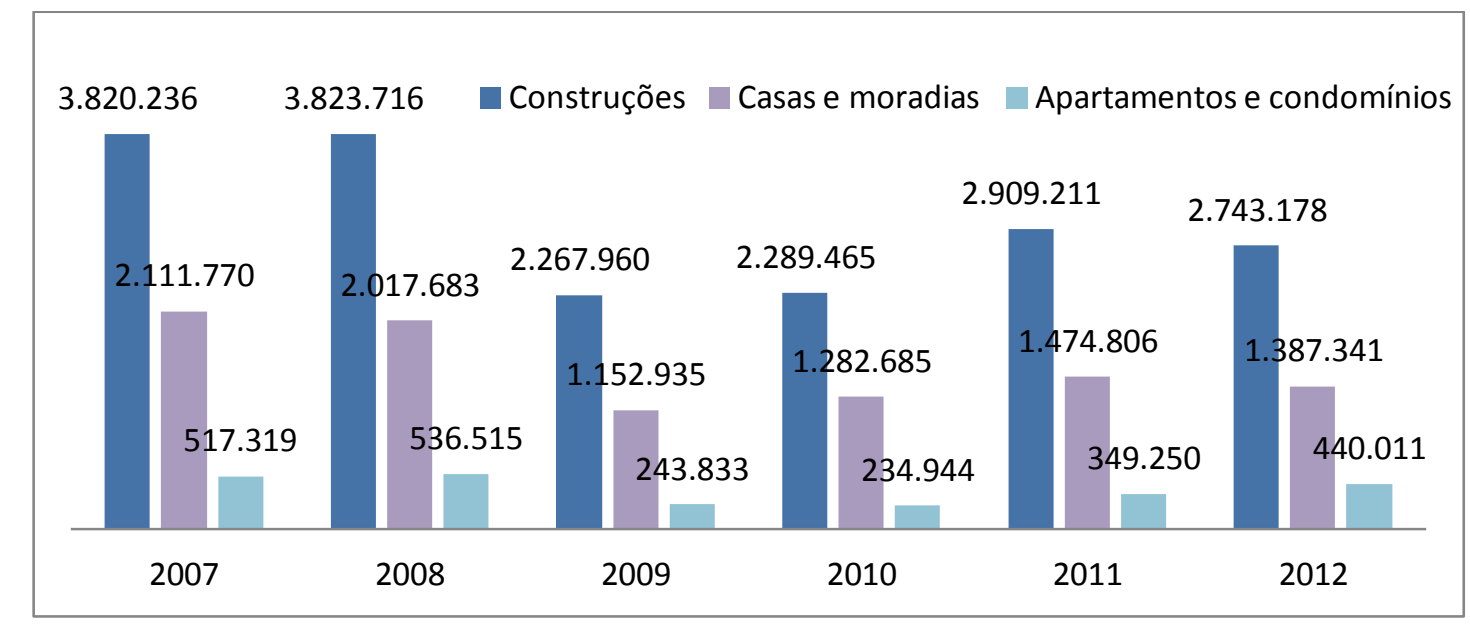

Fonte: Produção do próprio autor com dados do Instituto Nacional de Estatística e Censo (2014c) (ainda sem dados de 2013).

Como dado importante a ressaltar da figura anterior, embora a construção de casas e construções em geral não recuperem os valores anteriores à crise, os metros quadrados de apartamentos e condomínios seguem em aumento a cada ano, tomando grande importância entre os produtos comercializados nos últimos anos.

\section{Oportunidades}

O.23. Mudanças nas tendências de moradia nos últimos anos, com importante participação no lançamento de apartamentos e condomínios.

Esse aumento nessa tipologia construtiva se deve em parte às políticas de repovoamento e otimização dos solos urbanos com a verticalização das cidades, especialmente na GAM, como foi mencionado anteriormente. Para meados do ano de 2012, a prefeitura de São José registrada mais de 215 mil metros quadrados nessa tipologia, por um total de US\$111 milhões (CAMACHO, 2012). 
Hoje em dia, a tendência dos grandes investidores e empresas tem dado foco em projetos mais ambiciosos, de uso misto com unidades residenciais, hotéis, comércio e escritórios, como se apresenta na Tabela 4.10.

Tabela 4.10 - Projetos de uso misto de relevância na Costa Rica

\begin{tabular}{|c|c|c|c|c|c|}
\hline Projeto & Belén Center & Bambú & Punta Fina & Vive Sabanilla & Distrito 4 \\
\hline Componentes & $\begin{array}{c}\text { Residencial, } \\
\text { comércio e hotel }\end{array}$ & $\begin{array}{l}\text { Residencial, } \\
\text { escritórios e } \\
\text { comércio }\end{array}$ & $\begin{array}{l}\text { Residencial e } \\
\text { comércio }\end{array}$ & $\begin{array}{l}\text { Residencial, } \\
\text { escritórios e } \\
\text { comércio }\end{array}$ & $\begin{array}{l}\text { Residencial, } \\
\text { escritórios e } \\
\text { comércio }\end{array}$ \\
\hline $\begin{array}{c}\text { Características } \\
\text { residenciais }\end{array}$ & $\begin{array}{l}4 \text { prédios de } 13 \\
\text { apartamentos }\end{array}$ & $\begin{array}{c}5 \text { prédios de } 12 \\
\text { andares, quase } \\
500 \\
\text { apartamentos }\end{array}$ & $\begin{array}{c}1 \text { torre de } 11 \\
\text { andares, } 119 \\
\text { unidades (1 } \\
\text { fase) }\end{array}$ & $\begin{array}{c}3 \text { torres de } 5 \\
\text { andares } \\
\text { (114 unidades) }\end{array}$ & $\begin{array}{c}220 \\
\text { apartamentos }\end{array}$ \\
\hline Locação & Belén, Heredia & $\begin{array}{l}\text { San Sebastián, } \\
\text { San José }\end{array}$ & Ulloa, Heredia & $\begin{array}{c}\text { San Pedro, San } \\
\text { José }\end{array}$ & Escazú, San José \\
\hline Investimento & $\$ 35$ milhões & N.D. & $\$ 150$ milhões & $\$ 5$ milhões (1f) & \$25 milhões \\
\hline Construção & $39.000 \mathrm{~m}^{2}$ & $60.000 \mathrm{~m}^{2}$ & $175.000 \mathrm{~m}^{2}$ & $12.614 \mathrm{~m}^{2}$ & $67.000 \mathrm{~m}^{2}$ \\
\hline Estado atual & Lançamento & Lançamento & Em tramites & Construção & $\begin{array}{c}\text { Entrega das } \\
\text { primeiras fases }\end{array}$ \\
\hline Desenvolvedor & $\begin{array}{c}\text { Guillermo von } \\
\text { Breymann }\end{array}$ & RC Inmobiliaria & $\begin{array}{c}\text { Grupo } \\
\text { Inmobiliario del } \\
\text { Parque }\end{array}$ & $\begin{array}{l}\text { Fabián } \\
\text { Villamichel }\end{array}$ & GTU desarrollos \\
\hline
\end{tabular}

Fonte: Produção do próprio autor com dados de Brenes (2014) e Delgado (2013a).

\section{Ameaça}

T.19. A concorrência local é capaz de suprir a demanda comercial e residencial do mercado nacional.

\section{b. Oferta competitiva da GAM}

Embora o trabalho pretenda abranger todo o mercado residencial da Costa Rica, devido ao peso que tem o mercado residencial da GAM sobre o mercado nacional, torna-se relevante o estudo de sua oferta competitiva para aquelas empresas internacionais interessadas neste mercado (como o caso de CONCASA, empresa venezuelana com atuação no mercado costarriquenho).

Projetos residenciais fora da GAM têm outros tipos de características, mais focado ao setor turístico com clientes estrangeiros. 
Nessa parte do trabalho, utilizou-se o "Relatório Nacional de Moradia: Situação de Moradia e Desenvolvimento Urbano na Costa Rica 2012" da Fundação Promotora de Moradia (2013), que levantou dados de revistas, eventos, férias e websites de real estate residencial. Como eles mesmos realçam em seu trabalho, não é um censo, nem uma mostra do universo de projetos residenciais, mas dá uma aproximação à realidade da oferta de moradia na GAM.

A Fundação Promotora de Moradia (2013) dividiu os produtos de moradia ofertados em três segmentos: menores a US\$100 mil, entre US\$100 e US\$200 mil e maiores a US\$ 200 mil. Assim, foi ligada a renda média das famílias a um montante que seria emprestado ${ }^{28}$ pelo SFN para compra do imóvel.

Os produtos menores que US\$100 mil seriam dirigidos às famílias dos três primeiros quintis: baixa e média-baixa renda. Os produtos entre US\$ 100 e US\$ 200 mil para o IV quintil e parte do V quintil: média e média-alta renda, e os produtos acima dos US\$200 mil para alta renda.

A Tabela 4.11 e a Figura 4.14 apresentam que a maioria das soluções habitacionais estão entre os US\$100 mil e US\$200 mil, com uma área média de $123 \mathrm{~m}^{2}$ e de 2 a 3 apartamentos. Embora os produtos desta faixa estejam disponíveis para classe média e média-alta, a realidade é que a maioria das unidades nessa faixa estão acima dos US\$150 mil, sendo público alvo os de média-alta e alta renda.

Tabela 4.11 - Ação da concorrência na GAM

\begin{tabular}{|c|c|c|c|c|c|c|}
\hline \multirow{2}{*}{$\begin{array}{c}\text { Preço aprox. da } \\
\text { unidade habitacional } \\
\text { (Mil) }\end{array}$} & \multicolumn{2}{|c|}{ Projetos } & \multicolumn{2}{|c|}{$\begin{array}{c}\text { Unidades } \\
\text { habitacionais }\end{array}$} & \multirow{2}{*}{$\begin{array}{c}\begin{array}{c}\text { Média de } \\
\text { soluções por } \\
\text { projeto }\end{array} \\
143 \\
\end{array}$} & \multirow{2}{*}{$\begin{array}{r}\begin{array}{r}\text { Área média } \\
\text { da unid. }\left(\mathrm{m}^{2}\right)\end{array} \\
115\end{array}$} \\
\hline & 8 & $10,1 \%$ & 1140 & $14,8 \%$ & & \\
\hline entre $\$ 100$ e $\$ 200$ & 49 & $62,0 \%$ & 4945 & $64,0 \%$ & 101 & 123 \\
\hline$>$ de $\$ 200$ & 11 & $13,9 \%$ & 833 & $10,8 \%$ & 76 & 206 \\
\hline N/D & 11 & $13,9 \%$ & 806 & $10,4 \%$ & 73 & 152 \\
\hline Total & 79 & $100,0 \%$ & 7724 & $100,0 \%$ & 98 & \\
\hline
\end{tabular}

Fonte: Produção do próprio autor com dados da Fundação Promotora de Moradia (2013).

\footnotetext{
${ }^{28} \mathrm{~A}$ Fundação Promotora de Moradia (2013) com vários supostos de: taxa de juros, prazo do empréstimo, renda familiar e parcela inicial, calcula para cada segmento de renda o valor máximo do imóvel que teria acesso nos bancos da Costa Rica. Recomenda-se revisar este documento para maior informação dos supostos considerados.
} 
Figura 4.14 - Densidade de projetos por número de dormitórios

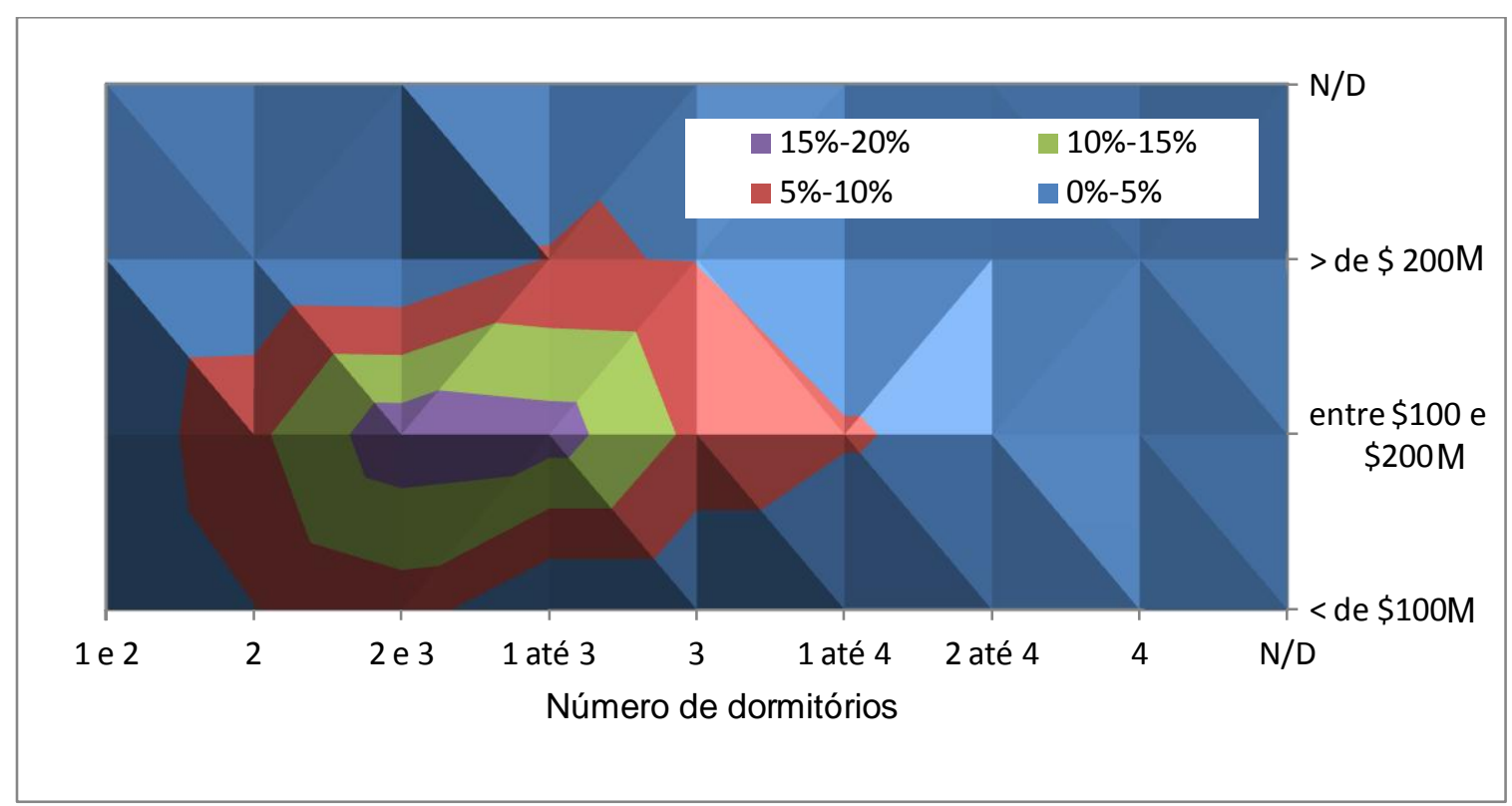

Fonte: Produção do próprio autor com dados da Fundação Promotora de Moradia (2013).

\section{Ameaça}

T.20. Concorrência local focada nos estratos de renda média-alta e alta, desenvolvendo alta habilidade nesses segmentos.

Analisando as facilidades e amenidades que apresentam esses projetos, distinguiuse 22 diferentes itens, entre: piscina com raias, jacuzzi, quadras, brinquedoteca, churrasqueira, deck, fitness, etc. Dando um ponto por cada item que o empreendimento possui individualmente, os resultados mostraram que a maioria dos projetos estavam na faixa entre 5 e 12 pontos.

A Tabela 4.12, mostra o cenário de dois elementos importantes entre as amenidades dos empreendimentos residenciais, como são as vagas de estacionamento e a piscina. 
Tabela 4.12 - Facilidades dos projetos imobiliários: piscina e estacionamento

\begin{tabular}{|c|c|c|c|c|c|}
\hline \multirow{2}{*}{$\begin{array}{l}\text { Preço aprox. da solução } \\
\text { habitacional (\$ Miles) }\end{array}$} & \multicolumn{3}{|c|}{ Vagas de estacionamento } & \multicolumn{2}{|c|}{ Piscina } \\
\hline & 1 vaga & 2 vagas & $N / D$ & Tem & Não tem \\
\hline$<$ de $\$ 100$ & $1,3 \%$ & $7,6 \%$ & $1,3 \%$ & $7,6 \%$ & $2,5 \%$ \\
\hline entre $\$ 100$ e $\$ 200$ & $7,6 \%$ & $46,8 \%$ & $7,6 \%$ & $50,6 \%$ & $11,4 \%$ \\
\hline$>$ de $\$ 200$ & $1,3 \%$ & $11,4 \%$ & $1,3 \%$ & $11,4 \%$ & $2,5 \%$ \\
\hline N/D & $3,8 \%$ & $10,1 \%$ & $0,0 \%$ & $10,1 \%$ & $3,8 \%$ \\
\hline Total & $14 \%$ & $76 \%$ & $10 \%$ & $80 \%$ & $20 \%$ \\
\hline
\end{tabular}

Fonte: Produção do próprio autor com dados da Fundação Promotora de Moradia (2013).

Como é mostrado pela Fundação Promotora de Moradia (2013) e outros autores como Fernández (2011), Barrantes (2012) e Camacho (2012), existe um gap ou desatendimento para as famílias de classe média-baixa e média. Sendo a maioria dos desenvolvimentos comerciais para rendas médias-altas e altas. ${ }^{29}$

\section{Oportunidades}

O.24. Níveis de renda médios estão desatendidos pela concorrência local de grandes projetos residenciais.

${ }^{29}$ Como referência, para que uma família opte por um financiamento de, aproximadamente, mais de US\$100 mil, esta dever ser constituída por duas pessoas com salário mínimo de formação superior, e ingresso total do lar de pouco mais de US\$ 2 mil. Ademais, não ter comprometido sua renda em outros empréstimos, como móveis, automóveis ou faculdades, por exemplo. 


\section{APLICAÇÃO DA ANÁLISE A VÁRIAS EMPRESAS BRASILEIRAS DE REAL ESTATE RESIDENCIAL}

O presente capítulo avalia a atratividade do mercado residencial costarriquenho como alvo para investimento de empresas brasileiras, e distingue os elementos de maior peso que influenciam nessa tomada de decisões. Para isso, utilizaram-se os elementos estratégicos obtidos da análise feita nos capítulos 3 e 4, elaborando um conjunto de informação que possa ser apresentada às empresas brasileiras.

Para cumprir o objetivo deste capítulo, foram entrevistadas onze empresas de grande e médio porte, com importante atuação no mercado residencial brasileiro. A descrição detalhadas dessas empresas será apresentada adiante.

\subsection{Sínteses das oportunidades e ameaças do mercado residencial costarriquenho}

Distinguiu-se da análise do mercado residencial da Costa Rica um total de 24 oportunidades e de 20 ameaças, as quais foram classificadas em três níveis de importância para o desempenho de negócios para as empresas de real estate residencial: baixo impacto, médio impacto e alto impacto.

Ao lado das oportunidades, foi dada a classificação de baixo impacto para aquelas condições que propiciam um bom ambiente para os negócios no país, quase indiferentemente do tipo de atividade que seja desenvolvida. Entre esta categorização encontra-se a maioria das conjunturas político-legais e socioculturais, e o ambiente econômico.

Foram designadas oportunidades de médio impacto, àquelas que são produto das conjunturas político-legais que impactam positivamente nos assentamentos humanos, melhorando o ambiente de negócios para empreendedores residenciais. 
Por último, as oportunidades de alto impacto correspondem àquelas próprias do mercado residencial, estas ligadas ao sistema de financiamento de moradia própria, novas tendências do mercado e segmentos com pouca concorrência.

Junto às ameaças, a classificação é muito similar à anterior, as de baixo impacto são aquelas que são produto das conjunturas do país, que agravam o ambiente para os negócios, ligados particularmente a condições de instabilidade econômica, aos entraves burocráticos e aos gargalos de competitividade.

As ameaças de médio impacto competem às condições próprias do sistema financeiro e ao regime de câmbio. Essas condições têm uma importante consequência em relação às atividades empreendedoras, especialmente para o real estate residencial.

Por último, entre as ameaças de alto impacto estão listadas aquelas que podem afetar diretamente os resultados das empresas de real estate, com queda nos cenários de vendas e preços das unidades residenciais, por exemplo. Entre estas estão o tamanho do mercado, os requisitos para empréstimos, e a atuação da concorrência.

\subsection{Sínteses das forças e fraquezas das empresas de real estate residencial}

Distinguiu-se da análise do ambiente interno das empresas de real estate residencial em processo de internacionalização 12 forças e 10 fraquezas.

Do total das forças, quatro delas correspondem àquelas características que ajudariam a internacionalizar o foco habitual de atuação das atividades da empresa; e oito àquelas habilidades próprias do negócio de real estate, as quais seriam indispensáveis no novo mercado a ser explorado. 
Entre as fraquezas, foi feita a mesma divisão, sendo oito os elementos que dificultariam a migração das atividades da empresa e dois, os fatores próprios desses tipos de empresas que influenciariam no desempenho delas no exterior.

\subsection{Descrição do questionário dirigido às empresas de real estate}

O Apêndice A mostra o questionário que foi dirigido às empresas brasileiras de real estate residencial. Este apresenta, na primeira parte, de maneira sintetizada, a informação do mercado costarriquenho, divididas em oportunidades e ameaças.

A segunda parte se inicia com a tomada de decisões sobre o interesse da empresa entrevistada em internacionalizar suas atividades para o mercado da Costa Rica e a atratividade deste; depois dessa etapa, mede-se a importância de cada oportunidade e ameaça do mercado nessa decisão.

Na última parte do questionário, são apresentadas as forças e fraquezas do ambiente interno de empresas de real estate residencial em processo de internacionalização. Nessa parte, as empresas entrevistadas identificaram quais desses atributos e condições estão presentes nelas.

\subsection{Empresas entrevistadas}

Para aplicar o questionário, foi encontrado como fator limitante o tipo de profissional capaz de responder a este, pois deveriam, por meio da ótica da empresa, avaliar as informações apresentadas sobre mercado costarriquenho e que pudessem respondê-lo segundo a possível reação da empresa. Além disso, deveriam conhecer as características e competências relativas ao desempenho da empresa com relação às suas atividades no mercado local, nos últimos anos.

Somado a isso, as empresas entrevistadas deveriam ter condições de estrutura e recursos, de maneira que fosse possível considerar a realização desse tipo de 
empreendedorismo, além de mostrar interesse na pesquisa. Reduzindo com isso as possíveis empresas que poderiam responder o questionário.

A partir dessas circunstâncias, o total de empresas nas quais se aplicou o questionário foi de onze, o perfil dessas empresas e o profissional entrevistado são descritos (em ordem alfabética) a seguir:

- Brookfield Incorporações (Diretor Executivo): fundada em 2009 com a aquisição da MB Engenharia pela Brascan Residencial Properties e fusão com a Company S/A. Brookfield Incorporações é uma das maiores empresas de real estate residencial do Brasil com aproximadamente 3,5 mil colaboradores. Empresa de capital aberto e com atuação nos estados de Rio de Janeiro, São Paulo, Brasília, Goiás e Mato Grosso, opera nos segmentos de renda econômico, médio-baixo, médio, médio-alto e alto, além do segmento comercial. Atualmente, essa empresa soma mais de 26 milhões de metros quadrados de construção desenvolvidos nos segmentos residencial e comercial, com mais de 73 mil unidades entregues (BROOKFIELD, 2014). O Anexo A amplia o desenvolvimento e atuação dessa empresa nos anos de expansão geográfica e de produtos.

- Camargo Corrêa Desenvolvimento Imobiliário (Diretor de Incorporação): parte de uns dos maiores grupos empresariais privados do Brasil, o Grupo Camargo Corrêa. CCDI é uma empresa de grande porte, de capital aberto até 2012 quando saiu da bolsa de valores fechando o capital. Desenvolve projetos residenciais e comerciais destinados ao segmento corporativo, com operações em 20 estados brasileiros e presença em 17 países. No segmento residencial opera no alto padrão, com atuação nos principais estados do Rio de Janeiro, São Paulo, Paraná e Minas Gerais; atua também no segmento econômico por meio da HM Engenharia, empresa com foco exclusivo nesse mercado. Chegaram a 2014 com $R \$ 10,5$ bilhões de VGV lançados e 51 empreendimentos entregues (CAMARGO CORRÊA DESENVOLVIMENTO IMOBILIÁRIO, 2014). O Anexo A amplia o desenvolvimento e atuação dessa empresa nos anos de expansão quando era de capital aberto. 
- CIPASA Urbanismo (CFO Diretor Financeiro e Administrativo): loteadora fundada em 1991, especialista em desenvolvimento urbano com planejamento, tem em seu histórico a aquisição de empresas como a Atuarq Desenvolvimento Urbano e a Colorado Empreendimentos Imobiliários. Atualmente CIPASA é controlada por umas das maiores gestoras de private equity, HSI Investimentos. Com operações no Amapá, Bahia, Espírito Santo, Pará, Piauí, Rio de Janeiro, Rio Grande do Sul, Rondônia, Santa Catarina e São Paulo, somam mais de 190 projetos lançados ou em desenvolvimento, e seus projetos atendem a todas as faixas de renda no Brasil (CIPASA, 2014).

- Cury Construtora e Incorporadora S.A (Diretor de Relações Institucionais): empresas com experiência no mercado residencial brasileiro desde 1962, em 2007 passa a ser Cury Construtora e Incorporadora S.A, depois de uma jointventure entre Cury Empreendimentos e Cyrela Brazil Realty. Atualmente, consolidada como uma das maiores construtoras do Programa Minha Casa Minha Vida, tem como foco principal o segmento residencial supereconômico, econômico e meio econômico em São Paulo e Rio de Janeiro. Em 2013 contabilizou 20,8 mil unidades produzidas (mesma quantidades de unidades que absorve o mercado residencial costarriquenho, segundo nossa análise) e projeta para 2014 fechar em 27 mil unidades residenciais (CURY, 2014).

- EZTEC Empreendimentos e Participações S/A (Diretor Financeiro e de Relações com Investidores): construída como sociedade anônima em 2006, faz parte EZTEC, grupo com mais de 40 anos de experiência nos setores imobiliário, hoteleiro e agropecuário. Empresa de grande porte, de capital aberto, com operações em mais de 40 bairros de São Paulo e região metropolitana, seu foco é médio e alto padrão, somando mais de 21 mil unidades habitacionais ou 3 milhões de metros quadrados construídos (EZTEC, 2014). Esta empresa no primeiro trimestre de 2014 registrou a maior relação preço/patrimônio líquido $(1,7)$ nos últimos 12 meses. O Anexo A amplia o desenvolvimento e a atuação desta empresa nos anos de expansão geográfica e de produtos.

- Living (Diretor de Incorporação): parte do grupo Cyrela Brasil Realty, uma das maiores empresas de real estate no Brasil, empresa de capital aberto, com 
mais de 50 anos de história e operações em 17 estados e 55 cidades do Brasil; além de contar com participações na Argentina e no Uruguai. Em 2006, nasce a marca Living voltada para os segmentos econômico e supereconômico, atualmente seu foco de atuação são as rendas médias (CYRELA, 2014). No primeiro trimestre de 2014, a CYRELA registrou o maior número de lançamentos entre as empresas listadas na bolsa de valores do Brasil, com 1.720, 207\% mais que os lançamentos registrados no primeiro trimestre de 2013. O Anexo A amplia o desenvolvimento e atuação da CYRELA e a participação da Living nos anos de expansão geográfica e de produtos.

- Rocontec (Diretor Executivo e Sócio): construtora de médio porte, formada por sócios que exerceram importante papel no desenvolvimento da engenharia no Brasil, por mais de três décadas. Com operações nos bairros da região metropolitana de São Paulo, seu foco é de médio e alto padrão (ROCONTEC, 2014).

- RRG Construtora (Diretor): atuante no estado de São Paulo nas áreas de construção e incorporação no setor residencial para rendas médias e altas. Incluem em seus projetos casas de altíssimo padrão, condomínios e edifícios residenciais, além de atuações em parceria com grandes incorporadoras e imobiliárias (RRG, 2014).

- VBI Real Estate (Sócio): Empresa gestora de fundos de private equity com foco no setor imobiliário, localizada em São Paulo e pertencence inteiramente a seus sócios fundadores. Desde sua fundação, em 2006, os fundos administrados pela VBI Real Estate receberam montantes de, aproximadamente, US $\$ 800$ milhões, provenientes de diversos fundos, seguradoras, fundações e de pessoas físicas. Os ativos de seus fundos são encontrados principalmente em São Paulo e Rio de Janeiro, mas também, no Rio Grande do Norte, em Natal, e no Paraná (VBI REAL ESTATE, 2014).

Duas das empresas entrevistadas pediram sigilo de sua participação na pesquisa, portanto uma breve descrição delas e sua relevância no setor residencial serão apresentadas: 
- Empresa A: com mais de 100 anos de história em São Paulo, formada por investidores estrangeiros e brasileiros, reconhecida no mercado brasileiro pela atuação no planejamento de bairros, projetos e requalificação de áreas urbanizadas. Com investimentos em vários países de América do Sul.

- Empresa B: de capital aberto de grande porte, fundada há mais de 10 anos, com atuação concentrada nas regiões metropolitanas dos estados do Rio de Janeiro, Minas Gerais, São Paulo e Rio Grande do Sul, opera no segmento residencial de média renda e alto padrão, além do segmento comercial.

Embora as empresas entrevistadas serem dedicadas a diferentes atividades no setor residencial e atenderem distintos segmentos de renda, a maioria das respostas e conclusões sobre o tema, dadas pelos entrevistados, convergirão em uma posição muito similar. Portanto, considera-se que foi capturada a percepção geral da maioria das empresas brasileiras no caso de uma expansão internacional.

\subsection{Principais resultados das entrevistas}

O resumo dos principais resultados é mostrado nos seguintes pontos, adicionados de comentários feitos pelos entrevistados no momento em que respondiam ao questionário.

\subsubsection{Interesse no mercado da Costa Rica}

Quando se perguntou sobre o interesse da empresa em internacionalizar suas atividades para o mercado da Costa Rica, segundo as informações apresentadas, a maioria das respostas foram negativas. As razões disso serão discutidas, posteriormente, no desenvolvimento dos outros itens.

A única empresa que mostrou interesse no mercado costarriquenho se deve ao fato de ser uma empresa com um perfil internacional, portanto não há problemas em analisar esse novo mercado entre seus possíveis mercados de atuação. 
Figura 5.1 - Interesse em estudar o mercado da Costa Rica

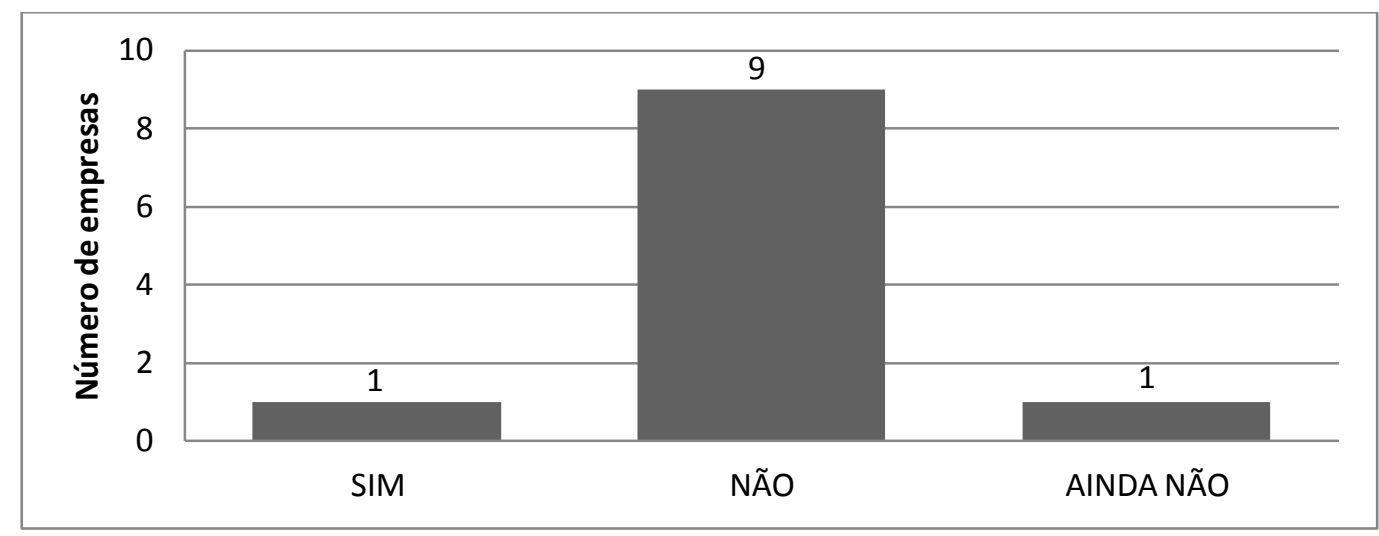

Fonte: Produção do próprio autor.

\subsubsection{Tipo de informação apresentada}

Quando foi perguntado sobre a qualidade das informações apresentadas, "empresas de nicho" mostraram desinteresse em relação a elas, pois a internacionalização não é um de seus objetivos atuais. O restante das empresas concordou que, para uma resposta negativa, as informações apresentadas seriam suficientes, mas no caso do mercado apresentar elementos atrativos a elas, seriam necessárias maiores informações, ao que concerne aos interesses específicos da empresa e à elaboração de relatório mais amplo, para a devida discussão.

Figura 5.2 - Qualidade da informação

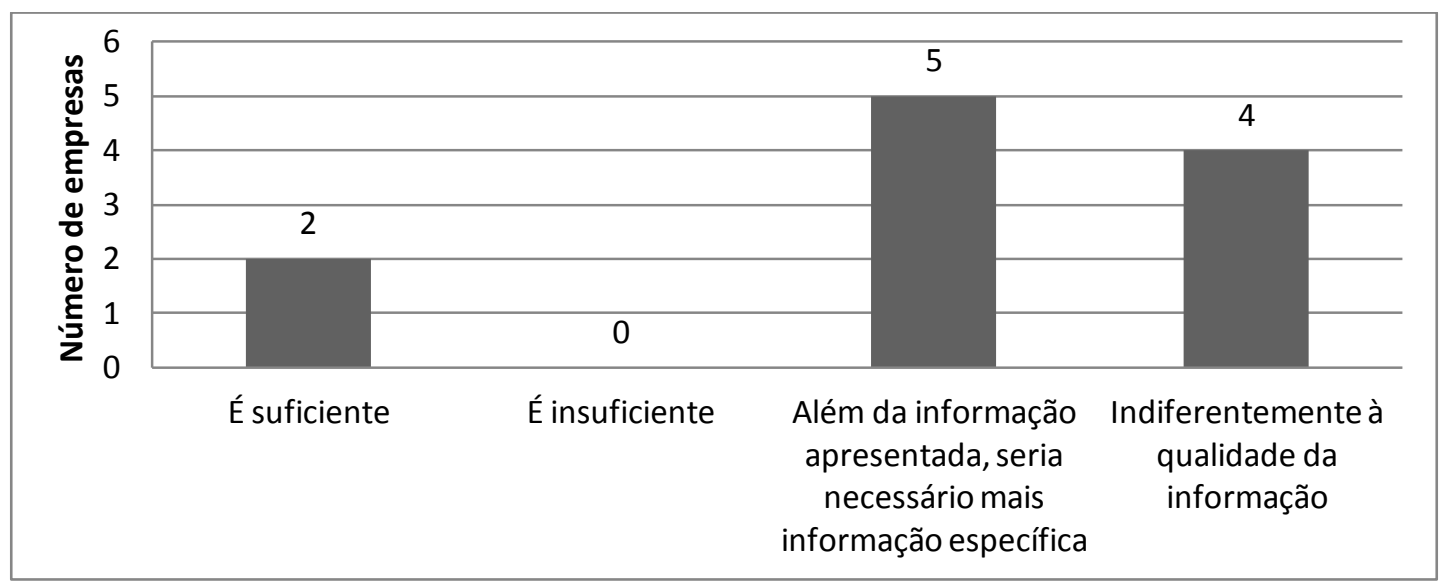

Fonte: Produção do próprio autor.

\subsubsection{Atratividade do mercado}

O desinteresse nesta estratégia se evidenciou quando foi perguntado sobre a atratividade do mercado costarriquenho, que recebeu classificação de "pouco 
atrativo", em sua maioria. As empresas entrevistadas não encontram nenhuma oportunidade ou vantagem de alto valor que torne o mercado costarriquenho atrativo.

Figura 5.3 - Atratividade do mercado costarriquenho

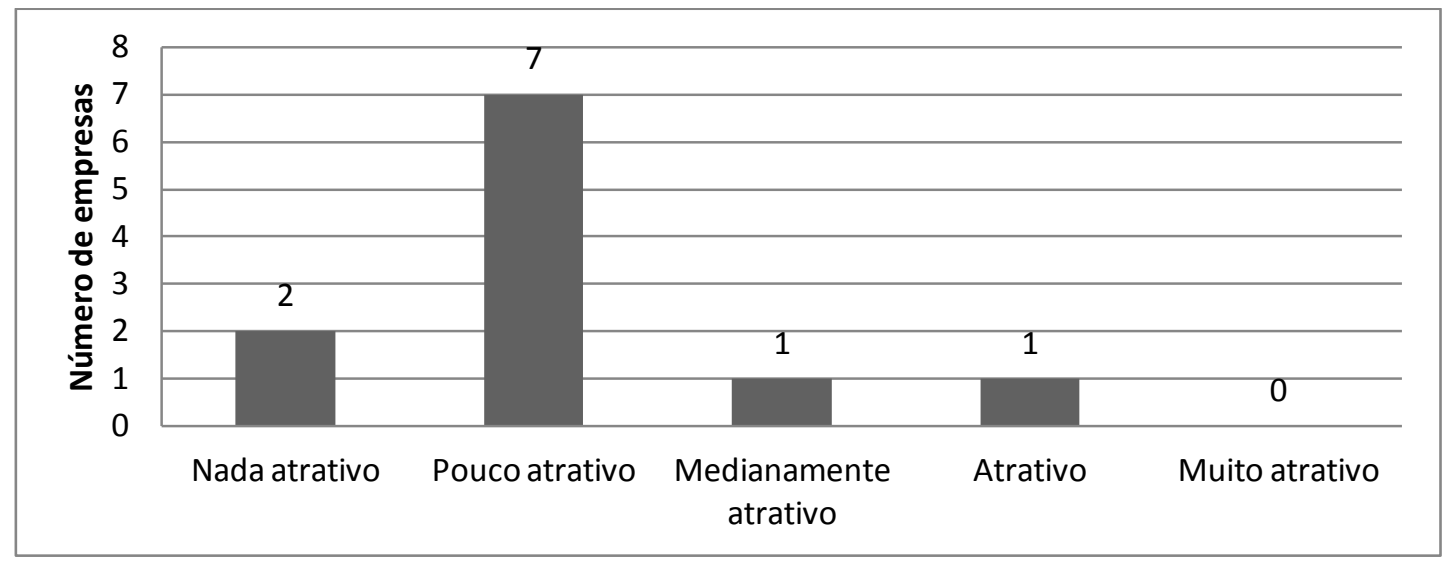

Fonte: Produção do próprio autor.

\subsubsection{Importância das oportunidades e ameaças do mercado}

Para a apresentação dos dados, as ameaças e oportunidades classificadas em um primeiro instante de baixo e médio impacto, correspondente ao cenário macroeconômico e às conjunturas político-legais e socioculturais foram agrupadas como "ambiente país", este recebeu na média, pontuações em torno de 3,5 (entre medianamente importante e importante). Enquanto os fatores próprios do mercado receberam maior atenção pelas empresas, com uma pontuação em torno de 4,0 (importante).

A escala designada no questionário para cada oportunidade e ameaça está detalhada embaixo da Tabela 5.1.

Nota-se que as ameaças foram mais significativas no momento da tomada de decisões, com pontuação maior que as oportunidades em todos os casos, o que explica o desinteresse nessa estratégia. 
Tabela 5.1 - Importância das oportunidades e ameaças na tomada de decisões

\begin{tabular}{ccc}
\hline Elementos externos & Oportunidades & Ameaças \\
\hline Ambiente país & 3,36 & 3,59 \\
Próprios do mercado & 3,86 & 4,05 \\
\hline Total & $\mathbf{3 , 7 6}$ & $\mathbf{3 , 9 5}$ \\
\hline
\end{tabular}

Nota: escala designada no questionário: 1 - nada importante, 2 - pouco importante, 3-medianamente importante, 4 - importante, 5 - imprescindível

Fonte: Produção do próprio autor.

Os resultados da avaliação de cada uma das oportunidades e ameaças da entrevista são mostrados na Tabela 5.2.

Tabela 5.2 - Valoração das oportunidades e ameaças do mercado costarriquenho

\begin{tabular}{lc}
\hline \multicolumn{1}{c}{ Elementos avaliados } & $\begin{array}{c}\text { Pontuação } \\
\text { média }\end{array}$ \\
\hline As oportunidades de baixo impacto & 3,5 \\
\hline As oportunidades de médio impacto & 3,3 \\
\hline As ameaças de baixo impacto & 3,4 \\
\hline As ameaças de médio impacto & 3,8 \\
\hline \multicolumn{1}{c}{ Oportunidades de alto impacto } & 4,0 \\
\hline Poder aquisitivo dos lares costarriquenhos & 3,5 \\
\hline Carência residencial do país & 3,7 \\
\hline Crescimento e características dos lares costarriquenhos & 4,5 \\
\hline Diversas alternativas de financiamento para empresas e público & 4,2 \\
\hline Baixas taxas de juros do mercado costarriquenho para créditos & 3,5 \\
\hline $\begin{array}{l}\text { Aumento nas tendências de moradia para apartamentos e } \\
\text { condomínios }\end{array}$ & 3,7 \\
\hline Níveis de renda médios desatendidos pela concorrência local & 3,8 \\
\hline Características da atuação da concorrência local & \\
\hline
\end{tabular}

Ameaças de alto impacto

\begin{tabular}{lc}
\hline O tamanho do mercado residencial & 4,5 \\
\hline A cultura instalada & 3,6 \\
$\begin{array}{l}\text { Os entraves do sistema financeiro para créditos a empresas de } \\
\text { real estate residencial }\end{array}$ & 4,5 \\
$\begin{array}{l}\text { Os entraves do sistema financeiro para créditos de moradia } \\
\text { própria }\end{array}$ & 4,6 \\
\hline Pouca ou carência de poupança acumulada pelas famílias & 4,3 \\
\hline
\end{tabular}




\begin{tabular}{ll}
\hline costarriquenhas & 3,8 \\
$\begin{array}{l}\text { Diminuição dos recursos colocados pelos bancos para construção } \\
\text { de moradia }\end{array}$ & 3,4 \\
\hline $\begin{array}{l}\text { Autonomia do setor empresarial local de real estate residencial } \\
\text { Domínio das rendas médias-altas e altas pela concorrência local }\end{array}$ & 3,7 \\
\hline
\end{tabular}

Fonte: Produção do próprio autor.

A nomenclatura entre parênteses a ser usada daqui em diante, corresponde à oportunidade $(\mathrm{O})$, ameaça $(\mathrm{T})$, força $(\mathrm{S})$ ou fraqueza $(\mathrm{W})$ que derivou o item avaliado no questionário.

Entre as oportunidades mais significativas para a tomada de decisões estão: "as diversas alternativas de financiamento para empresas e público" (O.19 e O.20) com 4,5, e as "baixas taxas de juros do mercado costarriquenho para créditos" (O.21) com 4,2.

Com relação às ameaças, as de maior influência foram: "os entraves do sistema financeiro para créditos de moradia própria" (T.16) com 4,6; “os entraves do sistema financeiro para conceder créditos a empresas de real estate residencial” (T.15) com 4,5; “o tamanho do mercado residencial” (T.11) com 4,5, e "a pouca ou carência de poupança acumulada pelas famílias costarriquenhas" (T.17) com 4,3.

Uma população pequena e, além disso, restringida de sua capacidade de acessar aos créditos para moradia própria, foram as principais razões justificadas pelas empresas para não se expandir à Costa Rica, concluindo que a soma disso dá como resultado, um mercado "pequeno", pouco atraente, sobretudo quando se compara com o mercado brasileiro onde elas atuam.

Mudanças na cultura instalada, a carência residencial do país e autonomia do setor residencial local receberem notas igual ou abaixo de 3,5, pois sua importância para as empresas entrevistadas não é de grande relevância. 


\subsubsection{Forças e fraquezas das empresas}

Quando se perguntou sobre as forças que ajudariam as empresas de real estate no processo de internacionalização, das 12 forças elencadas, as quatro mais comuns para as empresas foram:

i. “a empresa possui competências nas áreas de project e construction management" (S.9) em 9 das 11 empresas;

ii. "a empresa pode reconhecer o risco de seus investimentos, antes e durante cada ciclo de investimento/retorno" (S.7), em 8 das 11 empresas;

iii. "a empresa possui boa gestão dos recursos financeiros na área contábil, de finanças corporativas e de tributos" (S.8) em 8 das 11 empresas.

iv. "entendimento dos ciclos e processos do mercado local, refletindo um adequado planejamento, desenho e marketing do produto, cumprindo as expectativas dos clientes" (S.5) em 7 das 11 empresas;

v. "capacidade de criar novas competências dependendo das condições do mercado e da estratégia implementada" (S.1) em 7 das 11 empresas.

Essas forças, em sua maioria, correspondem às habilidades básicas e de desempenho para empresas de real estate, segundo a literatura consultada (GIBLER et al., 2002; MANNING; EPLEY, 2006; LINJIE, 2011), o qual supõe que grande parte das empresas entrevistadas contam com um primeiro passo para 0 processo de internacionalização, com o domínio das habilidades próprias de seu setor.

Mas mesmo que haja domínio dessas competências, muitas empresas não objetivam a internacionalização, devido às atuais condições favoráveis de seus mercados locais, sendo pouco atraente experimentar novos riscos, desnecessariamente.

Entre as 10 fraquezas elencadas, a grande maioria concordou (7 das 11 empresas) que um obstáculo para a internacionalização tanto na Costa Rica como em qualquer país seria que "a cultura empresarial da companhia possui muitos traços 
próprios da cultura "regional", que interferem no desenvolvimento das atividades de negócios com pessoas de outros países e cultura” (W.1).

Além disso, concordaram que outro obstáculo seria o "recurso econômico limitado ou insuficiente para internacionalizar a empresa" (W.8) (4 das 11 empresas) e "a estrutura administrativa rígida da empresa, desenhada unicamente para seu nicho de atuação" (W.4) (3 das 11 empresas). O restante das respostas foi com pontuações menores.

O total dos resultados das forças e fraquezas da entrevista é mostrado no Apêndice B.

\subsubsection{Outras observações}

Entre outras observações feitas pelas empresas, destaca-se a carência de um driver sólido que as conduzam a esse mercado. Tamanho de mercado, culturas, línguas, distância geográfica, carência de conhecimento local ou de parceiros locais conhecidos, produtividade e diferenças no custo do dinheiro seriam obstáculos ao ganho atrativo de lucro comparado ao risco incidido.

Além disso, várias empresas não se interessam em deslocamentos internacionais, porque as condições econômicas e as dimensões do mercado residencial brasileiros ainda propiciam oportunidades para que os objetivos empresariais planejados em médio prazo possam ser atingidos, com espaço suficiente para as empresas continuarem seu crescimento.

Por último, os mercados mais geograficamente próximos e com vantagens mais tangíveis, como as oferecidas nos países do MERCOSUL (Mercado Comum do Sul), seriam os primeiros alvos, em caso de internacionalização das atividades empresariais brasileiras.

Mercados internacionais distantes poderiam ser atraídos enquanto forem percebidos menos riscos nesse tipo de negócio, por exemplo, com garantia de quantidade considerável de unidades a desenvolver, e facilidades no fornecimento de materiais 
e mão de obra por parte de terceiros: governo, organizações internacionais, investidores locais, entre outros.

\subsection{SWOT das empresas entrevistadas}

Da análise de base SWOT proposta para estudar uma possível expansão de empresas brasileiras de real estate residencial no mercado costarriquenho, obtevese a seguinte figura como resultado da pesquisa realizada às empresas do setor residencial brasileiro entrevistadas.

Figura 5.4 - SWOT das empresas entrevistadas

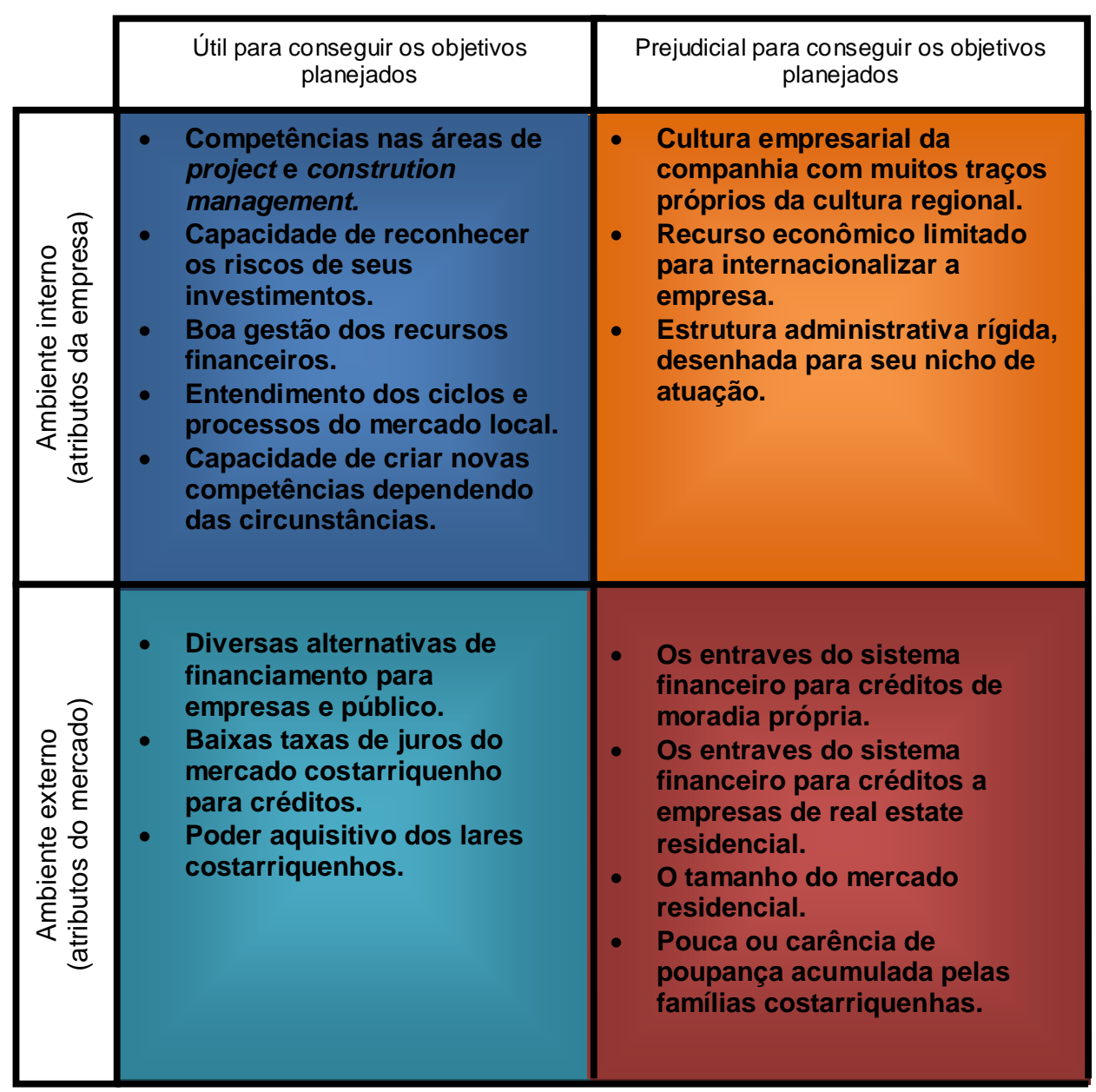

Fonte: Produção do próprio autor. 


\subsection{Discussão de resultados}

Os resultados das entrevistas mostraram que os entrevistados consideram de grande valor para se internacionalizarem o desenvolvimento do conhecimento local, uma característica muito própria do real estate residencial, percebendo um risco muito alto quando se carece deste; e não é para menos, a carência desse conhecimento seria um dos principais motivos que aumentam a chance de demora nas obras, além de sobrecustos e de operações instáveis das empresas que levam suas operações a níveis internacionais (LORD; RANFT, 2000).

O problema do conhecimento local é amplo, particularmente para empresas do setor residencial, as quais precisam das informações mercadológicas, legais e técnicas nos processos de tomada de decisões. Por isso, vários pesquisadores têm se aprofundado nesta problemática, como Javernick-Will (2009), que estuda como as incorporadoras, empreiteiras e outras empresas de real estate coletam 0 conhecimento institucional local durante sua atuação internacional.

Sempre no ambiente interno, a pesquisa mostrou que as empresas entrevistadas consideram ter consolidadas suas competências essenciais como empresas de real estate residencial, mas nenhuma força útil para a organização do processo de internacionalização, aparentemente nas passadas experiências de expansão, não se desenvolveram competências que possam ser utilizadas para estratégias internacionais.

Do lado do ambiente externo, apesar das oportunidades do mercado costarriquenho, o risco intrínseco do real estate residencial, somado às incertezas das novas ameaças, não tornam esse mercado atrativo para considerá-lo como possível mercado de atuação, ainda mais, com as atuais dimensões de população, o nível de oferta máxima e os entraves do sistema creditício para o setor residencial da Costa Rica.

Esses fatores poderiam criar processos de recessão no setor residencial (e.g. recessão do crédito para moradia própria), que evitariam a obtenção de resultados 
desejados, sendo que o capital investido em uma estratégia de internacionalização, por seu alto grau de risco, deveria ter um ganho de igual magnitude.

Os entrevistados, desde uma visão estratégica, reconhecem a importância de equacionar os meios e fontes de recursos para alcançar os objetivos planejados, baseado em suas experiências passadas, situação que se mostrou evidente com os resultados do questionário, dando as maiores pontuações de importância a essas ameaças.

Por último, na tomada de decisões sobre investir no mercado da Costa Rica, incidiu muito o significativo potencial de consumo do mercado doméstico brasileiro, o que retarda ou descarta a internacionalização das empresas segundo Dal-Soto, Alves e Bulé (2014). Além disso, as desmotivações empresariais pelas dificuldades originadas do isolamento geográfico e linguístico (ROCHA, 2003 apud DAL-SOTO; ALVES; BULÉ, 2014), o que criam uma distância psíquica significativa entre o Brasil e a Costa Rica, para que empresas sem nenhum conhecimento de internacionalização realizem investimento direto estrangeiro.

Portanto, o Modelo Uppsala, proposto como embasamento do processo de internacionalização para estas empresas, explicaria 0 motivo da não internacionalização das empresas desse setor, pois não se criaram competências, nem acumularam aprendizagens de suas passadas experiências, e porque seus mercados domésticos não apresentam saturação que motive a estas a sair à procura de novos negócios. 


\section{CONCLUSÕES}

Da análise de base SWOT proposta para estudar uma possível expansão de empresas brasileiras de real estate residencial no mercado costarriquenho, foram identificadas, teoricamente, no ambiente interno de empresas desse tipo, 12 forças e 10 fraquezas para estratégias de internacionalização, e no ambiente externo, 24 oportunidades e 20 ameaças. Desses elementos, obteve-se o seguinte quadro SWOT com os elementos mais destacáveis, segundo as empresas brasileiras entrevistadas.

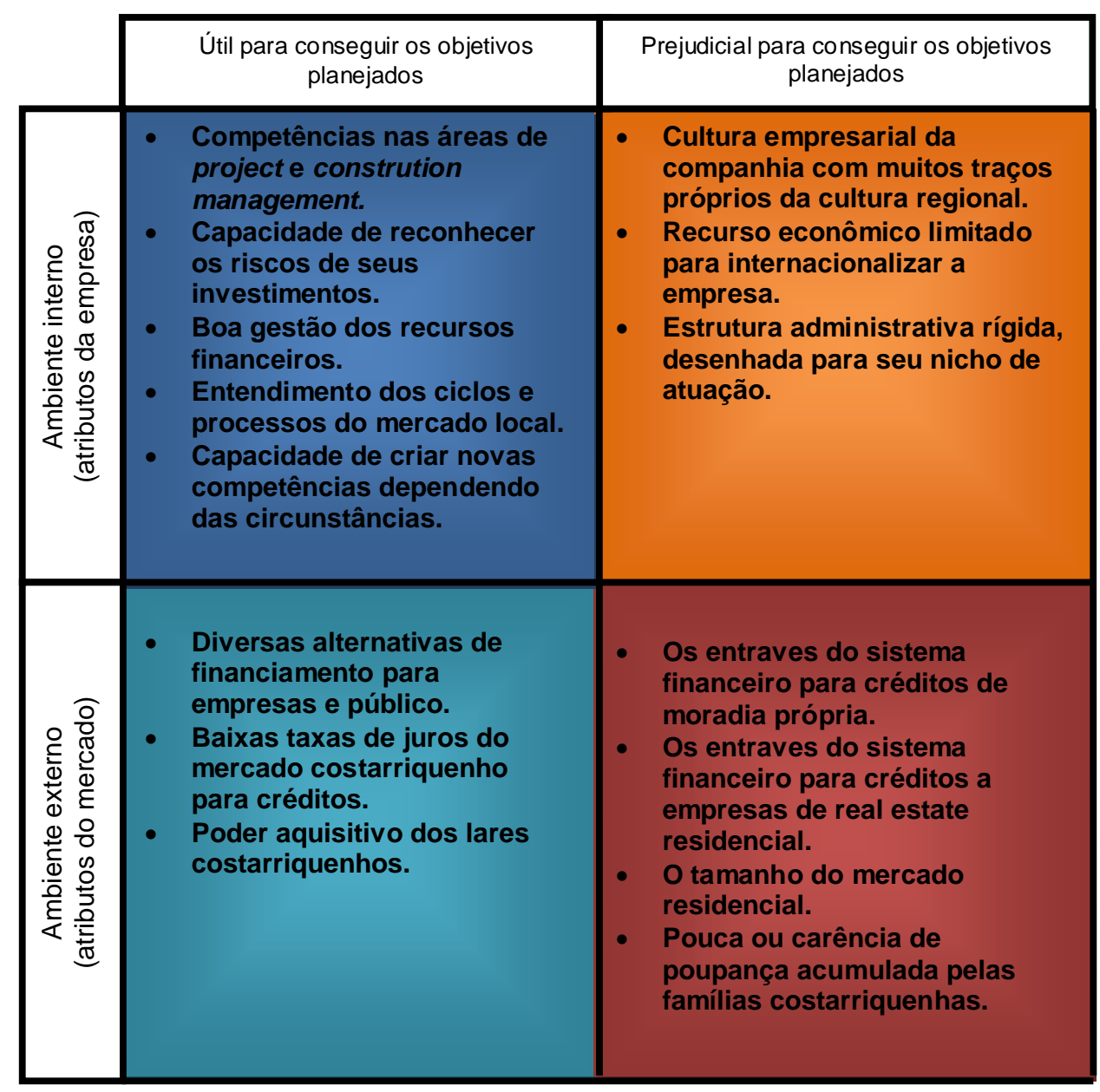

Conclui-se sobre a possível internacionalização de empresas brasileiras de real estate residencial para o mercado costarriquenho, que desde uma perspectiva econômica-racional (de custos e vantagens econômicas de produção) poderia se explicar parte desse fenômeno. Pois, apesar de existirem oportunidades para o desenvolvimento de projetos residenciais de alta densidade populacional, 
especialmente nos centros urbanos deprimidos, onde se concentram as maiores atividades econômicas, nenhuma pode figurar como um driver econômico sólido, atraente de investimento estrangeiro, segundo os entrevistados.

Ainda assim, a decisão geral de não investir no mercado da Costa Rica pelas empresas entrevistadas teve principalmente um caráter contingencial, pois são considerados os interesses entre os mercados internos e externos para a tomada de decisões, procurando a redução dos riscos na operação. Destaca-se como pontos importantes:

- as condições dos mercados locais das empresas brasileiras, que não propiciam a saída deste; sendo esse motivo o responsável das principais fraquezas identificadas. Além, as empresas entrevistadas justificam um melhor uso de suas forças em seus mercados locais, com reengenharias e inovação de seus produtos;

- não foram desenvolvidas competências essenciais úteis para processos de expansão geográfica internacional nas experiências passadas;

- as ameaças do mercado costarriquenho são maiores às de seus mercados habituais, e o prejuízo destas são conhecidas pelas empresas brasileiras.

Conclui-se da análise que não é viável nem vantajoso idealizar um processo de internacionalização para o mercado da Costa Rica de empresas brasileiras de real estate residencial sob as condições antes citadas, sendo possível visualizar algum processo no futuro, se essas condições mudarem.

\subsection{Considerações finais sobre o mercado residencial costarriquenho}

Principalmente pela dimensão do mercado costarriquenho, este carece de uma atratividade para empresas brasileiras, segundo foi corroborado nas entrevistas. Ainda assim, embora empresas estrangeiras não desejem percorrer o risco de entrar nele, a dinâmica deste mercado poderia aumentar, e o capital estrangeiro poderia ser atraído para o desenvolvimento de projetos imobiliários, incentivando a criação de Fll ou instrumentos similares, liberando maior crédito para empresas e pessoas. 
Em segundo lugar, apesar das condições para um crédito de moradia na Costa Rica não apresentarem as grandes limitantes que se mostraram no mercado residencial brasileiro anos atrás, fica a dúvida, se as poucas opções de projetos em localizações metropolitanas são devido aos altos custos da engenharia ou a um mercado alvo com pouco poder de compra. Pois, da análise de absorção de mercado, nota-se que este não tem tido um crescimento significativo desde a recuperação da queda da Crise de 2008.

Por último, apesar de muitas empresas entrevistadas não verem o mercado costarriquenho como atrativo, várias delas concordaram que empresas especializadas em projetos de alta densidade de interesse social ou classe média poderiam ser atraídas por este mercado, sempre e quando se conta com a ajuda do governo, em vistas de diminuir o déficit habitacional e melhorar a dinâmica das cidades. 


\section{REFERÊNCIAS}

ALENCAR, C. $T$ de. A tomada de decisões estratégicas no segmento de empreendimentos residenciais: uma sistêmica de análise. 1993. 328 p. Dissertação (Mestrado em Engenharia) - Escola Politécnica, Universidade de São Paulo, São Paulo, 1993.

ALON, I.; BIAN, K. Real estate franchising: The case of Coldwell Banker expansion into China. Business Horizons, v. 48, n. 3, p. 223-231, maio. 2005.

ANSOFF, I. Estratégia Empresarial. Tradução de Antônio Zoratto Sanvicente; Revisão Técnica: Eduardo Vasconcellos e Jacques Marcovitch. São Paulo: McGraw-Hill do Brasil, Ltda. 1977.

BAC SAN JOSÉ. Crédito: Crédito Vivienda. Comercial. Disponível em: $<$ https://www.bac.net /bacsanjose/esp/banco/personas/Condiciones-Vivienda.html>. Acesso em: 4 abr. 2014.

BANCO CENTRAL DE COSTA RICA. Indicadores Económicos. Econômico. Disponível em: <http://www.bccr.fi.cr/indicadores economicos />. Acesso em: 11 out. 2013.

BANCO CENTRAL DO BRASIL. Economia e finanças. Econômico. Disponível em: $<$ https://www. bcb.gov.br/?SELICTAXA >. Acesso em: 20 mar. 2014.

BANCO DA COSTA RICA. Banco de Costa Rica BCR: Información Crediticia. Comercial. Disponível em: <https://www.bancobcr.com/empresas/cuentas\%20corrientes /Informacion\%20Crediticia.html>. Acesso em: 4 nov. 2014.

Banco de Costa Rica: Banca de Inversión. Comercial. Disponível em: $<$ https://www.bancobcr.com/empresas/banca\%20de\%20inversion/index.html >. Acesso em: 4 maio. 2014.

BARDHAN, A.; KROLL, C. A. Globalization and the Real Estate Industry: Issues, Implications, Opportunities. In: SLOAN INDUSTRY STUDIES ANNUAL CONFERENCE, 2007, Cambridge: Haas School of Business, UC Berkeley. Anais... 2007. 36 p. Disponível em: <http://web.mit.edu/sis07/www/kroll.pdf>. Acceso em: 30 jan. 2014.

BARNEY, J. Firm Resources and Sustained Competitive Advantage. Journal of Management, v. 17, n. 1, p. 99-120, 1 mar. 1991.

BARRANTES, A. C. Torres de condominios cambian San José con la vida en altura. 2012. Disponível em: <http://www.nacion.com/nacional/comunidades/Torres-condominioscambian-San-Jose 0 1310269108.html>. Acesso em: 28 nov. 2013.

BORINI, F. M.; FLORIANI, D. E.; FLEURY, M. T. L. Relação entre tamanho e desenvolvimento de competências organizacionais em multinacionais brasileiras. Revista de Administração da Universidade de São Paulo, v. 47, n. 4, p. 596-608, 2012. Disponível em: <http://www.rausp.usp.br/busca/artigo.asp? num artigo=1493> DOI: 10.5700/rausp1061. Acceso em: 29 de abril. 2015.

BRENES, C. Llegan nuevos desarrollos de uso mixto a Heredia y San José. Disponível em: <http://www.elfinancierocr.com/negocios/Desarrollos de uso mixto-Belen CenterBambu-La Estacion-nuevos proyectos-centro comercial 0 477552285.html>. Acesso em: 7 abr. 2014. 
BROOKFIELD. Brookfield Brasil. Página Web de Brookfield. Disponível em: <http://www. br.brookfield.com/Brookfield/nossahistoria/SP >. Acesso em: 4 nov. 2014.

BUCKLEY, P.J.; CASSON, M. The Future of the Multinational Enterprise. Londron: McMillan, 1976

CAMACHO, C. Torres residenciales toman capital. Disponível em: $<$ http://www.elfinancierocr.com/negocios/Torres-residenciales-toman-capital 014158585

5.html>. Acesso em: 7 abr. 2014.

CAMARGO CORRÊA DESENVOLVIMENTO IMOBILIÁRIO. Camargo Corrêa Desenvolvimento Imobiliário. Página Web de CCDI. Disponível em: $<$ http://www.ccdi.com.br/a-empresa $>$. Acesso em: 2 nov. 2014.

CIPASA. CIPASA Urbanismo. Página Web de CIPASA. Disponível em: $<$ http://www.cipasa.com/institucional/>. Acesso em: 4 nov. 2014.

COMITÉ DE MERCADO EPUSP. No cenário atual do mercado de Real Estate quais são as competéncias-chave para as incorporadoras? as atividades de produção são essenciais?. Nota da reunião de Maio do Comitê de Mercado. Escola Politécnica da Universidade de São Paulo. 2012.

CONSELHO MONETARIO CENTROAMERICANO. Informe de Riesgo País - IV Trimestre2013. Secretaría Ejecutiva - Consejo Monetario Centroamericano (CMC), 2013.

COSTA RICA. Constitución (1949). Constitución Política de la República de Costa Rica. San José: Palacio Nacional. Asamblea Legislativa de la República de Costa Rica. 1949.

N 1644 y sus reforma. Ley Orgánica Del Sistema Bancario Nacional. 26 set. 1953. Disponível em: <http://www.pgr.go.cr/scii/scripts/TextoCompleto.dll?Texto\&nNorma= 9925\&nVersion=10622\&nTamanoLetra=10\&strWebNormativa=http://www.pgr.go.cr/scij/\&str ODBC=DSN=SClJ NRM;UID=sa;PWD=scij;DATABASE=SCIJ NRM;\&strServidor=llpgr04\& strUnidad=D:\&strJavaScript=NO>. Acesso em: 5 abril 2014.

№ 7558. Ley Orgánica Del Banco Central. 11 mar. 1995. Disponível em: <http://www.hacienda.go.cr/centro/datos/Ley/Ley\%207558-Ley\%20Org\%C3\%A1nica\%20 del\%20Banco\%20Central.doc. >. Acesso em: 5 abril 2014.

Decreto $N^{\circ}$ 31730-MIDEPLAN-MIVAH. Programa de Regeneración y Repoblamiento de San José. Dado en la presidencia de la república. 3 fev. 2004.

CURY. Cury Construtora e Incorporadora S.A. Página Web de CURY. Disponível em: $<$ http://www.cury.net/ConhecaCury>. Acesso em: 4 nov. 2014.

CYRELA. Cyrela Brazil Reality | 50 anos de Cyrela. Comercial. Disponível em: $<$ http://www.cyrela.com.br/sobre/a-cyrela>. Acesso em: 4 nov. 2014.

DAL-SOTO, F.; ALVES, J. N.; BULÉ, A. E. Análise do processo de internacionalização do Modelo de Uppsala: caminhos para as empresas Brasileiras. Estudo \& Debate em Gestão \& Planejamento, v. 1, n. V. 21, p. 179-199, 2014. http://www.univates.br/ revistas/index.php/estudoedebate/article/view/977/589. Acesso em: 27 maio 2015.

DELGADO, É. Mutuales crearon un fondo de inversión que construye y vende viviendas. Disponível em: <http://www.elfinancierocr.com/finanzas/Mutual-Grupo MutualMucap-vivienda-fondo de inversion-desarrollo-hipotecas-titularizacion 0 389361085.html>. Acesso em: 7 jun. 2014. 
DELGADO, É. Alberto Ortuño. Disponível em: <http://www.elfinancierocr.com/negocios /Empresario del Ano 2013-Alberto Ortuno-GTU Desarrollos-Inversion-Distrito $4 \quad 0 \quad 42235$ 7786.html>. Acesso em: 7 abr. 2014.

DYSON, R. G. Strategic development and SWOT analysis at the University of Warwick. European Journal of Operational Research, v. 152, n. 3, p. 631-640, 1 fev. 2004.

DUNNING, J. Toward an eclectic theory of international production: some empirical tests. Journal of International Business Studies, v. 11, n. 1, p. 9-31, 1980.

EZTEC. ECTEC Construindo qualidade de vida. Página Web de EZTEC. Disponível em: <http://www.eztec.com.br/imoveis/A-EZTEC>. Acesso em: 6 nov. 2014.

FÉ, A. L. Depois das parcerias. Construção Mercado, n. 113-Agosto, p. 2, 2012. Disponível em:<http://revista.construcaomercado.com.br/negocios-incorporacao-construcao/133/ artigo263498-1.asp > Acesso em: 22 maio 2013.

FERNÁNDEZ, E. F. Plan de negocios y plan estratégico para la diversificación de la empresa Constructora BAUER Internacional S.A. 2011. Proyecto Final - MDI XXIV, (Master en Dirección de Empresas Constructoras e Inmobiliarias) - Escuela Técnica Superior de Arquitectura, Departamento de Construcción y Tecnología Arquitectónicas, Universidad Politécnica de Madrid, Madrid, 2011.

FLORENTINO, M. S.; GOMES, J. S. Controle Gerencial em Empresas Brasileiras Internacionalizadas do Setor de Serviços - O CASO DA SPOLETO. Contabilidade, Gestão e Governança, v. 12, n. 2, 2009.

FUNDAÇÃO PROMOTORA DE MORADIA. Informe Nacional de Vivienda: Situación de Vivienda y Desarrollo Urbano en Costa Rica 2010. Costa Rica: Fundación Promotora de Vivienda, 2011. 86p.

Informe Nacional de Vivienda: Situación de Vivienda y Desarrollo Urbano en Costa Rica 2011. Costa Rica: Fundación Promotora de Vivienda, 2012. 103p.

Informe Nacional de Vivienda: Situación de Vivienda y Desarrollo Urbano en Costa Rica 2012. Costa Rica: Fundación Promotora de Vivienda, 2013. 145p.

GIBLER, K. M.; BLACK, R. T.; MOON, K. P. Time, Place, Space, Technology and Corporate Real Estate Strategy. Journal of Real Estate Research, v. 24, n. 3, p. 235-262, 2002. Disponível em: <http://ideas.repec.org/a/jre/issued/v24n32002p235-262.html>. Acceso em: 11 de mar. 2014.

GLOBAL DEMOCRACY RANKING. Global Democracy Ranking - Ranking. Disponível em: <http://democracyranking.org/?page id=14>. Acesso em: 27 mar. 2014.

HILAL, A.; HEMAIS, C. A. O processo de internacionalização na ótica da escola nórdica: evidências empíricas em empresas brasileiras. Revista de Administração Contemporânea, v. 7, n. 1, p. 109-124, 2003. Disponível em: <http://www. scielo.br/scielo.php?pid=S1415-65552003000100006\&script=sci arttext \&tlng=es $>$. Acceso em: 14 mai. 2013.

HYMER, S. The internationalization of capital. Journal of Economic Issues, v. 6, n. 1, p. 91-111, 1972.

INSTITUTO DE FOMENTO E ACONSELHAMENTO MUNICIPAL. Regiones y Cantones de Costa Rica. Costa Rica: Instituto de Fomento y Asesoría Municipal, 2003. 
INSTITUTO NACIONAL DE ESTATÍSTICA E CENSO. INEC Costa Rica. Disponível em: <http://www.inec.go.crW eb/Home/pagPrincipal.aspx>. Acesso em: 10 fev. 2013.

Resultados e séries, vivienda. Disponível em: $<$ http://www.inec.go.cr/enaho/result /vivienda.aspx>. Acesso em: 16 mar. 2013.

Estadística de la Construcción, Publicaciones. Disponível em: <http://www.inec.go.crWeb/Home/GeneradorPagina.aspx>. Acesso em: 10 maio. 2013.

Encuesta Nacional de Hogares Julio 2013: Resultados generales: ISSN: 22153381. San José, Costa Rica: Instituto Nacional de Estadística e Censo, 2013.

INTERNACIONAL FINANCE CORPORATION. Facilidad para hacer negocios en Costa Rica. DOING BUSINESS. Disponível em: <http://espanol.doingbusiness.org /data/exploreeconomies/costa-rica>. Acesso em: 4 fev. 2014.

JAVERNICK-WILL, A. N. Organizational learning during internationalization: acquiring local institutional knowledge. Construction Management and Economics, v. 27, n. 8, p. 783-797, 1 ago. 2009.

JAVIDAN, M. Core competence: What does it mean in practice? Long Range Planning, v. 31 , n. 1, p. 60-71, fev. 1998.

JOHANSON, J.; VAHLNE, J. The internationalization process of the firm - A model of knowledge development and increasing foreign market commitments. Journal of International Business Studies, v. 8, n. 1, p. 23-32, 1977.

JOHANSON, J.; WIEDERSHEIM-PAUL, F. The internationalization of the firm: four Swedish cases. Journal of Management Studies, v. 12, n. 3, p. 305-322, 1975.

JUNG, W. et al. Empirical assessment of internationalization strategies for small and medium construction companies. Journal of Construction Engineering and Management, v. 136, n. 12, p. 1306-1316, 2010.

KINDLEBERGER, C.P. American Business Abroad. Yale University Press - New Haven United State, 1969.

KOJIMA, K. Macroeconomics versus international business approach to foreign Direct investment. Hitosubashi Journal of Economics, v. 23, p. 630-640, 1982.

KOTLER, P. Marketing Management. 10th. ed. New Jersey: Prentice Hall, 2000.

KOTLER, P.; KELLER K. Administração de marketing. Tradução de Mônica Rosenberg, Brasil Ramos Fernandes, Cláudio Freire. 12 ed. São Paulo: Pearson Prentince Hall, 2006.

LEITÓN, P. Inflación del 2013 fue de 3,68\% Disponível em: $<$ http://www.nacion.com/economia/indicadores/INEC-inflacion-bccr 0 1388261232.html>.

Acesso em: 27 mar. 2014.

LINJIE, C. Research on the Core Competencies Identification and Evaluation of Real Estate Enterprise. In: 2011 INTERNATIONAL CONFERENCE ON E-BUSINESS AND EGOVERNMENT (ICEE2011) - Proceedings. Anais..., 2011. 5p.

LIU, B.; CHEN, S. The application of innovation SWOT theory to strategic-making for Chinese international contractors. In: 2012 INTERNATIONAL CONFERENCE ON 
INFORMATION MANAGEMENT, INNOVATION MANAGEMENT AND INDUSTRIAL ENGINEERING (ICIII2012). Anais..., 2012.

LORD, M. D.; RANFT, A. L. Organizational Learning About New International Markets: Exploring the Internal Transfer of Local Market Knowledge. Journal of International Business Studies, v. 31, n. 4, p. 573-589, 1 dez. 2000.

LU, W. Improved SWOT approach for conducting strategic planning in the construction industry. Journal of Construction Engineering and Management, v. 136, n. 12, p. 13171328, 2010.

MANNING, C.; EPLEY D. Do Real Estate Faculty Teach the Skills and Competencies Needed by Corporate Real Estate Executives? 2006. Disponível em: $<$ http://www.researchgate.net/publication/228370556 Do Real Estate Faculty

Teach the Skills and Competencies Needed by Corporate Real Estate Executives $>$.

Acceso em: 11 mar. 2013.

MINISTÉRIO DE ECONOMIA, INDÚSTRIA E COMERCIO. Política Nacional de Ordenamiento Territorial 2012 a 2040 Contextualización y Línea Base. Costa Rica: Ministerio de Vivienda y Asentamientos Humanos, 83 p., 2012a.

Propuesta de Plan de Ordenamiento Territorial de la Gran Área Metropolitana 2011-2030. Costa Rica: Ministerio de Vivienda y Asentamientos Humanos, 146 p., 2012b. Disponível em: < http://www.mivah.go.cr/POTGAM.shtml>. Acceso em: 13 de nov. de 2013

Informe sobre los prográmas de crédito dirigidos a vivienda: Principales características y condiciones vigentes en el Sistema Financiero Nacional al año 2013. Costa Rica: Ministerio de Moradia e Asentamentos Humanos, 20 p., 2013a.

Política Nacional de Ordenamiento Territorial 2012-2040. Costa Rica: Ministerio de Vivienda y Asentamientos Humanos, 45 p., 2013b.

Política Nacional de Vivienda y Asentamientos Humanos 2013 a 2030 y Plan de Acción. San José: Ministerio de Vivienda y Asentamientos Humanos, 83 p., 2013c.

MONETTI, E. Demandas de Conhecimento nas Incorporadoras. Texto para Coluna do NRE-POLI na Revista Construção e Mercado - Pini - Fevereiro 2009, p. 7, 2009.

NUMMELA, N.; SAARENKETO, S.; PUUMALAINEN, K. A Global Mindset - A Prerequisite for Successful Internationalization? Canadian Journal of Administrative Sciences / Revue Canadienne des Sciences de l'Administration, v. 21, n. 1, p. 51-64, 2004.

OSLAND, G. E.; TAYLOR, C. R.; ZOU, S. Selecting international modes of entry and expansion. Marketing Intelligence \& Planning, v. 19, n. 3, p. 153-161, 1 jun. 2001.

PAIM, C. da F. Competências e Internacionalização. Revista Negócios e Talentos. Porto Alegre, n.6, p 113-131, 2009.

PENROSE, E. A teoria do Crescimento da Firma. Campinas - SP - Brasil: Editorial da Unicamp, 1995.

PICKTON, D. W.; WRIGHT, S. What's swot in strategic analysis? Strategic Change, v. 7, n. 2, p. 101-109, 1998. 
PORTER, M. E. The Competitive Advantage of Nations. Harvard Business Review. 1990. Disponível em: https://hbr.org/1990/03/the-competitive-advantage-of-nations Acceso em: 07 de dez. de 2014.

PRAHALAD, C. K.; HAMEL, G. Estratégia Corporativa e Escopo Empresarial: 3. Competência Essencial da Corporação. Rio de Janeiro: Campus, 1998.

PRANGE, C.; VERDIER, S. Dynamic capabilities, internationalization processes and performance. Journal of World Business, Africa Special Issue Section. v. 46, n. 1, p. 126133, 2011.

PROGRAMA ESTADO DA NAÇÃO. Decimoctavo Informe Estado de la Nación en Desarrollo Humano Sostenible. San José: Programa Estado de la Nación (PEN), 2012.

Decimonoveno Informe Estado de la Nación en Desarrollo Humano Sostenible. San José: Programa Estado de la Nación (PEN), 2013. Disponível em: <http://www.estadonacion.or.cr/estado-nacion/informe-actual>. Acesso em: 1 fev. 2014.

ROCHA LIMA, J. da J. Política empresarial e diretrizes de ação. Boletim Técnico. BT/PCC/126. Escola Politécnica da Universidade de São Paulo. 1994. Disponível em: <http://publicacoes.pcc.usp.br/PDFs\%20novos/BTs/BT-126.pdf>. Acesso em: 13 maio 2013.

Começar de Novo. Performance adiante das empresas de real estate de capital aberto no Brasil. In: CONGRESSO LARES 2012. Anais..., São Paulo, Brasil. 2012.

ROCHA LIMA, J. DA J.; ALENCAR, C. T. Foreign investment and the Brazilian real estate market. International Journal of Strategic Property Management, v. 12, n. 2, p. 109-123, 1 abr. 2008.

ROCONTEC. Rocha Construção e Tecnología. Página Web de Rocontec. Disponível em: <http://www.rocontec.com.br/companhia>. Acesso em: 16 nov. 2014.

RODRÍGUEZ, A. V. Banco Nacional lanza nuevo fondo de inversión que permitirá alquilar una vivienda y optar por su compra. Disponível em: <http://www. elfinancierocr.com/finanzas/Banco-Nacional-inversion-permitira-alquilar_0_401359872.

html>. Acesso em: 7 jun. 2014.

RRG. RRG Construtora. Página Web de RRG. Disponível em: <http://www.rrg.com.br/institucional/empresa/>. Acesso em: 16 nov. 2014.

SÁNCHEZ, I. G. La formación de la estrategia de selección de mercados exteriores en el proceso de internacionalización de las empresas. Tesis doctoral - Universidad de Las Palmas de Gran Canaria, Facultad de Ciencias Económicas y Empresariales, España, 2003. 318 p. Disponible en: <http://www.eumed.net/tesis-doctorales/igs/>. Acceso en: 27 mayo 2015.

SOTO, E. Bandas cambiarias cumplen siete años en Costa Rica. Periódico digital. Disponível em: <http://www.elfinancierocr.com/ELFINF20131008_0001/index.html>. Acesso em: 13 nov. 2013.

SCHERER, F. L.; GOMES, C. M.; KRUGLIANSKAS, I. The internationalization process of brazilian companies: a study of multiple cases in the heavy construction industry. BAR Brazilian Administration Review, v. 6, n. 4, p. 280-298, dez. 2009.

SOUZA, F. F. de A. Análise das influências das estratégias de diversificação e dos modelos de negócios no desempenho das empresas de real estate no período 2005 a 
2010. 2011. 187 p. Dissertação (Mestrado em Engenharia de Construção Civil e Urbana) Escola Politécnica: Universidade de São Paulo, São Paulo, 2011.

SUPERINTENDÊNCIA GERAL DE ENTIDADES FINANCEIRAS. Acuerdo SUGEF 23-00. Normas para establecer la suficiencia patrimonial de las entidades fiscalizadas por la superintendencia general de entidades financieras. 2001. Disponível em: <http://www.sugef.fi.cr/servicios/documentos/normativa/normativaprudencial/Sugef-10.html> Acceso em: 07 maio 2014.

Acuerdo SUGEF 5-04. Reglamento sobre límites de crédito a personas individuales y grupos de interés económico. 2004. Disponível em: <http://www.sugef.fi.cr/servicios/ documentos/Normativa/normativaprudencial/Reglamento\%205-04/SUGEF\%2005-04.pdf> Acceso em: 07 maio 2014.

URBAN, T. P.; FLEURY, M. T. L. Competências e Internacionalização: Um estudo de caso em empresa brasileira com subsidiária de produção no exterior. In: SEMINÁRIO EM ADMINISTRAÇÃO FEA-USP. FEA-USP: 2005.

VARGAS, N. Organizações em ambientes internacionais turbulentos: estudo de uma construtora multinacional brasileira. 2008. 161 p. Tese (Doutorado em Engenharia de Produção) - Escola Politécnica, Universidade de São Paulo, São Paulo, 2008. Disponível em: < http://www.teses.usp.br/teses/disponiveis/3/3136/tde-01102008-135351>. Acceso em: 10 mar. 2014.

VBI REAL ESTATE. VBI Real Estate. Página Web de VBI Real Estate. Disponível em: $<$ http://www.vbirealestate.com/site/home-pt>. Acesso em: 4 nov. 2014.

VERNON, R. International investment and international trade in the product cycle. Quarterly Journal of Economics, v. 80, n. 2, p. 190-207, 1966.

VINDAS, L. Infraestructura sigue bloqueando la competitividad de Costa Rica Resultados del Informe de Competitividad Global 2010-2011. Periódico digital. Disponível em: <http://wvw.elfinancierocr.com/ef archivo/2010/septiembre/12/economia 2515808.html >. Acesso em: 8 nov. 2013.

WEFORUM. The Global Competitiveness Index 2013-2014 - World Economic Forum. Disponível em: <http://widgets2.weforum.org>. Acesso em: 30 nov. 2013.

ZAPLETALOVA, S. The internationalization process of Czech companies. International Business Management, v. 8, n. 6, p. 361-368, 2014. 


\title{
8. APÊNDICES
}

\subsection{APENDICE A - Documento para a entrevista às empresas de real estate residencial}

\section{ANÁLISE SWOT DAS EMPRESAS BRASILEIRAS DE REAL ESTATE VISANDO O MERCADO DA COSTA RICA}

\section{Parte 1. Informação geral da entrevista}

\author{
Nome da empresa: \\ Nome do entrevistado: \\ Cargo: \\ Data: \\ Local: \\ Sitio Web:
}

Em breve, será apresentado um conjunto de informações que descreve o ambiente de negócios e as características do mercado residencial da Costa Rica, com o objetivo de reconhecer os elementos que motivariam ou afastariam às empresas brasileiras de real estate residencial a entrar neste mercado.

Analisaram-se as principais conjunturas econômicas, político-legais e socioculturais da Costa Rica, e as características intrínsecas de seu mercado residencial, tais como: demanda potencial, características das linhas de crédito, nível da oferta máxima e ação da concorrência. A informação foi sintetizada e dividida primeiramente em oportunidades e ameaças de mercado, e esta subdividida segundo seu nível de impacto para o desempenho dos negócios das empresas de real estate residencial em: baixo, médio e alto (parte 2 da entrevista).

Após da análise desta informação, o entrevistado terá que tomar uma decisão sobre o interesse da empresa no mercado costarriquenho (parte 3 da entrevista), e responder uma serie de perguntas que justificam esta decisão, com base nas oportunidades e ameaças deste mercado, e as características próprias da companhia (parte 4 da entrevista). 
Parte 2. Ambiente de negócios e características do mercado residencial da Costa Rica

\subsection{Oportunidades de mercado da Costa Rica}

Baixo impacto

As oportunidades de baixo impacto para as empresas de real estate residencial no mercado costarriquenho são provenientes das cojunturas econômicas, político-legais e socioculturais do país, caracterizadas, a seguir:

- Economia com inflação estável nos últimos cinco anos, ficando o Índice de Preços ao Consumidor (IPC) dentro das metas de inflação da atual política monetária: entre 4-6\%.

- Importante e crescente Investimento Estrangeiro Direto (IED), nos últimos anos, na economia local. Em 2013 este investimento foi de 2.714,2 milhões de dólares. As atividades imobiliárias em 2012 representaram 19\%, e em 2013 ao redor de $43 \%$.

- Alta estabilidade política e transparência institucional do país.

- O governo promove políticas de competitividade, nos temas de: regulações, alvarás de construção, infraestrutura, financiamento, investimento local, eficiência governamental, IED, desenvolvimento do capital humano e inovação.

- Simplificação e diminuição do tempo para obter alvarás de construção e outras formalidades nas instituições públicas.

- Atualização da legislação urbanística e uso da internet nos processos governamentais.

- Alto nível educacional, recursos humanos especializados e centros de pesquisas e desenvolvimento.

- Localização estratégica para entrada no mercado norte-americano e em outros blocos econômicos importantes.

- Concentração da maior parte da população e das atividades na região central do país, o que favorece a concentração das atividades das empresas residenciais em determinada área.

- Na Costa Rica o Sistema Financeiro Nacional é um sistema formal, estruturado e regulado. 
2.2. Oportunidades de mercado da Costa Rica

Médio impacto

As oportunidades de médio impacto correspondem principalmente àquelas conjunturas político-legais que promovem os assentamentos humanos e o ordenamento territorial como:

- Políticas para incentivar as Parcerias Público-Privadas (PPP), operações urbanas e uso do solo, nos principais centros urbanos. Com preferência aos projetos residenciais de alta densidade, que interatuem com o entorno da cidade e médio ambiente. Especialmente aqueles investimentos que favoreçam a renovação urbana do centro da capital (região mais populosa), facilitando os créditos para estas empresas e a obtenção de alvarás de construção.

- Criação de políticas de incentivo direto na gestão dos projetos residenciais, com exoneração do pago das taxas de construção nas prefeituras e aumento dos Coeficientes de Aproveitamento do Solo, em projetos residenciais de alta densidade e sustentáveis com o meio ambiente.

- Incentivos ao acesso de moradia à classe média, com auxílio, especialmente, na entrada da compra do imóvel com alguma espécie de subsídio.

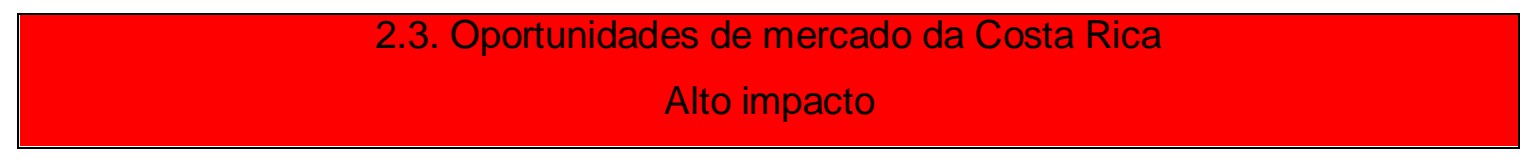

As oportunidades de alto impacto a serem aproveitadas pelas empresas de real estate são, diretamente, obtidas da análise do mercado residencial costarriquenho. Elas são:

1. Mais de dois quintos da população encontra-se dentro dos lares com poder aquisitivo importante; com rendas médias: acima de 4 salários mínimos (US\$ 1575,6), e rendas altas: acima de 10 salários mínimos (US\$3939,0). Ver a Tabela 1 com segmentação dos lares costarriquenhos. 
Tabela 1. Segmentos de renda segundo ENAHO 2013

\begin{tabular}{cccccccc}
\hline & \multicolumn{5}{c|}{ Quintil de renda per capita } & \\
\hline Características & Total & I & II & III & IV & V \\
Total de pessoas & 4.709 .161 & 1.049 .166 & 1.035 .489 & 979.532 & 859.826 & 785.148 \\
Total de lares & 1.376 .000 & 275.526 & 274.839 & 275.202 & 275.179 & 275.254 \\
$\begin{array}{c}\text { Renda média por lar } \\
\text { (US\$) }\end{array}$ & $1.942,9$ & 390,4 & 865,2 & $1.338,9$ & $2.062,5$ & $5.057,3$ \\
$\begin{array}{c}\text { Renda per capita por lar } \\
\text { (US\$) }\end{array}$ & 652,1 & 102,5 & 230,0 & 377,2 & 663,2 & $1.887,5$ \\
\hline & Fonte: Instituto Nacional de Estatística e Censo (2013) & &
\end{tabular}

2. A carência residencial do país, segundo os índices para sua definição ${ }^{30}$, encontra-se na faixa de 184 mil a 670 mil unidades. Somente considerando as famílias que alugam mais as que moram em imóveis em mau estado, estas sumam 383 mil unidades habitacionais, sendo o estoque residencial aproximadamente $16 \%$ deste valor.

3. Nos últimos anos registra-se o crescimento anual das famílias costarriquenhas em 2,64\%, estas conformadas em sua maioria de 3 a 4 membros. Segundo projeções do Ministério de Moradia e Assentamentos Humanos (MIVAH), a área metropolitana necessitará de 250.000 novas moradias em 2030 para seus 825.000 novos habitantes.

Tabela 2. Dados dos habitantes da Costa Rica segundo os Censos de 1984, 2000 e 2011

\begin{tabular}{cccc}
\hline Ano & Habitantes & Lar & $\begin{array}{c}\text { Média } \\
\text { Habitantes/Lar }\end{array}$ \\
\hline $\mathbf{1 9 8 4}$ & 2.416 .809 & 513.431 & 4,7 \\
$\mathbf{2 0 0 0}$ & 3.810 .179 & 960.098 & 4,0 \\
$\mathbf{2 0 1 1}$ & 4.301 .712 & 1.238 .438 & 3,5 \\
\hline
\end{tabular}

Fonte: (FUNDAÇÃ̃ PROMOTORA DE MORADIA 2012), p. 34) dados com Censos da Costa Rica

4. O sistema bancário possui diversas alternativas para que o público opte por financiamento de moradia própria. No caso das empresas, estas podem financiar seus projetos com um empréstimo para empresa ou estruturar um financiamento por médio da securitização da dívida ou fundos de investimento imobiliário.

\footnotetext{
${ }^{30}$ Déficit Habitacional Tradicional: $\mathrm{DHT}=\mathrm{FN}+\mathrm{DQT}(\mathrm{M}+\mathrm{Rs}+\mathrm{Bs})$

Déficit Habitacional Real: $\mathrm{DHR}=\mathrm{FN}+\mathrm{DQR}(\mathrm{M}+\mathrm{R}+\mathrm{BR}+\mathrm{Bs})$
} 
5. Além disso, as taxas de juros de referencia e para o setor imobiliário, até o momento, apresentam valores baixos em relação aos registros históricos (ver Figura 1 e 2).

Figura 1. Média anual das taxas de referência para juros no Brasil e na Costa Rica, período de 2002-2013

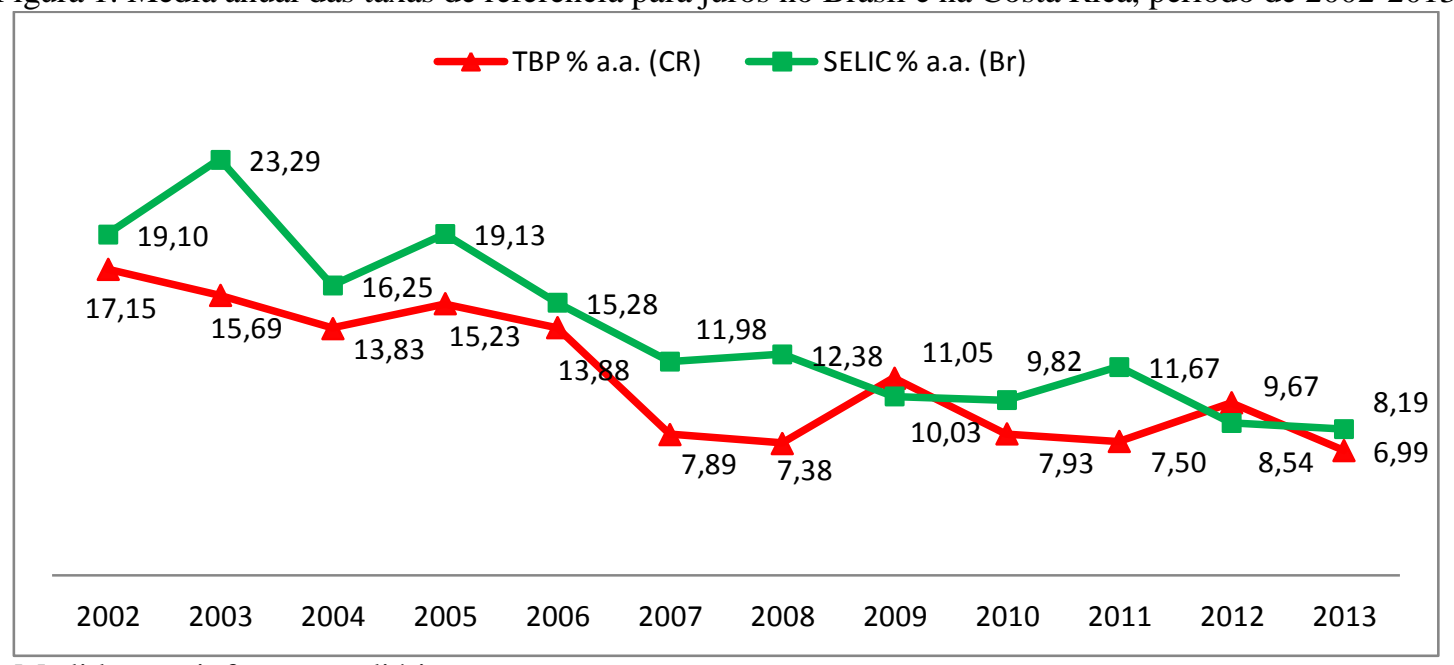

Nota:Medida com informação diária.

Fonte: Elaborado pelo autor com dados Banco Central da Costa Rica (BCCR) e Banco Central do Brasil (BCB)

Figura 2. Taxas de juros para financiamento imobiliário Costa Rica e Brasil

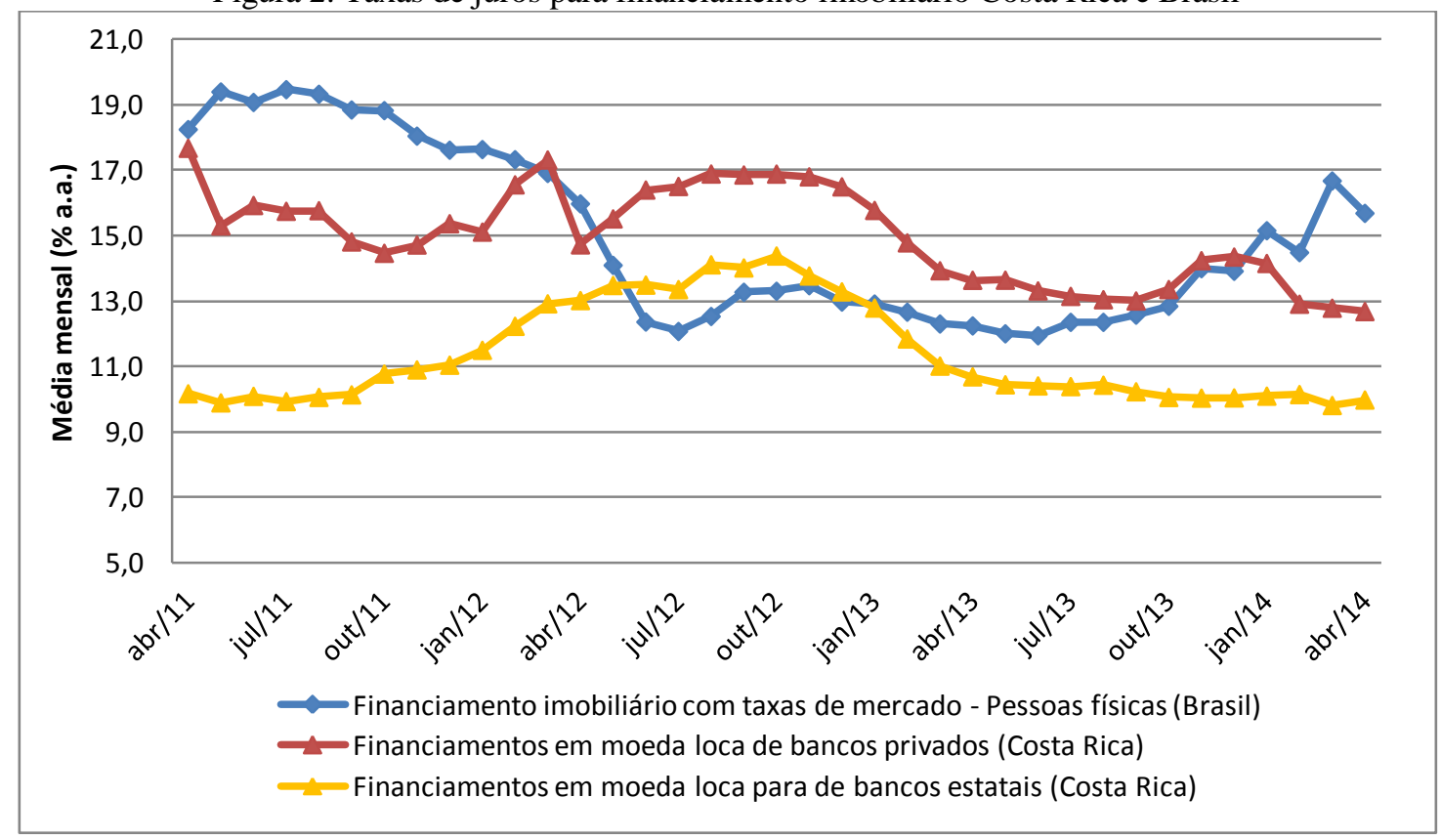

Fonte: Elaborado pelo autor com dados BCCR e BCB

6. O mercado residencial mostra mudanças nas tendências de moradia, com aumento progressivo nos últimos anos dos metros quadrados tramitados para apartamentos e condomínios (ver Figura 3). 
Figura 3. Metros quadrados aprovados em permissões de construção

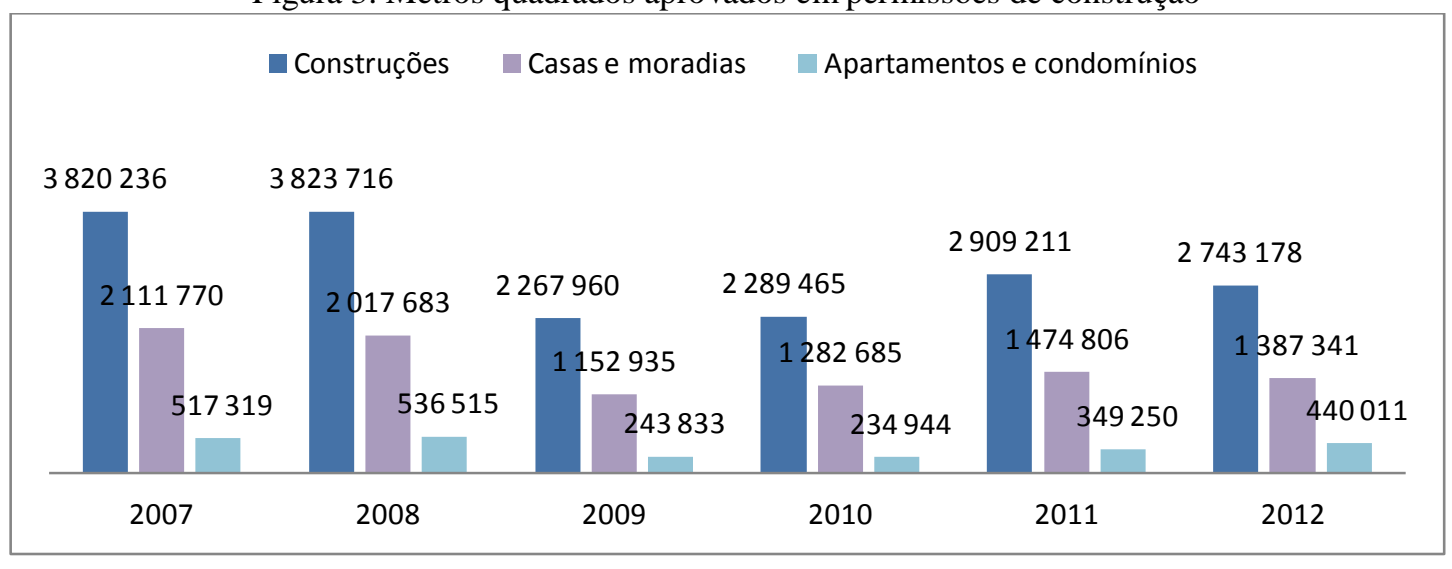

Fonte: Elaborado pelo autor com dados INEC

7. Os níveis de renda médios e baixos não são atendidos pela concorrência local, focalizando os grandes projetos às classes média-alta e alta.

Tabela 3. Ação da concorrência na GAM

\begin{tabular}{ccccccc}
\hline $\begin{array}{c}\text { Preço aprox. da solução } \\
\text { habitacional (Mil) }\end{array}$ & Projetos & $\begin{array}{c}\text { Unidades } \\
\text { habitacionais }\end{array}$ & $\begin{array}{c}\text { Média de } \\
\text { unid. hab. } \\
\text { por projeto }\end{array}$ & $\begin{array}{c}\text { Área média da } \\
\text { unid. (m2) }\end{array}$ \\
\hline < de U\$100 & 8 & $10,1 \%$ & 1140 & $14,8 \%$ & 143 & 115 \\
\hline Entre US\$100 e US\$200 & 49 & $\mathbf{6 2 , 0 \%}$ & 4945 & $\mathbf{6 4 , 0 \%}$ & 101 & 123 \\
\hline > de U\$ 200 & 11 & $13,9 \%$ & 833 & $10,8 \%$ & 76 & 206 \\
N/D & 11 & $13,9 \%$ & 806 & $10,4 \%$ & 73 & 152 \\
Total & 79 & $100,0 \%$ & 7724 & $100,0 \%$ & 98 & \\
\hline
\end{tabular}

Fonte: FUPROVI (2013)

Figura 4. Densidade de projetos por número de dormitórios

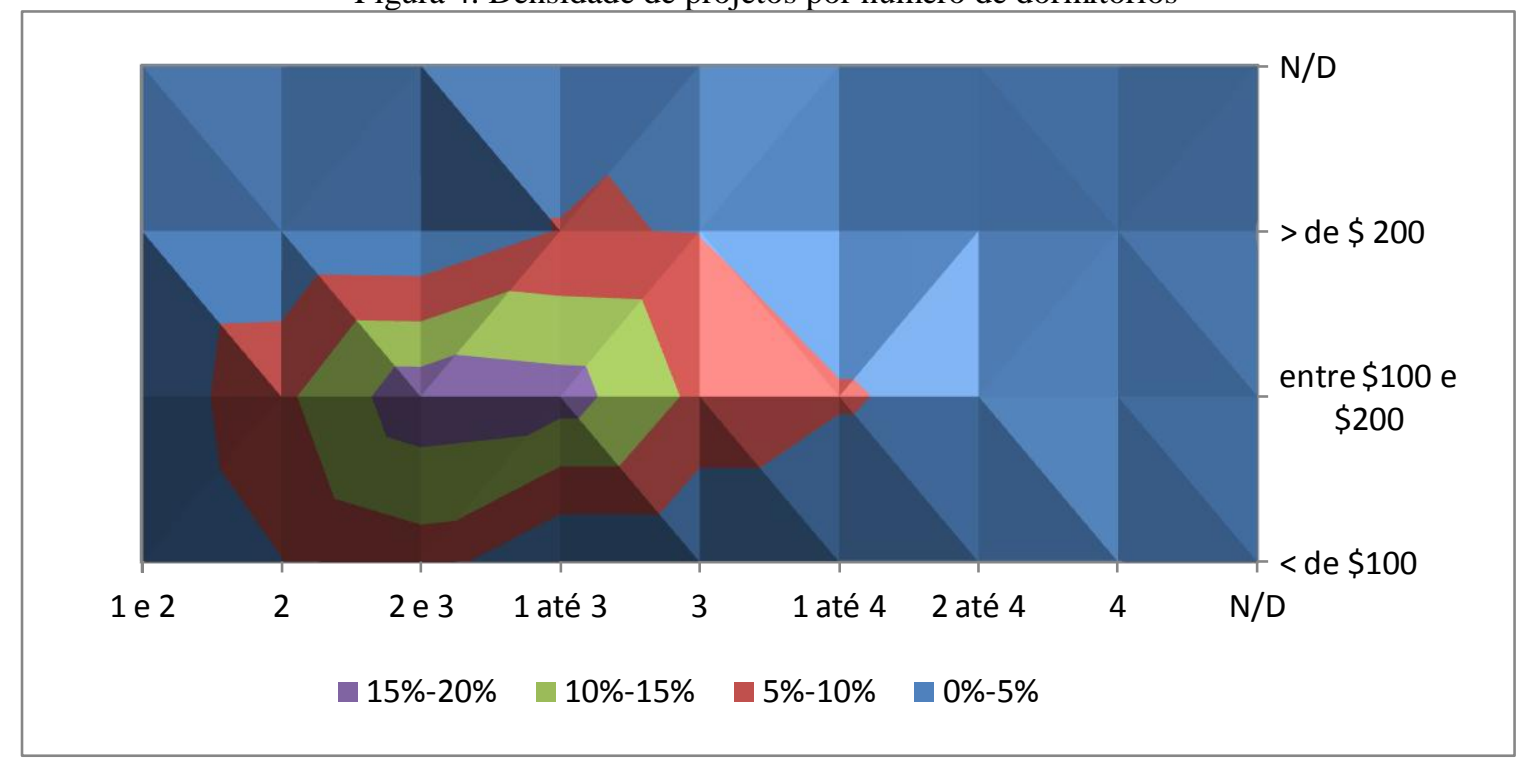

Fonte: FUPROVI (2013) 


\subsection{Ameaças de mercado da Costa Rica}

Baixo impacto

As ameaças de baixo impacto para as empresas de real estate residencial no mercado costarriquenho em sua maioria vêm das cojunturas econômicas, políticolegais e socioculturais do país, caracterizadas, a seguir:

- O país possui uma economia susceptível aos acontecimentos globais, com dependência dos mercados norte-americanos e europeus. Além disso, ele está em processo de recuperação após Crise Mundial de 2008; ainda sem uma estabilidade consolidada ante as incertezas e ações dos mercados internacionais (ver Figura 5).

- O país tem mostrado aumento da dívida do setor público nos últimos anos. Esse aumento poderia afetar a sustentabilidade e solvência econômica nacional, influindo nas taxas de juros e inflação para a alta.

- Não são apresentadas melhorias nos referentes sociais, com indicadores como desemprego e desigualdade em aumento nos últimos anos.

- Legislação urbana deficiente, desatualizada e com pouca abrangência no território local.

- Apresentam-se gargalos de competitividade ligados à deterioração e atraso da infraestrutura rodoviária, portuária e aeroportuária. Além de entraves legais e burocráticos nos processos produtivos, e baixa proteção ao inversor minoritário em sociedades anônimas.

- O país possui alto risco aos fenômenos naturais: 36,8\% da superfície continental do país está exposta a três ou mais fenômenos naturais.

Figura 5. Variação percentual da economia e setor construção, período 2007-2014

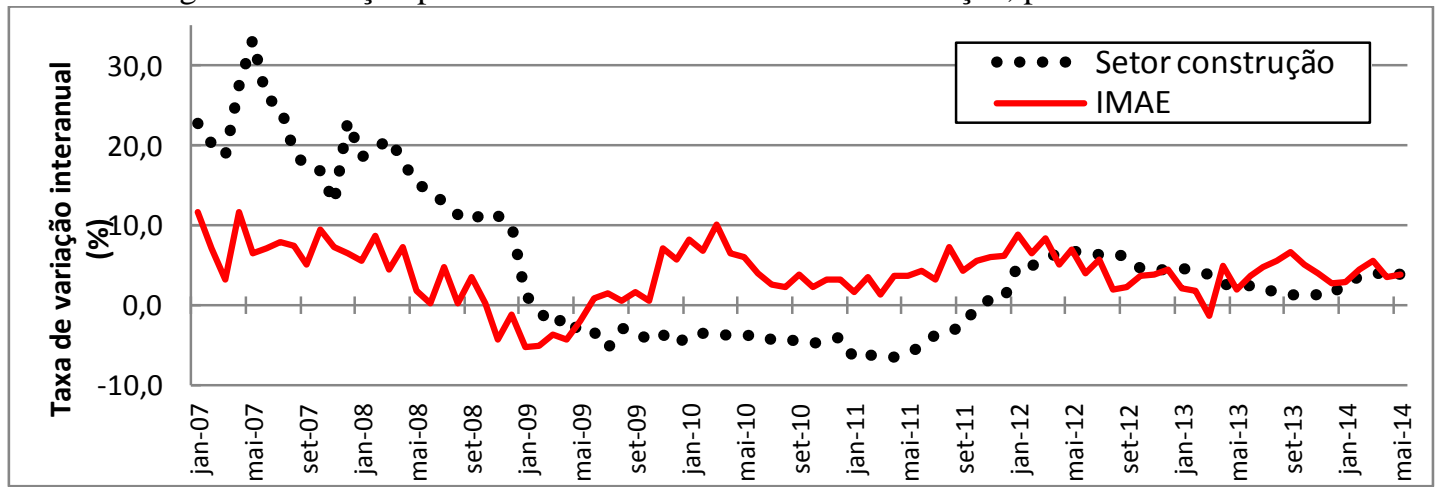

(*) Ano 1991=100

Fonte: Elaborado pelo autor com dados BCCR, Departamento de Estadística Macroeconômica 


\subsection{Ameaças de mercado da Costa Rica}

Médio impacto

As ameaças de médio impacto para projetos residenciais correspondem principalmente às provenientes do Sistema Financeiro Nacional (SFN). Elas são descritas, a seguir:

- O sistema financeiro costarriquenho não possui nenhuma diretriz da quantidade dos recursos que os bancos devem destinar ao setor residencial. Cabe ao próprio banco estabelecer suas políticas creditícias e destinar seus fundos a determinado produto ou linha de financiamento, exemplo: compra de moradia própria.

- As instituições financeiras podem investir em uma empresa ou grupo de interesse econômico o montante máximo de $20 \%$ de seu patrimônio, ou menos, a depender das políticas internas dos bancos.

- Ainda que a Costa Rica possua políticas de bandas cambiarias, com tetos e chão fixos, em curto prazo de tempo, podem ocorrer mudanças abruptas do câmbio da moeda local frente ao dólar por condições exógenas (ver figura 6). Isto se reflete na aquisição e no pagamento dos créditos aplicados em dólares para moradia, principalmente, porque eles foram muito procurados devido às baixas taxas de juros comparadas aos créditos em moeda local, mesmo que a maioria das rendas das famílias costarriquenhas esteja na moeda local.

Cerca de $50 \%$ dos créditos colocados a pessoas e empresas pela banca costarriquenha são em dólares. Estas mudanças no regime de câmbio diminuiriam a força de crescimento do crédito para os próximos anos.

Figura 6. Regime de câmbio 2013-2014

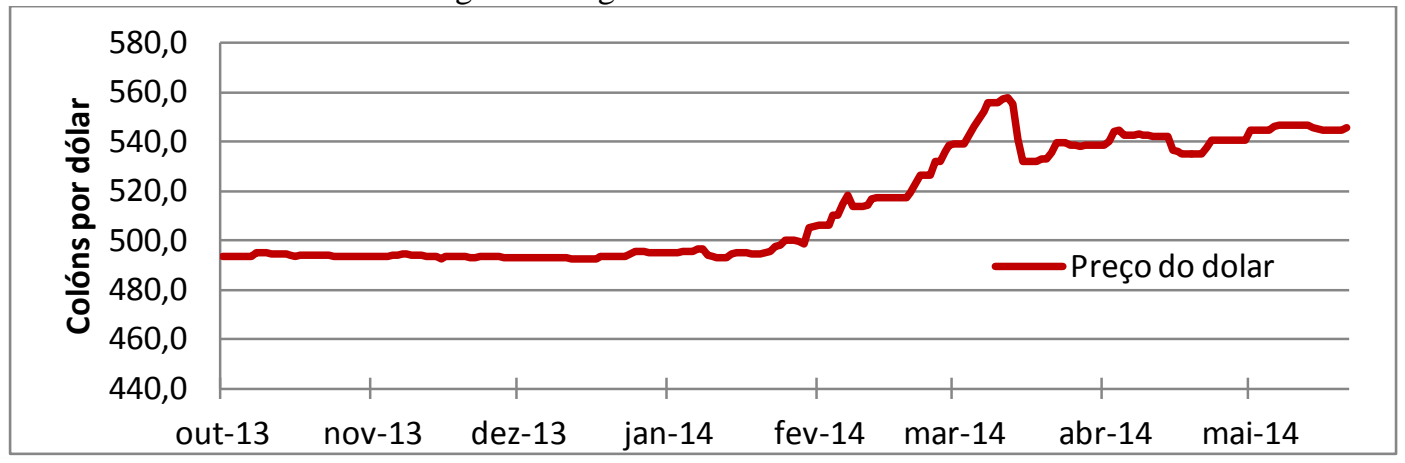

Fonte: Autor com dados do BCCR 


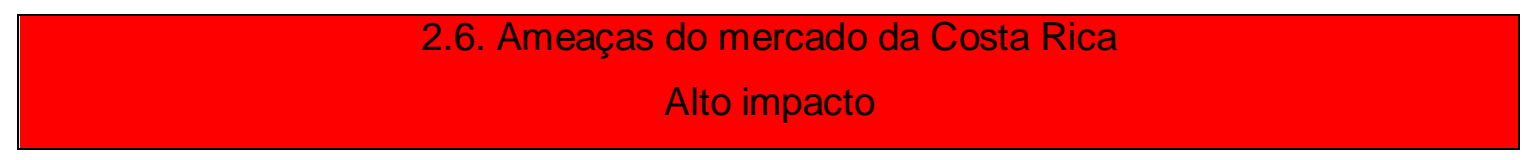

As ameaças de alto impacto a ser consideradas pelas empresas de real estate são aquelas obtidas diretamente da análise do mercado residencial costarriquenho. Estas são:

1. O tamanho deste, pois o país possui 4,7 milhões de habitantes, atualmente. Espera-se um crescimento de $39 \%$ até fim de século, para um total de 6,0 milhões de habitantes. Além disso, a cultura instalada no país é morar em casas e há pouca representatividade de morar em prédios (ver Figura 7).

Figura 7. Percentagem de moradias ocupadas, período 2010-2013 ENAHO (só região urbana)

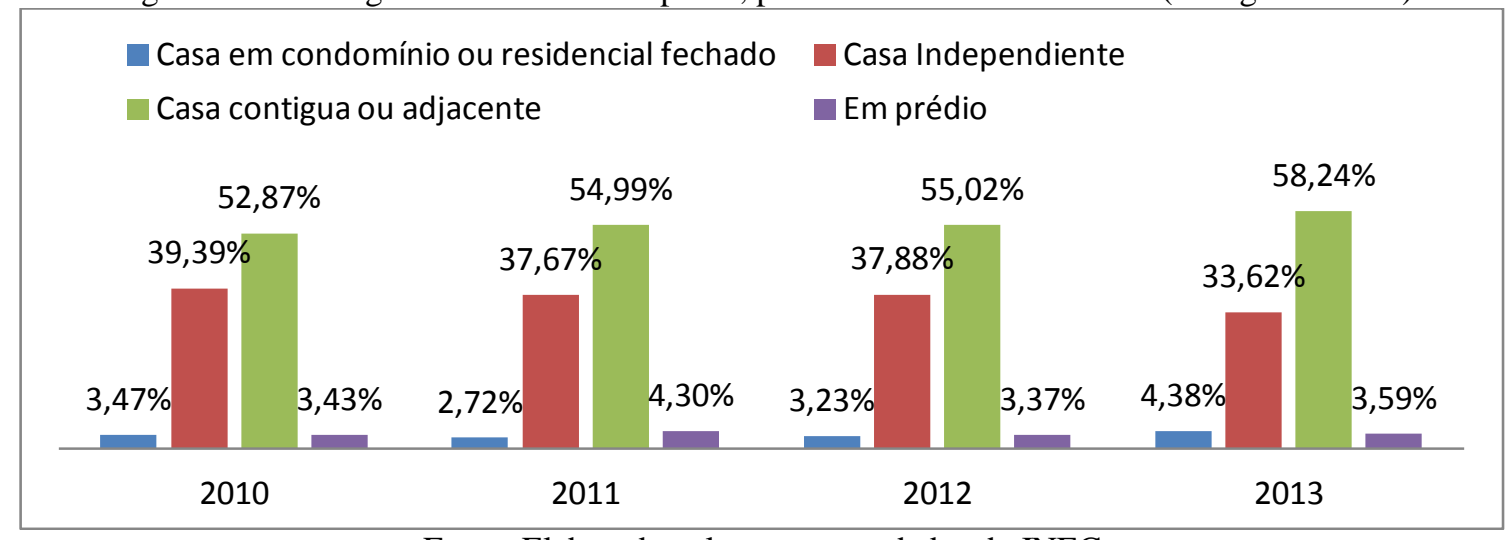

Fonte: Elaborado pelo autor com dados do INEC

2. O sistema financeiro apresenta duas ameaças: [i] para as empresas, a quantidade de requisitos solicitados pelos bancos para um financiamento e a complexidade e tempo que demora a obtenção dos alvarás de construção, ocasionam que os bancos redirecionarem seus recursos a outros projetos. [ii] Para o público, a dinâmica dos sistemas de financiamento pode desmotivar a aquisição de empréstimo para moradia, por causa do número de requisitos, tempo de aprovação, custos de formalização e estruturação das taxas de juros. Suma-se a esta ameaça, a pouca poupança acumulada ou carência de cultura de poupança pelas famílias costarriquenhas.

3. O comportamento dos bancos mais cauteloso após a Crise de 2008, acarreou a diminuição de recursos destinados a moradia, mostrando leves aumentos segundo os resultados e recuperação da economia local. 
Figura 8. Colocação anual total de créditos para moradia no SFN em dólares e número de moradias com alvará

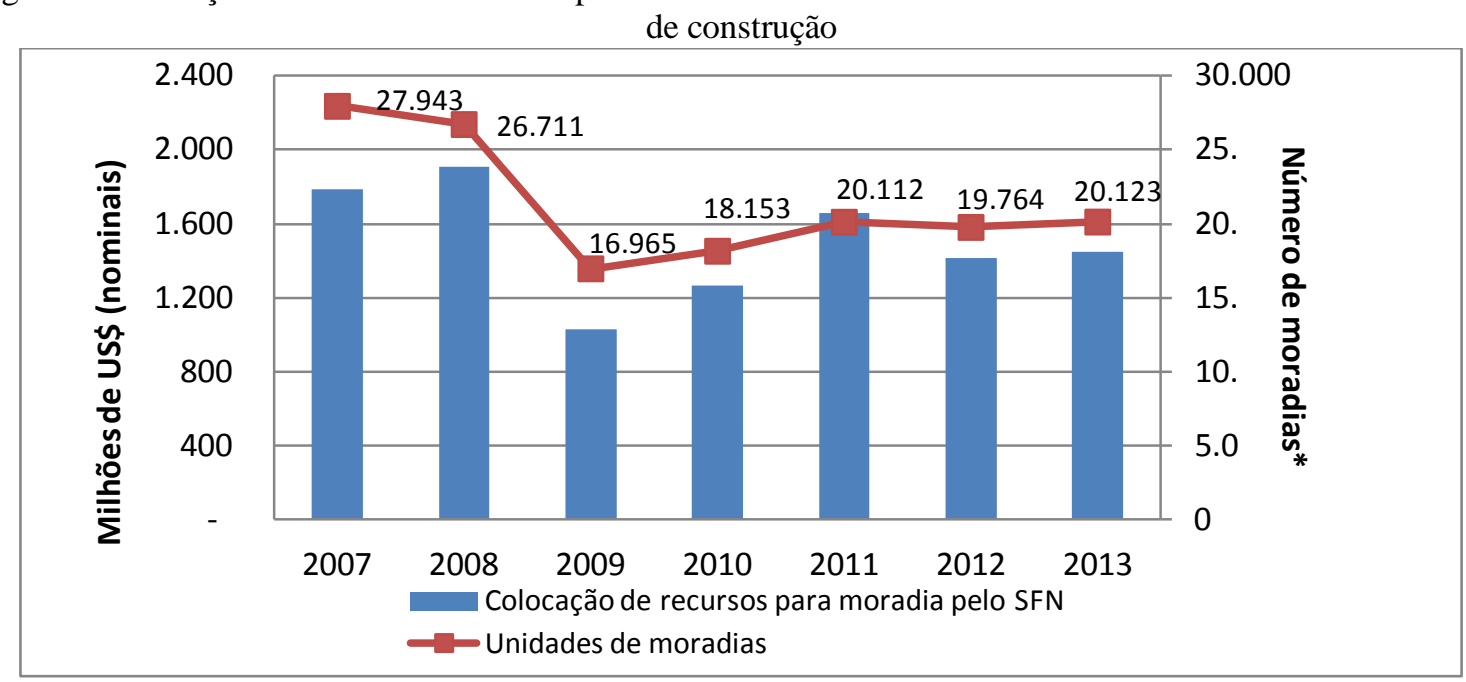

*O número de moradias corresponde ao número de “alvarás de construção” aprovados pela prefeitura, sem que isto quer dizer que a construção tem sido executada ou finalizada. A informação refere-se a construções novas e inclui moradias e apartamentos como número de moradias.

Informação original em colóns transformada a dólares a uma taxa de câmbio de 545,41 colóns.

Fonte: Elaborado pelo autor com dados do INEC e BCCR

Tabela 4. Número de moradia para 2013 segundo metros quadrados de construção

\begin{tabular}{lll}
\hline $\begin{array}{l}\text { Metros quadrados } \\
\text { construção }\end{array}$ & de & $\begin{array}{l}\text { Número de } \\
\text { obras }\end{array}$ \\
\hline
\end{tabular}

\begin{tabular}{lc}
\hline Menos de 40 & 496 \\
De 40 a menos de 70 & 11.279 \\
De 70 a menos de 100 & 2.686 \\
De 100 a menos de 150 & 2.710 \\
De 150 a menos de 200 & 1.483 \\
De 200 e mais & 1.469 \\
Total & $\mathbf{2 0 . 1 2 3}$ \\
\hline
\end{tabular}

Da figura anterior, conclui-se que aproximadamente 20.000 unidades residenciais são colocadas no mercado formal residencial costarriquenho. Este número pode manter-se, durante os próximos anos, se não ocorrerem mudanças no ambiente econômico local ou internacional.

4. No atuar da concorrência local, o setor empresarial mostrou autonomia e competências suficientes para desenvolver importantes projetos residenciais. Além disso, as empresas locais enfocam-se em estratos de rendas média-altas e altas, desenvolvendo alta 'esperteza' nestes segmentos (ver Figura 4 e Tabela 3). 


\section{Parte 3. Tomada de decisões}

Nome do entrevistado:

Principais rendas alvo dos produtos da empresa:

( ) Baixas

( ) Médias

( ) Altas

Em consideração à informação apresentada anteriormente e segundo seu critério:

A empresa estaria interessada em estudar melhor o mercado residencial da Costa Rica para ingressar nele, como por exemplo, em parceria de investimento?

\begin{tabular}{|c|c|}
\hline ) & SIM \\
\hline ) & NÃO \\
\hline ) & AINDA NÃO \\
\hline
\end{tabular}

Com base na sua decisão, responda às seguintes perguntas.

\section{Parte 4. Justificação da decisão}

\subsection{Aspectos gerais}

Com relação à qualidade da informação apresentada:

( ） É suficiente para tomar uma decisão desta importância.

( ) É insuficiente para tomar uma decisão desta importância.

( ) Além da informação apresentada, para tomar uma decisão com mais propriedade, seria necessário informação específica, customizada às exigências particulares da empresa.

( ) Indiferentemente à qualidade da informação, este tipo de estratégia difere dos atuais objetivos da empresa. 


\subsection{Aspecto do mercado residencial costarriquenho}

Quais das oportunidades e ameaças abaixo apresentadas exercem maior influência na sua decisão de estudar a possibilidade de investimento neste mercado?

Atribua pesos de 1 a 5 de acordo com o grau de importância:

1- nada importante

2- pouco importante

3- medianamente importante
4- importante

5- imprescindível

Fator

Peso

4.2.1. As oportunidades de baixo impacto (Ver sec. 2.1)

4.2.2. As oportunidades de médio impacto (Ver sec. 2.2)

4.2.3. As ameaças de baixo impacto (Ver sec. 2.4)

4.2.4. As ameaças de médio impacto (Ver sec. 2.5)

Oportunidades de alto impacto

4.2.5. Poder aquisitivo dos lares costarriquenhos (Ver ponto 1, sec. 2.3)

4.2.6. Carência residencial do país (Ver ponto 2, sec. 2.3)

4.2.7. Crescimento e características dos lares costarriquenhos (Ver ponto 3, sec. 2.3)

4.2.8. Diversas alternativas de financiamento para empresas e público (Ver ponto 4, sec. 2.3)

4.2.9. Baixas taxas de juros do mercado costarriquenho para creditos (Ver ponto 5 , sec. 2.3)

4.2.10. Incremento nas tendências de moradia para apartamentos e condomínios (Ver ponto 6, sec. 2.3)

4.2.11. Níveis de renda médios desatendidos pela concorrência local

(Ver ponto 7, sec. 2.3)

4.2.12. Características da atuação da concorrência local (Ver ponto 7, sec. 2.3)

\section{Ameaças de alto impacto}

4.2.13.O tamanho do mercado residencial (Ver ponto 1, sec. 2.6)

4.2.14. A cultura instalada (Ver ponto 1, sec. 2.6) 
4.2.15. Os entraves do sistema financeiro para créditos a empresas de real estate residencial (Ver ponto 2, sec. 2.6)

4.2.16. Os entraves do sistema financeiro para créditos de moradia própria (Ver ponto 2, sec. 2.6)

4.2.17. Pouca ou carência de poupança acumulada pelas famílias costarriquenhas (Ver ponto 2, sec. 2.6)

4.2.18. Diminuição dos recursos colocados pelos bancos para construção de moradia (Ver ponto 3, sec. 2.6)

4.2.19. Autonomia do setor empresarial local de real estate residencial (Ver ponto 4 , sec. 2.6)

4.2.20.Domínio das rendas médias-altas e altas pela concorrência local (Ver ponto 4, sec. 2.6)

4.2.21. Como considera o mercado residencial da Costa Rica para a empresa (ou empresas internacionais)?

Nada atrativo Pouco atrativo Medianamente Atrativo Muito atrativo atrativo

Atrativo

\subsection{Aspectos internos da empresa: Com base em sua decisão, responda as seguintes perguntas referentes à empresa.}

\subsubsection{Marque com um (X) quais dos seguintes atributos presentes na empresa ajudariam ao sucesso neste novo mercado.}

Capacidade de criar novas competências dependendo das condições do mercado e da estratégia implementada.

A empresa desenvolve competências que são refletidas em seus produtos no mercado local, mostrando um atuar diferenciado à concorrência.

A empresa desenvolve boas relações com parceiros externos.

A empresa possui parceiros econômicos interessados em diversificar seus investimentos em mercados internacionais.

Entendimento dos ciclos e processos do mercado local, refletindo um adequado planejamento, desenho e marketing do produto, cumprindo as expectativas dos clientes.

A empresa responde adequadamente às ameaças externas com sua estrutura organizacional e suas estratégias empresariais adaptáveis. 
A empresa pode reconhecer o risco de seus investimentos, antes e durante cada ciclo de investimento/retorno.

A empresa possui boa gestão dos recursos financeiros na área contábil, de finanças corporativas e tributos.

A empresa possui competências nas áreas de project e construction management.

Recurso humano, valores e uma filosofia empreendedora, capaz de enfrentar novos desafios como a internacionalização da companhia.

Plataforma tecnológica capaz de aproveitar as inovações desta área.

Habilidades para prestação de serviços em arenas internacionais: gerencia com domínio de outras línguas e conhecimento de finanças e economia internacional.

\subsubsection{Marque com um (X) quais das seguintes condições da empresa} dificultariam seu desenvolvimento no mercado da Costa Rica:

A cultura empresarial da companhia possui muitos traços próprios da cultura "regional", que interferem no desenvolvimento das atividades de negócios com pessoas de outros países e culturas.

A empresa nunca interagiu com empresas estrangeiras no desenvolvimento de seus negócios.

A empresa apresenta uma cultura organizacional fechada, sem desejos de mudanças ou exploração de novos mercados.

A empresa conta com uma estrutura administrativa rígida, desenhada unicamente para seu nicho de atuação.

A empresa conta com sistemas de controle familiar, mais informal e baseado nas relações pessoais.

A empresa conta com sistemas de controle burocráticos, baseados em regras e normas rígidas.

A empresa não possui procedimentos formalizados e padronizados que puderem ser replicados no estrangeiro por subsidiárias.

Recurso econômico limitado ou insuficiente para internacionalizar a empresa. 
A empresa não consegue desenvolver novas competências, a não ser a altos preços. Especialmente nos modelos de parceiras e outras alianças estratégicas.

A empresa carece de algumas competências básicas específicas das empresas de real estate residencial.

\section{Outras observações:}




\subsection{APENDICE B - Documento para a entrevista às empresas de real estate residencial Resultados das entrevistas às empresas brasileiras de real estate residencial: forças e ameaças}

Tabela B.1 - Forças das empresas entrevistadas em processos de internacionalização

\begin{tabular}{|c|c|}
\hline $\begin{array}{l}\text { 4.3.1. Atributos presentes na empresa ajudariam ao sucesso } \\
\text { neste novo mercado }\end{array}$ & $\begin{array}{l}\text { Número de } \\
\text { empresas com esta } \\
\text { força }\end{array}$ \\
\hline $\begin{array}{l}\text { Capacidade de criar novas competências dependendo das } \\
\text { condições do mercado e da estratégia implementada. }\end{array}$ & 7 \\
\hline $\begin{array}{l}\text { A empresa desenvolve competências que são refletidas em seus } \\
\text { produtos no mercado local, mostrando um atuar diferenciado à } \\
\text { concorrência. }\end{array}$ & 5 \\
\hline A empresa desenvolve boas relações com parceiros externos. & 5 \\
\hline $\begin{array}{l}\text { A empresa possui parceiros econômicos interessados em } \\
\text { diversificar seus investimentos em mercados internacionais. }\end{array}$ & 3 \\
\hline $\begin{array}{l}\text { Entendimento dos ciclos e processos do mercado local, refletindo } \\
\text { um adequado planejamento, desenho e marketing do produto, } \\
\text { cumprindo as expectativas dos clientes. }\end{array}$ & 7 \\
\hline $\begin{array}{l}\text { A empresa responde adequadamente às ameaças externas com } \\
\text { sua estrutura organizacional e suas estratégias empresariais } \\
\text { adaptáveis. }\end{array}$ & 4 \\
\hline $\begin{array}{l}\text { A empresa pode reconhecer o risco de seus investimentos, antes } \\
\text { e durante cada ciclo de investimento/retorno. }\end{array}$ & 8 \\
\hline $\begin{array}{l}\text { A empresa possui boa gestão dos recursos financeiros na área } \\
\text { contábil, de finanças corporativas e tributos. }\end{array}$ & 8 \\
\hline $\begin{array}{l}\text { A empresa possui competências nas áreas de project } \mathrm{e} \\
\text { construction management. }\end{array}$ & 9 \\
\hline $\begin{array}{l}\text { Recurso humano, valores e uma filosofia empreendedora, capaz } \\
\text { de enfrentar novos desafios como a internacionalização da } \\
\text { companhia. }\end{array}$ & 4 \\
\hline $\begin{array}{l}\text { Plataforma tecnológica capaz de aproveitar as inovações desta } \\
\text { área. }\end{array}$ & 6 \\
\hline $\begin{array}{l}\text { Habilidades para prestação de serviços em arenas internacionais: } \\
\text { gerencia com domínio de outras línguas e conhecimento de } \\
\text { finanças e economia internacional. }\end{array}$ & 3 \\
\hline
\end{tabular}


Tabela B.2 - Fraquezas das empresas entrevistadas em processos de internacionalização

\begin{tabular}{|l|c|}
\hline $\begin{array}{l}\text { 4.3.2. Condições da empresa dificultariam seu desenvolvimento } \\
\text { no mercado da Costa Rica }\end{array}$ & $\begin{array}{l}\text { Número de } \\
\text { empresas com esta } \\
\text { fraqueza }\end{array}$ \\
\hline $\begin{array}{l}\text { A cultura empresarial da companhia possui muitos traços próprios } \\
\text { da cultura "regional", que interferem no desenvolvimento das } \\
\text { atividades de negócios com pessoas de outros países e culturas. }\end{array}$ & $\mathbf{2}$ \\
\hline $\begin{array}{l}\text { A empresa nunca interagiu com empresas estrangeiras no } \\
\text { desenvolvimento de seus negócios. }\end{array}$ & $\mathbf{2}$ \\
\hline $\begin{array}{l}\text { A empresa apresenta uma cultura organizacional fechada, sem } \\
\text { desejos de mudanças ou exploração de novos mercados. }\end{array}$ & $\mathbf{3}$ \\
\hline $\begin{array}{l}\text { A empresa conta com uma estrutura administrativa rígida, } \\
\text { desenhada unicamente para seu nicho de atuação. }\end{array}$ & $\mathbf{2}$ \\
\hline $\begin{array}{l}\text { A empresa conta com sistemas de controle familiar, mais informal } \\
\text { e baseado nas relações pessoais. }\end{array}$ & $\mathbf{2}$ \\
\hline $\begin{array}{l}\text { A empresa conta com sistemas de controle burocráticos, baseados } \\
\text { em regras e normas rígidas. }\end{array}$ & $\mathbf{2}$ \\
\hline $\begin{array}{l}\text { A empresa não possui procedimentos formalizados e } \\
\text { padronizados que puderem ser replicados no estrangeiro por } \\
\text { subsidiárias. }\end{array}$ & $\mathbf{4}$ \\
\hline $\begin{array}{l}\text { Recurso econômico limitado ou insuficiente para internacionalizar } \\
\text { a empresa. }\end{array}$ & $\mathbf{2}$ \\
\hline $\begin{array}{l}\text { A empresa não consegue desenvolver novas competências, a não } \\
\text { ser a altos preços. Especialmente nos modelos de parceiras e } \\
\text { outras alianças estratégicas. }\end{array}$ & $\mathbf{1}$ \\
\hline $\begin{array}{l}\text { A empresa carece de algumas competências básicas específicas } \\
\text { das empresas de real estate residencial. }\end{array}$ & \\
\hline
\end{tabular}




\section{ANEXO}

\subsection{ANEXO A - Empresas de capital aberto}

Aproveitou-se da dissertação de Souza (2011) o detalhe da experiência de diversificação de produtos e de mercados realizada por várias empresas entrevistadas para este trabalho, entre os anos 2007-2010. Utilizou-se a secção 7.Resultados, da página 70 à 134 .

\subsection{EMPRESAS}

\subsubsection{CCDI}

A Camargo Corrêa Desenvolvimento Imobiliário S.A (CCDI) foi fundada em 1996 com o objetivo de gerir os ativos imobiliários do grupo Camargo Corrêa. A partir do início da década de 2000, o grupo passou a utilizá-la como plataforma de investimento em empreendimentos imobiliários residenciais e comerciais na cidade de São Paulo, estruturandoa para as atividades de desenvolvimento, incorporação, construção e comercialização de empreendimentos. (CCDI, 2007)

Conforme índices e informações apresentadas na Tabela 3, no período 2005 a 2010 a CCDI saiu de uma posição de elevada exposição ao mercado da cidade de São Paulo e ao segmento de alta renda, para uma empresa com um portfólio de produtos diversificado, com maior exposição ao segmento econômico e atuação concentrada no estado de São Paulo.

Para a entrada no segmento econômico e expansão geográfica para os municípios do interior do estado de São Paulo, a empresa optou pelo modelo de negócio de aquisição, ao adquirir gradativamente participação na empresa HM Engenharia e Participações.

Para a entrada em novos estados, a empresa optou pela realização de parcerias com empresas de conhecimento local. 
Entre 2002 a 2005 a empresa focou suas atividades no município de São Paulo e nos segmento residencial de alto padrão.

Em 2006 a empresa iniciou seu processo de diversificação ao desenvolver empreendimento comercial no mercado da cidade do Rio de Janeiro, em sociedade com a Tishman Speyer, parceiro com tradição no segmento de lajes corporativas.

No ano de 2007, a empresa intensificou sua estratégia de expansão geográfica e de produtos. Para atendimento da primeira, firmou parceria com a empresa Lix da Cunha, com o objetivo de promover empreendimentos no município de Campinas e região lindeira. Como estratégia de entrada no segmento econômico e popular, adquiriu o controle da empresa HM Engenharia e Participações, cuja presença de escritórios nas regiões de Barretos e Campinas também facilitou o processo de expansão geográfica. Como resultado, em 2007 a empresa lançou no mercado produtos para diferentes segmentos de renda, no entanto, sua exposição permaneceu majoritariamente no segmento de média-alta renda. Quanto à sua atuação geográfica, apesar dos lançamentos realizados no estado do Rio de Janeiro, a empresa ainda possuía elevada concentração no estado de São Paulo.

O ano de 2008 consolidou a estratégia da empresa no segmento econômico, passando a representar $73 \%$ do portfólio de lançamentos da empresa, em volume esperado de vendas. A empresa passou a deter $100 \%$ do capital social da HM, e elevou a participação dos segmentos de menor poder aquisitivo em relação aos segmentos de média-alta e alta renda.

No ano de 2009 a empresa ampliou sua expansão geográfica ao realizar lançamento no mercado da cidade de Curitiba. A empresa fez uso de competências e recursos próprios para a formatação e desenvolvimento do projeto, no entanto, firmou parceria com empresa local para a atividade de construção.

No ano de 2010, com o objetivo de dar continuidade ao crescimento almejado, a empresa firmou acordos operacionais com três empresas: com a incorporadora Kallas, o objetivo de agregar maior volume de empreendimentos na cidade de São Paulo e litoral do estado; com a JL construções o desenvolvimento de empreendimentos na cidade de Curitiba; e com a InterRio a entrada no estado do Rio de Janeiro, ocorrida por meio de empreendimento na cidade de Macaé. 


\subsubsection{CYRELA}

A Cyrela Brazil Realty é uma das maiores e mais tradicionais empresas do setor da construção civil brasileira, sendo a empresa com maior volume de lançamentos no período 2005-2010 em valor geral de venda dos empreendimentos, segundo dados levantados pelo próprio autor.

Conforme índices e informações apresentadas no Tabela 4, no período 2005 a 2010 a Cyrela saiu de uma empresa de concentração estadual e diversificação dominante de produtos, com maior exposição no segmento de média-alta renda, para uma empresa de atuação nacional e portfólio diversificado de produtos.

Como estratégia de expansão de produtos, a empresa fez uso gradual de parcerias e joint ventures, de maneira a propiciar o desenvolvimento da plataforma Living, construtora própria especializada na produção de unidades destinadas aos segmentos econômico e popular. As parcerias tiveram como objetivo realizar os primeiros projetos destinados ao publico de menor poder aquisitivo, através da co-incorporação pontual em nível das sociedades de propósito específico dos empreendimentos. Entre as parcerias realizadas, destacam-se as iniciadas em 2006 com as empresas Plano e Plano, Goldfarb e Concima.

Posteriormente, a parceria realizada com a Plano e Plano foi transformada numa joint venture de participação igualitária entre as organizações, cujo modelo permanece até a data da presente dissertação.

A empresa Goldfarb, atualmente pertencente à empresa concorrente PDG, conforme será detalhado em capítulo posterior, permanece como uma empresa parceira com a realização pontual de empreendimentos.

A empresa Concima foi adquirida pela Cyrela no ano de 2008, e seus recursos absorvidos pela construtora Living.

Em 2007 foram realizadas joint ventures com as empresas Cury e Tecnum, cuja aliança permanece até a data da presente dissertação e fazem parte do modelo de desenvolvimento de produtos para os segmentos popular e econômico. 
Como estratégia de expansão geográfica, a Cyrela fez uso de diversos modelos de negócios. Para os estados de Santa Catarina e região Centro-Oeste, Norte e Nordeste do país, a Cyrela firmou parcerias com as empresas Cota empreendimentos imobiliários, Santa Izabel, MAC, Marquise, Incortel, Agra, EBM construtora, Doria construtora e outras. Por meio das joint ventures com as construtoras Lider e Andrade Mendonça, a Cyrela entrou nos mercados, respectivamente, de Minas Gerais, Distrito Federal e Bahia.

Como estratégia de entrada no mercado da região Sul e expansão para o segmento econômico, a empresa adquiriu o controle da empresa Goldsztein, antes uma joint venture entre as companhias.

Segundo informações disponíveis no prospecto de emissão primária de ações (CYRELA, 2006), a empresa considera as parcerias um meio de fazer uso das competências de mercado, de produtos e da marca do parceiro, que, aliado à escala e ao conhecimento financeiro da Cyrela, permite a entrada em novos segmentos e mercados de maneira eficiente.

\subsubsection{COMPANY, BRASCAN E BROOKFIELD}

A empresa Brookfield é resultado da fusão entre as empresas Brascan e Company e, posteriormente, da aquisição da empresa MB Engenharia. O grupo fez uso de aquisições para crescer e expandir seus negócios para outros mercados.

Entre 2005 e 2007, as empresas Company e Brascan eram relativamente equivalentes em termos de geração de receita, volume de empreendimentos e concentrações de mercados e produtos. Enquanto a primeira possuía elevada exposição na cidade de São Paulo e nos segmentos de média e alta renda, a Brascan, além da exposição ao mercado de alta renda, possuía significativa concentração nos mercados das cidades do Rio de Janeiro e São Paulo.

Ambas as empresas abriram capital na BM\&Fbovespa em 2006, e possuíam como estratégia declarada a diversificação de produtos e mercados. 
Em 2007, a Company iniciou sua estratégia de expansão geográfica ao realizar poucos lançamentos em cidades do interior do estado de São Paulo e da região metropolitana da capital, passando de uma atuação municipal para regional. Simultaneamente, ampliou o seu portfólio de produtos ao realizar lançamentos para os segmentos econômico e escritórios, ambos por meio de incorporação própria.

Em 2008, as empresas Brascan e Company fundiram suas operações. Meses depois, com o objetivo de expandir a atuação da organização para outros mercados do país, o grupo adquiriu o controle da MB engenharia, empresa com atuação na região do centro-oeste brasileiro.

Em 2009, o grupo optou por reunir na marca Brookfield Incorporações todas as suas marcas existentes, com o objetivo de reforçar a operação sob uma plataforma única e integrada.

Para a entrada nos segmentos popular e econômico, a Brookfield optou pelo modelo de incorporação própria, ao desenvolver competências de engenharia e produtos por meio de recursos internos a companhia.

\subsubsection{EZTEC}

A empresa Eztec Empreendimentos e Participações S.A possuía em 2005 uma concentração no mercado de alta renda do município de São Paulo. Ao longo do período 2005-2010, a empresa ampliou a receita em sete vezes e, apesar da companhia ter expandido suas atividades para outros municípios da Região Metropolitana de São Paulo e Vale do Paraíba Paulista, manteve atuação predominante no capital do estado.

Em 2007 a empresa firmou parceria com as empresas Honduras, M\&M e Genea com o objetivo de realizar lançamentos no segmento de baixa renda. Ao contrário da maioria das empresas concorrentes, objeto de estudo da presente dissertação, a Eztec mantinha como estratégia o segmento de média-alta renda, porém com a intenção de realizar lançamentos nos segmentos de menor poder aquisitivo, por meio de parceiros, com o objetivo de laboratório, aprender e absorver as competências necessárias para o novo produto. (EZTEC, 2008). 
Em 2008, em parceria com a empresa Genea, a Eztec entrou no mercado da cidade de Mogi das Cruzes com empreendimento destinado ao segmento econômico.

Em 2009, a empresa ampliou a participação de lançamentos voltados para o segmento comercial e de alta renda; todos, no entanto, concentrados na Região Metropolitana de São Paulo.

No ano de 2010 a empresa manteve a sua estratégia de concentração no município de São Paulo e região lindeira, e ampliou sua participação no segmento econômico. Apesar das movimentações, a empresa manteve seu nível de diversificação geográfica como de atuação regional e portfólio de produtos concentrado.

As parcerias realizadas para a entrada no segmento de baixa renda e outros municípios do Estado de São Paulo, tento em vista o objetivo inicial de laboratório, não foram relevantes em volume estimado de venda em relação ao portólio total de lançamentos da empresa aproximadamente $4 \%$ apenas -, configurando a estratégia de crescimento da empresas como penetração de mercado, com o objetivo de crescer predominantemente para produtos e mercados já operados pela empresa, sem o afastamento de suas competências principais. 